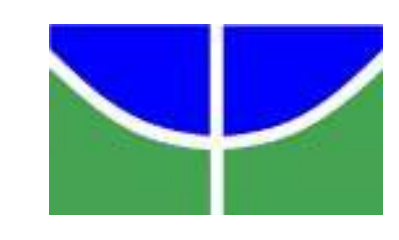

UNIVERSIDADE DE BRASÍLIA

INSTITUTO DE LETRAS DEPARTAMENTO DE LÍNGUAS ESTRANGEIRAS E TRADUÇÃO - LET PROGRAMA DE PÓS-GRADUAÇÃO EM LINGUÍSTICA APLICADA - PPGLA

THALITA DA ROCHA SOARES FERREIRA

A AVALIAÇÃO NO ENSINO DE INGLÊS COMO LE: CRENÇAS, REFLEXÕES E RESSIGNIFICAÇÃO

\author{
BRASÍLIA - DF \\ NOVEMBRO/2015
}


THALITA DA ROCHA SOARES FERREIRA

A AVALIAÇÃO NO ENSINO DE INGLÊS COMO LE:

CRENÇAS, REFLEXÕES E RESSIGNIFICAÇÃO

Dissertação de Mestrado apresentada ao Programa de Pós-Graduação em Linguística Aplicada da Universidade de Brasília, como requisito parcial à obtenção do título de Mestre em Linguística Aplicada.

Orientador: Prof. Dr. Yûki Mukai

$$
\text { BRASÍLIA - DF }
$$

NOVEMBRO/2015 


\section{REFERÊNCIA BIBLIOGRÁFICA E CATALOGAÇÃO}

FERREIRA, Thalita da Rocha Soares. A AVALIAÇÃO NO ENSINO DE INGLÊS COMO LE: CRENÇAS, REFLEXÕES E RESSIGNIFICAÇÃO. Brasília: Departamento de Línguas Estrangeiras e Tradução, Universidade de Brasília, 2015, 139 f. Dissertação de mestrado.

Documento formal, autorizando a reprodução desta dissertação de mestrado para empréstimo ou comercialização, exclusivamente para fins acadêmicos, foi passado pela autora à Universidade de Brasília e acha-se arquivado na Secretaria do Programa. A autora reserva para si os outros direitos autorais, de publicação. Nenhuma parte desta dissertação de mestrado pode ser reproduzida sem a autorização por escrito da autora. Citações são estimuladas, desde que citada a fonte. 
THALITA DA ROCHA SOARES FERREIRA

\title{
A AVALIAÇÃO NO ENSINO DE INGLÊS COMO LE: CRENÇAS, REFLEXÕES E RESSIGNIFICAÇÃO
}

\begin{abstract}
Dissertação de Mestrado apresentada ao Programa de Pós-Graduação em Linguística Aplicada da Universidade de Brasília, como requisito parcial à obtenção do título de Mestre em Linguística Aplicada.
\end{abstract}

Aprovada por:

Prof. Dr. Yûki Mukai - Universidade de Brasília

(Orientador)

Profa. Dra. Mariney Pereira Conceição - Universidade de Brasília

(Examinador Interno)

Profa. Dra. Ana Maria Ferreira Barcelos - Universidade Federal de Viçosa (Examinador Externo)

Profa. Dra. Gladys Plens de Quevedo Pereira de Camargo - Universidade de Brasília (Examinador Suplente) 
À minha família, pelo amor que recebo diariamente, e para que lembremos sempre que nada é impossível aos que buscam com esforço...e de todo o coração. 


\section{AGRADECIMENTOS}

Primeiramente, meus agradecimentos se voltam para Deus, por ter me proporcionado a oportunidade de concretizar o sonho do Mestrado, fazendo-me observar sua misericórdia em cada novo capítulo finalizado, concedendo-me ânimo e vontade para trilhar os caminhos até o final do programa.

Em seguida, agradeço carinhosamente ao meu amado marido, por ter se transformado em leitor e revisor de texto, por pacientemente abrir mão de noites e finais de semana em prol da minha pesquisa, ajudando-me em todos os detalhes durante esses dois anos.

Agradeço também ao meu querido orientador, o Professor Doutor Yûki Mukai, cuja disposição, profissionalismo, comprometimento e ética ecoam em todas as páginas do meu trabalho. Seu apoio, ânimo e paciência foram inspiração para mim. Sinto-me privilegiada e honrada por ter sido orientada por um pesquisador brilhante como você.

Agradeço ainda à estimada Professora Doutora Mariney Conceição, por ter influenciado e instigado a pesquisadora que existe em mim. Muito obrigada pela sua presença e estímulo, os quais remontam a muito antes desta pesquisa ser idealizada e concebida.

Agradeço às Professoras Doutoras Gladys Quevedo Camargo e Ana Maria Barcelos, cujos trabalhos inspiraram profundamente esta pesquisa e com as quais eu tenho o privilégio e o prazer de contar como examinadoras deste estudo.

Agradeço também à Professora Doutora Vanessa Borges, pois foram as suas aulas que trouxeram um norte para a minha pesquisa. Obrigada pelas considerações e carinho dispensados a mim em todos os momentos que circundaram este estudo.

Por fim, agradeço a todos os familiares e amigos que de alguma forma contribuíram para a realização deste trabalho. 


\section{RESUMO}

Esta pesquisa tem por objetivo investigar as crenças de um professor de língua inglesa como língua estrangeira no tocante à avaliação de seus alunos, visto que 0 que se observa hoje no contexto de ensino de língua estrangeira no Brasil, primordialmente no que concerne à avaliação, é uma perpetuação de abordagens tradicionais e técnicas sistêmicas, as quais são muitas vezes baseadas unicamente nas aprendizagens anteriores dos discentes e não contemplam as reais funções da avaliação (BATISTA, 2013; LUCKESI, 2001; LOPES, 2002; PORTO, 2003; SCARAMUCCI 2006; SUASSUNA e BEZERRA, 2010), pois continuam a tentar quantificar resultados através do uso exclusivo de métodos somativos, mantendo o foco avaliativo no produto, e não no processo de ensino e aprendizagem (BARATA, 2006; SCARAMUCCI, 1997). Assim, esta pesquisa, desenvolvida na forma de um estudo de caso interventivo de bases qualitativas, tem por finalidade identificar as crenças de um professor de inglês no que tange à avaliação, observando de que forma as mesmas influenciam a sua prática, além de entender como momentos reflexivos podem propiciar o início da ressignificação de crenças e, por fim, analisar o impacto da presente pesquisa sobre as crenças e a prática deste professor. Os dados analisados foram colhidos através de uma narrativa, de uma entrevista semiestruturada, observações de aulas com gravações em áudio e em vídeo, além das notas de campo da pesquisadora, duas sessões de discussão e duas sessões de visionamentos. Os resultados obtidos demonstram que o participante do estudo possui crenças que concernem não apenas ao seu próprio agir e pensar sobre avaliação, mas também à forma que acredita que seus alunos concebem estes construtos. Além disso, a prática do professor reflete as suas crenças sobre avaliação, demonstrando acentuada conexão entre crenças e ações. Ao término do estudo, foi possível observar o intenso processo reflexivo no qual o professor se encontra, o qual se espelhou tanto na tentativa de implementação de modelos alternativos de avaliação na sua prática discente, quanto na mudança de discurso do professor em relação a alguns aspectos da avaliação. Assim, é possível concluir que durante a pesquisa o professor teve a oportunidade de refletir a respeito da sua própria prática avaliativa, o que propiciou uma abertura para modelos diferenciados de avaliação e o início do processo de ressignificação de algumas crenças sobre avaliação.

PALAVRAS-CHAVE: Crenças de professores de LE. Avaliação. Ensinoaprendizagem de inglês como LE. Intervenção. 


\begin{abstract}
This research aims to investigate the beliefs of one teacher, regarding the evaluation applied upon his students, since what is widely seen, throughout the foreign language teaching context in Brazil, primarily regarding the evaluation, is a perpetuation of traditional approaches and systemic techniques, which do not embrace the actual principles and functions of evaluation (BATISTA, 2013; LUCKESI, 2001; LOPES, 2002; PORTO, 2003; SCARAMUCCI 2006; SUASSUNA \& BEZERRA, 2010) as they continue trying to quantify results through the exclusive use of somative methods, maintaining the evaluation focus on the product, not on the process itself (BARATA, 2006; SCARAMUCCI, 1997). Therefore, this research, shaped as a qualitative and interventional case study, aims to identify the beliefs of an English teacher regarding the evaluation system, observing how these beliefs can influence his practice, besides trying to understand how moments of reflection can propitiate the beginning of the ressignification of beliefs and also analyzing the impact that this study has upon the beliefs and practice of the participant. The data analyzed were collected through a narrative, an interview, class observations together with their recording in audio and in video, field notes, two discussion sessions and two reflective video sessions. The drawn results show that the participant has beliefs concerning not only his own thoughts and acts about evaluation, but also the way he believes students conceive evaluation. Besides, the beliefs of the teacher can be clearly seen in his practice, showing a strong relation between beliefs and actions. At the end of this study, it was possible to observe the intense process of reflection through which the teacher was going. The reflex of this process could be seen in his attempts to implement alternative models of evaluation, as well as in his change of discourse related to the subject. Thus, it is possible to conclude that during this research the teacher had the opportunity to reflect about his own evaluative practice, what provided him with an opening for different perspectives of evaluation, enabling him to start the process of ressignification of some beliefs.
\end{abstract}

KEY WORDS: Beliefs of foreign language teachers. Assessment. Teaching and learning process of English as a second language. Intervention. 


\section{LISTA DE FIGURAS}

FIGURA 01: DIAGRAMA ANALÍTICO DOS PROCESSOS DE RESSIGNIFICAÇÃO DE CRENÇAS E MUDANÇA DE AÇÕES DO PROFESSOR

FIGURA 02: ATIVIDADES AVALIATIVAS DO PRIMEIRO BIMESTRE

FIGURA 03: REDAÇÕES

FIGURA 04: AVALIAÇÃO DO SEGUNDO BIMESTRE

FIGURA 05: SÍNTESE DE INDÍCIOS DE RESSIGNIFICAÇÃO E 100 PERMANÊNCIA DE CRENÇAS 


\section{LISTA DE QUADROS}

QUADRO 01: COMPARATIVO DA CRENÇAS APRESENTADAS PELA PROFESSORA-ACADÊMICA, A RESPEITO DA AVALIAÇÃO EM LÍNGUA ESTRANGEIRA, NAS TRÊS FASES DO TRABALHO DE PESQUISA-AÇÃO

QUADRO 02: NOMENCLATURA, CICLOS E CORRESPONDÊNCIA DOS 42 CURSOS

QUADRO 03: ETAPAS DA PESQUISA

QUADRO 04: PROCEDIMENTOS PARA A ANÁLISE DOS DADOS

QUADRO 05: SÍNTESE DAS CRENÇAS

QUADRO 06: CRITÉRIOS PARA AVALIAÇÃO DE APRESENTAÇÕES ORAIS

QUADRO 07: CRITÉRIOS PARA AVALIAÇÃO DE REDAÇÕES

QUADRO 08: CORRECTION SYMBOLS

QUADRO 09: CRITÉRIOS PARA CORREÇÃO DA ANÁLISE ESCRITA DO LIVRO

QUADRO 10: AVALIAÇÃO (APRESENTAÇÕES ORAIS)

QUADRO 11: SÍNTESE DE CRENÇAS E SUAS INFLUÊNCIAS 


\section{LISTA DE ABREVIATURAS E SIGLAS}

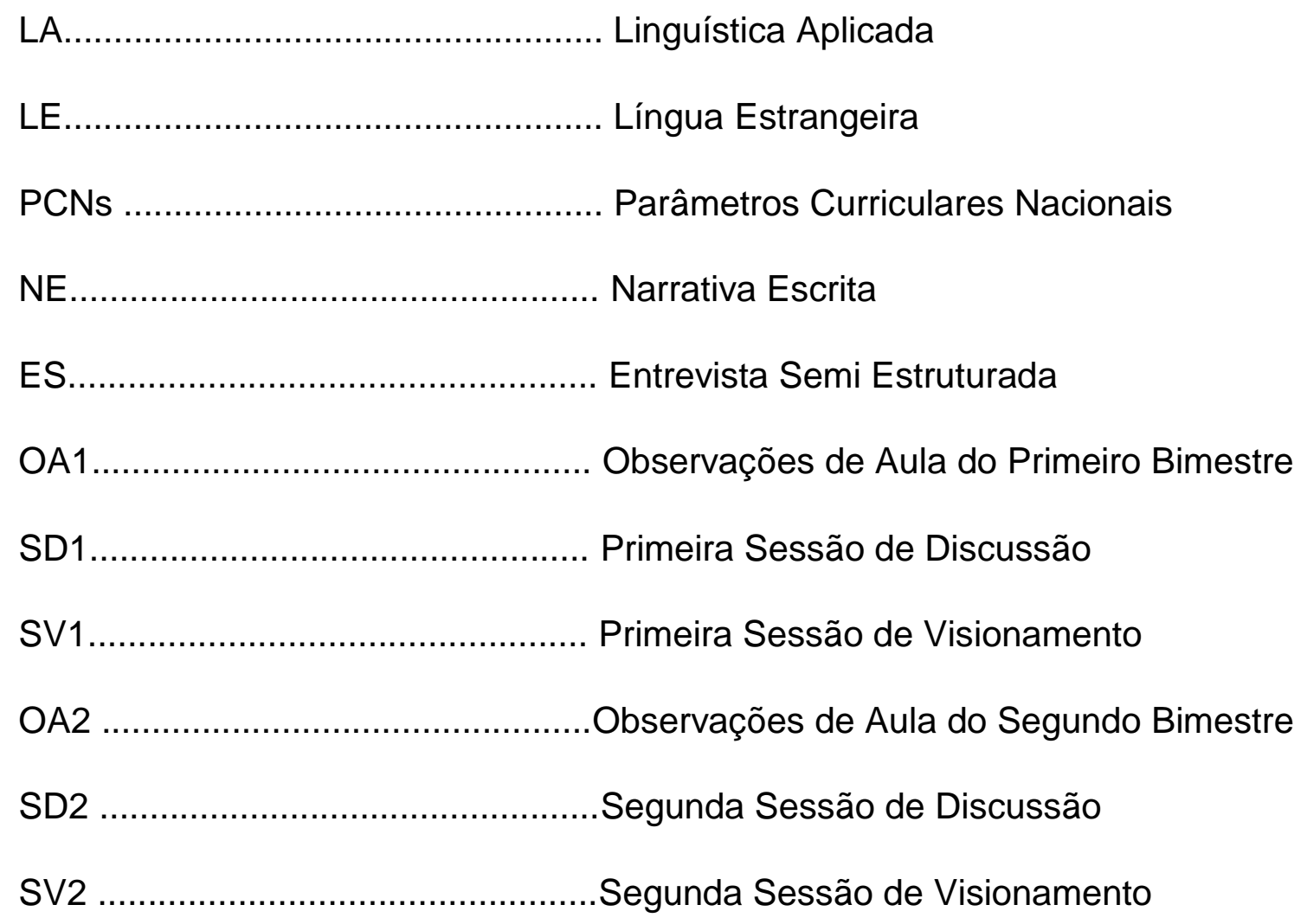




\section{CONVENÇÕES PARA TRANSCRIÇÃO}

Para a transcrição dos excertos da entrevista semi estruturada, das duas sessões de discussão, das duas sessões de visionamento e dos trechos selecionados das aulas observadas, foram utilizadas as convenções que seguem, baseadas em Marcuschi (2003).

/ .................................................Truncamento ou interrupção abrupta da fala.

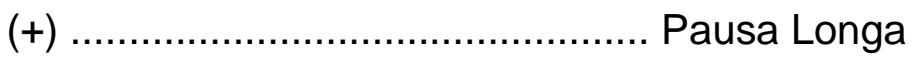

(...) ……..................................... Supressão de trechos

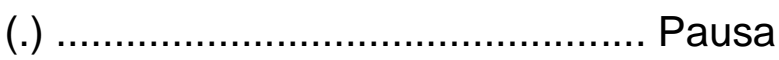

MAIÚSCULAS .............................. Entoação enfática

:: ou mais :..: ................................. Prolongamento de vogal ou consoante

? Interrogação

!

Fáticos e interjeições

$\mathrm{mhm}, \mathrm{mm}$, nhum

Pausas preenchidas, hesitação

"

Citação ou referência a outras falas.

$\left({ }^{*}\right)$ Uma palavra incompreensível

$\left({ }^{*}\right)$ Mais de uma palavra incompreensível

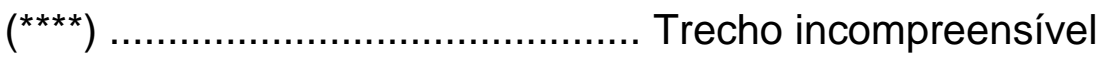

Itálico Palavras em inglês 


\section{SUMÁRIO}

1 INTRODUÇÃO

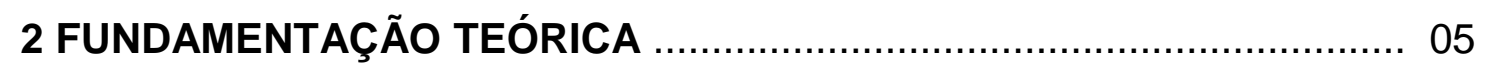

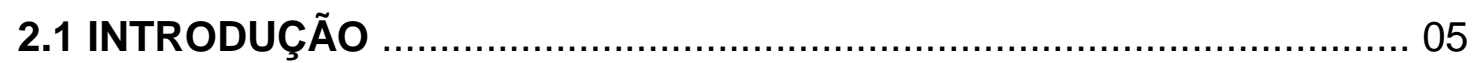

2.2 AVALIAÇÃO: ANTECEDENTES E DESDOBRAMENTOS …................ 05

2.3 O CONSTRUTO CRENÇAS NO ÂMBITO DA LA …............................. 17

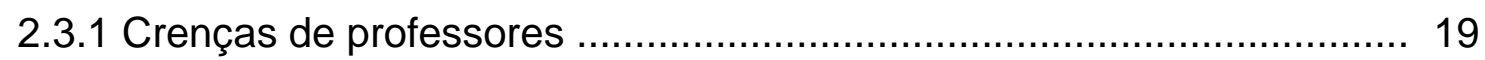

2.3.2 Crenças de professores sobre avaliação .......................................... 22

2.4 REFLEXÃO E ATITUDE: O CAMINHO PARA A RESSIGNIFICAÇÃO... 27

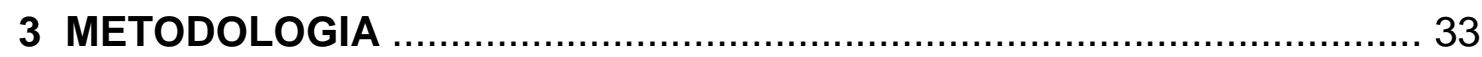

3.1 INTRODUÇÃO

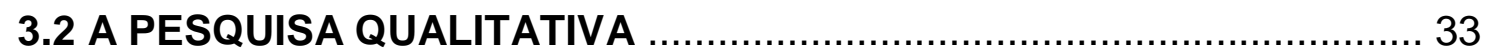

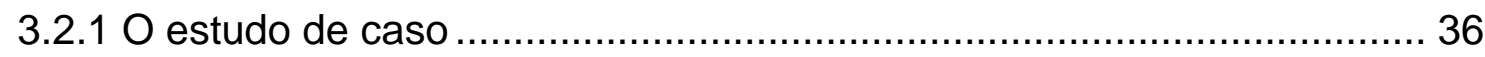

3.2.1.1 O estudo de caso interventivo ....................................................... 39

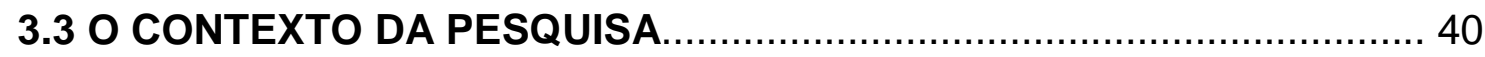

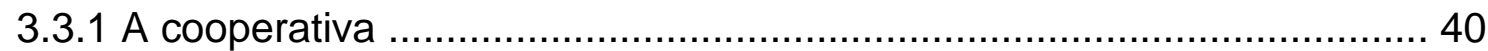

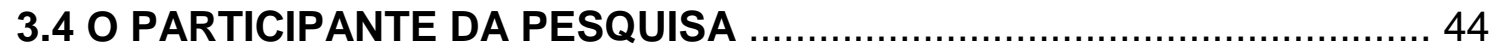

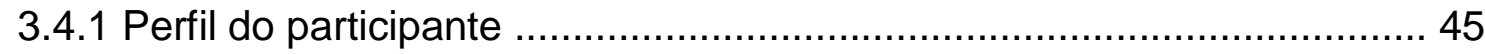

3.5 OS INSTRUMENTOS DA COLETA DE REGISTROS ….......................46

3.6 PROCEDIMENTOS PARA A COLETA DE REGISTROS …....................51

3.7 PROCEDIMENTOS PARA A ANÁLISE DOS DADOS …….................. 54

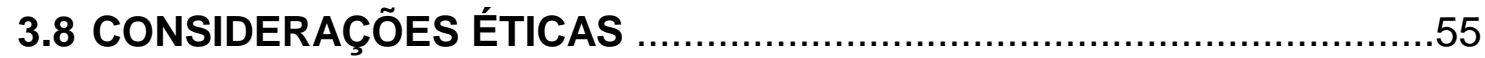

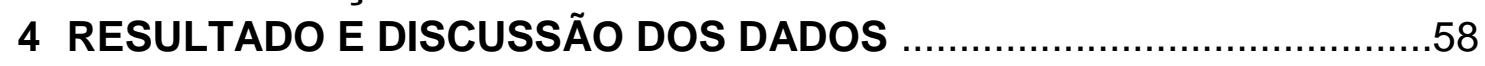

4.1 LEVANTAMENTO E DISCUSSÃO DAS CRENÇAS …............................ 59

4.1.1 Como o professor percebe suas próprias práticas avaliativas, os instrumentos avaliadores e a avaliação em si............................................ 59

4.1.2 Como o professor acredita que os alunos concebem a avaliação.......... 67

4.2 PROCESSO DE RESSIGNIFICAÇÃO DE CRENÇAS ………................. 75

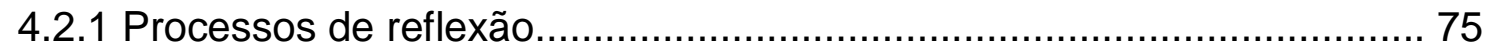

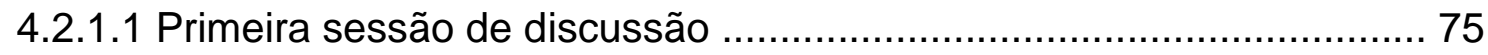

4.2.1.2 Primeira sessão de visionamento ..................................................

4.2.2 Propostas de mudança ................................................................. 79

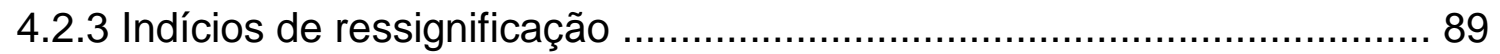

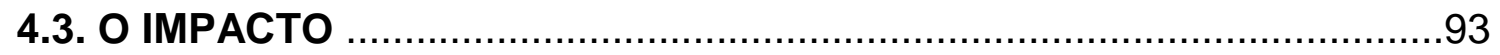

4.3.1 Orientação sobre avaliação para os novos professores...........................94 
4.3.2 A segunda sessão de discussão ...............................................95

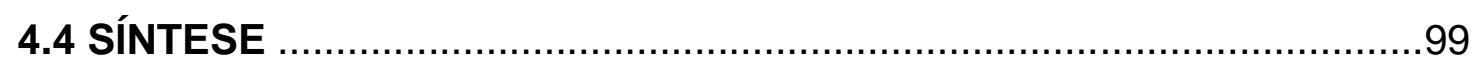

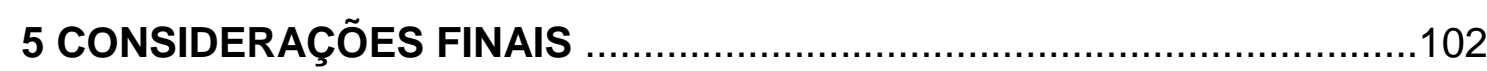

5.1 RETOMANDO OS OBJETIVOS E PERGUNTAS DE PESQUISA..........103

5.2 CONTIBUIÇÕES DO ESTUDO ..................................................... 107

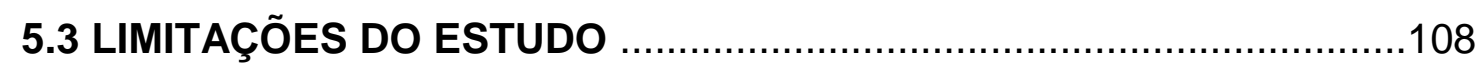

5.4 SUGESTÕES PARA FUTURAS INVESTIGAÇÕES …......................... 109

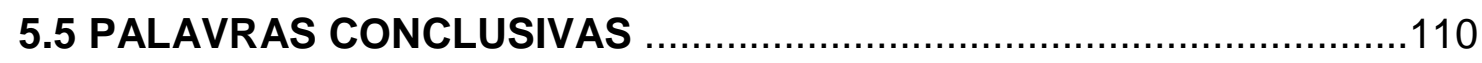

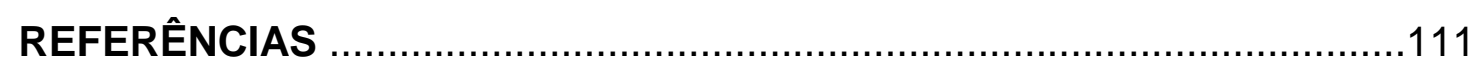

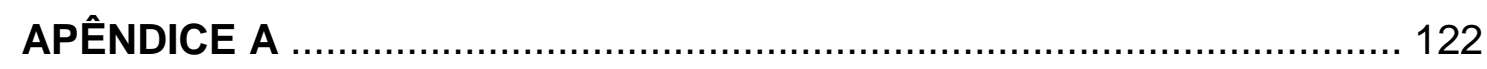

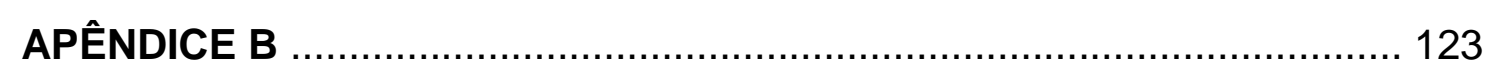

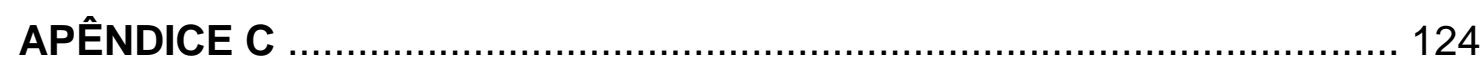

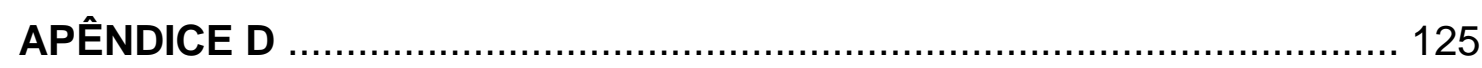




\section{INTRODUÇÃO}

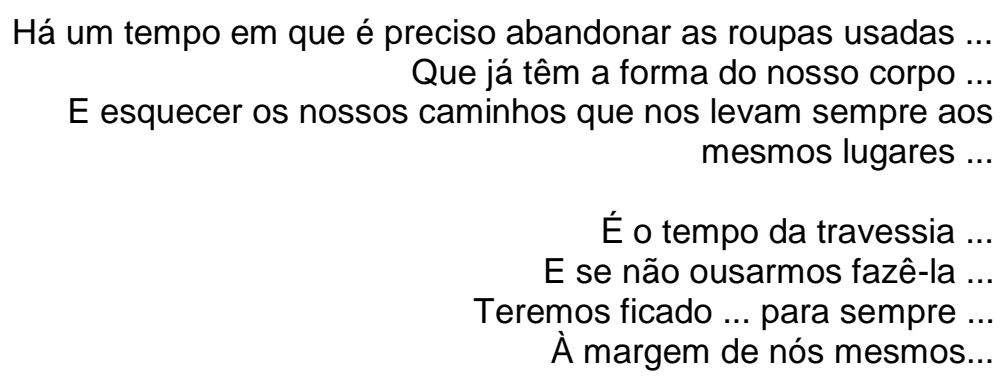

Fernando Teixeira de Andrade

Toda a vivência humana é grandemente pautada nas experiências desenvolvidas diariamente. As ações se transformam em hábitos que por sua vez viram rotina até que, em determinado momento da história, acreditamos que algumas situações existem desde sempre, imutáveis e eternas. A esta situação, o sociólogo francês Pierre Bourdieu (2003) denominou habitus, entendendo este conceito como a história que ocorreu e se repetiu inúmeras vezes, até que a sua origem tenha sido esquecida e, assim como as crenças de um povo, passou a existir no imaginário popular como absoluta, sem necessidade de reflexão ou questionamento.

Este mesmo pensamento pode ser aplicado a diversas áreas das nossas vidas, inclusive ao contexto educacional no qual estamos inseridos. Professores, alunos, pais, gestores educacionais e toda a sociedade muitas vezes aceitam o que está em vigência pela simples acomodação em relação ao que já existe, e, por vezes, pela falta de reflexão ou até mesmo orientação, percebem os caminhos trilhados pela educação atual como completos e únicos.

Entretanto, as pesquisas dentro da Linguística Aplicada, doravante LA, demonstram cada vez mais a necessidade da formação de indivíduos reflexivos, criadores e transformadores do contexto educacional no qual vivem (ARRUDA, 2008; BARCELOS, 2004; ROLIM, 1998; SCARAMUCCI, 2006). Também segundo estes estudos, a frustração com o sistema educacional, 
especificamente no tocante ao ensino de línguas, e a falta de preparo de professores, em especial no que concerne o ato de avaliar, é visível até para quem está decidido a não se importar com este cenário.

Por este motivo, o estudo do que motiva professores e alunos a agirem da forma como agem no ambiente escolar e a possibilidade de, a partir deste entendimento, observar quais são as principais falhas no processo e engendrar uma intervenção reflexiva capaz de ser uma das faíscas necessárias ao início de uma mudança no cenário educacional brasileiro é a grande motivação da presente pesquisa.

Considerando, portanto, que as crenças são elementos basilares que atuam nesta dinâmica e que um maior entendimento sobre as mesmas pode facilitar o vislumbre de estratégias para a mudança, as crenças de professores, em particular as que dizem respeito à avaliação, foi o assunto escolhido nesta pesquisa.

O interesse especial em avaliação deu-se pelo entendimento, através de leituras como Barata (2006) e Scaramucci (2007), da importância desta ao longo de todo o processo de ensino e aprendizagem de línguas, bem como da assimilação do fato de que o processo avaliativo deveria ser o ponto de partida dos programas de cursos escolares, e não o seu fim. Assim, este fenômeno se engrandeceu aos meus olhos, despertando o desejo de estudá-lo mais profundamente para, talvez, propiciar o momento de reflexão necessário para gerar alguma mudança nesta prática.

Além disso, alguns estudos sobre avaliação (ARAÚJO, 2006; BARATA, 2006; BATISTA, 2013; FERREIRA, 2009; SCARAMUCCI, 2004) apontam para o fato de que o processo avaliativo vem sendo negligenciado por parte dos professores de língua estrangeira, doravante LE, constituindo-se em um mero processo de dar notas aos alunos, ou, em última instância, na quantificação dos esforços pontuais e descontextualizados dos aprendizes. Assim, não apenas se ignora as funções básicas da avaliação (as quais serão trabalhadas detalhadamente em seção vindoura), mas também a reduz ao produto unilateral e muitas vezes arbitrário do processo de ensino e aprendizagem de LE. 
Diante do exposto e a partir da premissa de que os professores tendem a repetir na sua prática docente a forma como aprenderam o idioma (ARAÚJO, 2006; PAJARES, 1992), entender quais são as crenças dos professores no tocante à avaliação da língua inglesa, e como as mesmas refletem não apenas o que eles acreditam sobre a língua, mas também como agem e porque agem da forma que o fazem nos contextos educacionais, pode auxiliar no engendramento de estratégias que sirvam como subsídio no processo reflexivo tão necessário a todos os profissionais da educação.

Dessa forma, norteado pela necessidade de uma maior compreensão do processo de aprender e ensinar línguas, e, principalmente, em como este fomenta 0 ato de avaliar do professor, este estudo possui os seguintes objetivos:

a) identificação das crenças de professores de inglês concernentes à avaliação dos seus alunos, visando entender como as mesmas influenciam as ações dos professores em sala de aula.

b) observar de que forma momentos de reflexão poderiam abrir portas para novas perspectivas e para a ressignificação de crenças concernentes à avaliação.

c) analisar o impacto desta pesquisa sobre o professor participante e suas práticas no que concerne à avaliação.

Visando alcançar os objetivos propostos acima, pretendo responder às seguintes perguntas norteadoras:

a) Quais são as crenças do professor participante no que tange à avaliação e de que forma essas crenças se relacionam às suas tomadas de decisões em sala de aula?

b) Como momentos guiados de reflexão podem contribuir para a ressignificação de crenças?

c) Qual impacto esta pesquisa teve sobre as crenças e práticas do professor participante? 
Assim, após articular a respeito da justificativa, dos objetivos e das perguntas norteadoras desta pesquisa, discorro, na seção a seguir, o concernente às bases teóricas que alicerçam este estudo. 


\section{FUNDAMENTAÇÃO TEÓRICA}

Não é no silêncio que os homens se fazem, mas na palavra, no trabalho, na ação-reflexão.

Paulo Freire

\subsection{INTRODUÇÃO}

O presente capítulo tece um levantamento das características primordiais da avaliação, e discorre a respeito de como esta vem sendo tratada na atualidade. Em seguida, traça um breve histórico sobre a pesquisa de crenças, buscando desenvolver a base necessária para as considerações posteriores a respeito das crenças dos professores e da rede de concepções que os docentes possuem em relação às atividades avaliativas que desenvolvem no contexto educacional, bem como das crenças diretamente relacionadas a este tema, e como as mesmas podem vir a influenciar direta ou indiretamente as tomadas de decisão dos professores no momento de avaliar. Por fim, este capítulo explana a respeito da possibilidade de ressignificação de crenças, e as possíveis mudanças advindas do processo de reflexão ${ }^{1}$ entre professores, alunos e pesquisadores.

\subsection{AVALIAÇÃO: ANTECEDENTES E DESDOBRAMENTOS}

Segundo Ferreira (2009, p. 9), a avaliação é uma atividade intrínseca do ser humano, acontecendo consciente ou inconscientemente nas práticas que desenvolvemos ao longo da nossa vida. Considerando-se o cenário educacional, discutir as concepções de avaliação é basilar para o entendimento, por parte do professor, dos avanços sólidos dos seus alunos,

1 O construto reflexão adotado neste trabalho vai ao encontro das ideias explicitadas por Saviani (2000), o qual explica que o ato de reflexão se constitui na retomada, reconsideração e revisitação dos dados presentes, com o intuito de construir continuamente o significado destes. Adotamos também a postura de Gómez (1992), que argumenta que o processo reflexivo pressupõe a imersão consciente do ser no contexto da sua experiência. 
bem como das carências e necessidades a serem trabalhadas, e, por parte dos aprendizes, do despertar de um compromisso com a sua própria aprendizagem, a partir do reconhecimento de suas fraquezas ou limitações e da constatação dos seus progressos.

Ao traçarmos um breve apanhado histórico a respeito da situação da avaliação escolar no Brasil, o que percebemos é a predominância de modelos tradicionais de ensino (ALMEIDA FILHO, 1993; LUCKESI, 2001; LOPES, 2002; PORTO, 2003; SCARAMUCCI 2006; SUASSUNA e BEZERRA, 2010). Segundo Hoffman (1993), o que se encontra neste modelo avaliativo é a presença de uma avaliação quantitativa, gabaritos com respostas únicas e fechadas, médias e estatísticas que, em última instância, fomentam a promoção de alunos e escolas, ao invés de preocupar-se com a aprendizagem ocorrida durante o processo.

Assim, a literatura nos revela que a atenção dos métodos tradicionais de ensino de LE, amplamente difundidos no Brasil até o início da década de 70, encontra-se voltada essencialmente para o produto final da educação, e não para os desdobramentos ocorridos ao longo do percurso.

Sobre o assunto, Avila (2013, p.39) expõe que

\begin{abstract}
Em grande parte, as abordagens que guiaram o ensino de LE durante o século passado basearam seus pressupostos em um modelo tradicional, em que o ensino da língua baseia-se no domínio da estrutura linguística da língua alvo. No paradigma tradicional, o ensino focaliza a gramática, a aquisição de vocabulário, a tradução e exaustiva a preocupação com a forma.
\end{abstract}

Hoffman (1993) afirma ainda que o inconformismo dos professores brasileiros em relação a esta abordagem mostrou-se de forma mais acentuada na década de 70 , gerando assim a abertura necessária para os novos contornos de avaliação delineados pela visão qualitativa, a qual, segundo Avila (2013, p. 42), possui como objetivo principal "possibilitar ao aprendiz o conhecimento de como usar um idioma para atingir uma comunicação significativa", sendo o aluno o centro do processo de ensino e a interação o foco da abordagem. Assim, o aluno deixa de ser entendido como mero reprodutor das regras que Ihes foram conferidas pelo professor, e passa a ser 
enxergado como o coautor do processo de ensino-aprendizagem e responsável pelos seus desdobramentos.

Dentro deste novo paradigma, retomamos o exposto inicialmente por Ferreira (2009), segundo o qual é a partir do ato de avaliar que se propicia o momento de repensar os elementos formadores do curso, visando a melhoria do mesmo e, consequentemente, a assistência necessária aos alunos, segundo os desdobramentos percebidos por todos os envolvidos no decorrer do processo. Para Barata (2006), a melhoria do processo de ensino e aprendizagem necessitaria ser o objetivo central da avaliação, a qual deveria ocorrer durante o processo de ensino, e não como o julgamento final do mesmo. A autora (op. cit., p.42) assegura ainda que

[...] a avaliação tem duas finalidades distintas: a primeira diz respeito à apreciação da aprendizagem através de tarefas e/ou atividades avaliativas, e a segunda propicia uma reavaliação dos objetivos de um currículo ou de um programa de ensino.

Segundo Batista (2013), no tocante ao cenário brasileiro, constata-se uma mudança de paradigmas ocasionada pela quebra da abordagem estruturalista, a qual, teoricamente, amplamente cedeu lugar ao modelo comunicativo e suas várias vertentes, a partir da década de 70 . Diante deste contexto, requer-se que os professores transformem os conceitos de linguagem, de forma a não mais exaltar a gramática, como era o costume, e sim, viabilizar a comunicação através dos seus quatro pilares, a citar, produção oral, escrita, auditiva e compreensão de significados.

Scaramucci (2006) afirma que, a partir desta nova perspectiva, a avaliação precisa ser entendida dentro de um contexto específico, sem separar a teoria da prática, e sem ser encarada apenas como o trivial descrever de normas e prescrições da língua. A avaliação deve ser concebida como o ponto de partida do ensino, mediante objetivos bem estruturados que precisam ser alcançados ao longo do processo de aprendizagem.

Segundo Libâneo (1994), as três funções básicas da avaliação seriam: a) didático-pedagógico, que diz respeito ao cumprimento das propostas estabelecidas pelo currículo pedagógico; b) diagnóstica, a qual possibilita a 
elucidação das dificuldades e progressos dos alunos, bem como as do professor e c) de controle, a qual observa diretamente os meios e a frequência das avaliações, além dos resultados dos alunos. Barata (2006) destaca ainda a função de proficiência, a qual observa a capacidade dos alunos de se comunicar em contextos específicos de linguagem.

Entretanto, o que ainda é fortemente observado, como exposto por Batista (2013, p. 100), ao citar Scaramucci (2006, p.51), é que

[...] a avaliação no contexto escolar tem sido praticada como um "conjunto de técnicas complicadas, na maior parte das vezes dissociadas das questões de ensino, planejamento, metodologias e materiais didáticos", servindo como mero apêndice, independente das etapas do ensino de línguas.

Segundo Scaramucci (1997, p. 76) é dada grande importância à avaliação no âmbito discursivo dos professores, mas quando observamos a realidade das ações no ambiente escolar, o que se percebe é uma avaliação carregada de paradigmas, pressupostos e conceitos prescritivos, advindos das experiências pessoais dos professores, tanto como docentes como quando ainda discentes.

Com base nas leituras desenvolvidas durante esta pesquisa, bem como nas observações de colegas professores e até mesmo da minha própria experiência docente, o que percebo corrobora os trabalhos de Rolim (1998) e Scaramucci (1997), segundo as quais ainda hoje há uma tendência de se centrar a avaliação no professor de forma unilateral e muitas vezes arbitrária, estabelecendo-se 0 ato de avaliar através de resultados quantitativos mensurados com notas, não se levando em consideração o papel fundamental do aluno neste processo, nem a necessidade de se aguçar a consciência tanto de docentes como de discentes para a complexidade e importância dos processos avaliativos no ensino-aprendizagem de uma LE.

O que se percebe, portanto, é que apesar de se considerar teoricamente cursos e modelos qualitativos, o que se observa na prática é um regresso ao tradicionalismo quantitativo e classificatório. Scaramucci (2006, p.2) salienta ainda que, mesmo nos cursos de formação de professores de LE, "a avaliação ainda é tratada de forma marginal e periférica, restrita à função classificatória e 
promocional". Os estudos de Suassuna e Bezerra (2010) corroboram este pensamento, uma vez que as autoras afirmam que, historicamente, o que se observa no campo da avaliação é a predominância de uma perspectiva quantitativa, que contrapõe dicotomicamente o certo e o errado, não se construindo significados a partir das práticas realizadas pelos alunos.

A esse respeito, Luckesi (2005, p.17-18) afirma que

\begin{abstract}
A avaliação da aprendizagem ganhou um espaço tão amplo nos processos de ensino que a nossa prática educativa escolar passou a ser direcionada por uma "pedagogia do exame" [...] em que todas as atividades docentes e discentes estão voltadas para um treinamento de "resolver provas" [...] o que importa é a nota: não importa como elas foram obtidas nem por quais caminhos. São operadas e manipuladas como se nada tivessem a ver com o percurso ativo do processo de aprendizagem.
\end{abstract}

Este modelo de avaliação, amplamente difundido e utilizado no cenário educacional brasileiro atual, é conhecido como avaliação somativa. Ao dissertar sobre a mesma, Esteban (2003 apud PAIVA, 2007, p. 89) afirma que

[...] é sobre o produto, no entanto, que se realiza a verificação da aprendizagem: mede-se o desemprenho do estudante a partir dos conhecimentos predeterminados como relevantes pelo professor ou professora, utilizando instrumentos que permitam a comparação do resultado com o proposto. Entende-se que a avaliação do sujeito é o resultado da soma da análise do processo com a verificação do desempenho, gerando uma informação que permite a classificação de cada um.

$\mathrm{Na}$ avaliação somativa, "a aprendizagem é equivocadamente entendida como memorização de um conjunto de conteúdos articulados, obtida através da repetição de exercícios sistemáticos de fixação e cópia" (PAIVA, 2007, p. 89). Para Hoffmann (1999) este tipo de avaliação sobrepõe a mera reprodução dos conteúdos ensinados à real constatação do desenvolvimento de competências e habilidades.

Os estudos de Rolim (1998) ilustram com clareza essa situação. A autora apresenta como um dos resultados de sua pesquisa o fato de que a avaliação, dentre as participantes daquele estudo, ainda é tomada pelo seu 
caráter classificatório, enfatizando-se o que o aluno aprendeu através de provas e testes, os quais são mensurados em notas somadas às observações veladas feitas pelos docentes. A retenção ou promoção do aluno na série em questão é, segundo a autora, o foco principal do ensino.

Trabalhos como os de Porto (2003), Santos (2001) e Belam (2004) revelam que as preferências que professores possuem em momentos pontuais de avaliação estão diretamente relacionados a questões de vocabulário ou de cunho gramatical, o que enfatiza o caráter classificatório e quantitativo da avaliação, cujo foco e objetivo são o produto. Além disso, as autoras sugerem a falta de preocupação, por parte da maioria dos professores que participaram de suas pesquisas, em relação aos problemas diagnosticados nas provas e testes realizados pelos alunos.

Scaramucci (1997, p.77) observa ainda que, independente das suas nacionalidades, os professores possuem uma cultura de avaliar similar, pois colocam suas "práticas a serviço de um ensino autoritário e centralizador, em que a avaliação é verificação de acertos e erros baseada no produto ou no desempenho do aluno".

No tocante ao pensamento observado acima, Zocaratto (2010) assevera que há uma percepção deformada sobre o real papel diagnóstico da avaliação, o qual precisa ser concebido em sua plenitude complexa e constante, e não através de atividades periódicas ou do "julgamento final do aluno". Pode-se dizer que grande parte dos profissionais da educação não entendem as reais funções da avaliação. Em artigo a respeito da competência para avaliar, algumas das conclusões alcançadas por Rolim (1998, p. 254) foram que

[...] de um modo geral, os participantes da pesquisa não possuem um conceito claro sobre o que significa avaliação, restringem 0 ato de avaliar a sua função classificatória, para fins promocionais, dissociam a avaliação do ensino, tratam-na como apêndice e deixam de considerar a influência que ela exerce sobre o ensino, ao avaliar, focalizam mais o produto do que o processo. A avaliação é ainda vista como um símbolo para a manutenção do poder do professor, um instrumento de punição.

A alternativa a este tipo de avaliação seria a avaliação de processo, a qual é formativa, contínua, dinâmica, que considera os aspectos afetivos dos 
indivíduos e "extrapola o uso de testes e provas" (SCARAMMUCCI, 1999, p. 118). Paiva (2007, p. 58) afirma que

[...] como mediador do processo avaliativo, o professor deve estar consciente de que a avaliação não se dá num dia estabelecido e com uma determinada nota. É nos trabalhos individuais, na interação com o grupo e com o mestre, nas relações interpessoais que o professor está apto para analisar o rendimento de cada estudante.

Dessa forma, a avaliação formativa, segundo Avila (2013), acontece durante todo o decorrer do processo de ensino-aprendizagem e visa verificar se os alunos estão atingindo os objetivos previstos. A continuidade e dinamicidade deste tipo de avaliação constituem-se nos pilares para 0 entendimento da complexidade da mesma, a qual pressupõe, além dos instrumentos formais, como exames e provas escritas, a utilização de uma multiplicidade de mecanismos, "tais como a observação sistemática, opiniões e julgamentos dos alunos (auto avaliação)" (ROLIM, 1998, p. 147).

Luckesi (2001, p.76) assegura que a avaliação formativa possui como seu objetivo a melhoria do processo de ensino-aprendizagem, pensamento que vai ao encontro das ideias de Zocaratto (2010), uma vez que a autora afirma que "agregar qualidade à educação" é exatamente uma das principais funções da avaliação da aprendizagem dentro de uma perspectiva formativa (ZOCARATTO, op. cit., p. 33).

Demo (2003, p.42) revela que este tipo de avaliação

[...] começa no primeiro dia do semestre e qualifica-se como processo de acompanhamento permanente do desempenho do aluno, implicando no professor cuidado extremo pelo direito de "aprender bem", e no aluno a confiança de estar progredindo todo dia, ou, se não tiver desempenho adequado, de encontrar o suporte a que tem direito para se recuperar. Implica este processo também 0 acompanhamento individual, tipicamente qualitativo, que descreve a trajetória histórica de cada aluno no sentido de sua evolução constante e progressiva.

Apenas quando imersos neste entendimento é possível compreender 0 intento de Luckesi (2005, p. 44-45) ao afirmar que 
a avaliação deverá verificar a aprendizagem não a partir dos mínimos possíveis, mas sim a partir dos mínimos necessários [...] o médio não pode ser um médio de notas, mas um mínimo necessário de aprendizagem em todas as condutas que são indispensáveis para se viver e se exercer a cidadania [...]

Diante das considerações expostas, e de todas as reflexões ocorridas no percurso da elaboração deste estudo, passei a entender a avaliação, nas palavras de Scaramucci (1997, p. 78), como possuidora de uma

[...] função mais ampla de coletar informações de forma sistemática, para tomar decisões; informações sobre a prática para a prática, e, portanto, um processo dinâmico de tomada de consciência para mudar quando necessário, para reconsiderar, para redimensionar a ação e sua direção.

Assumo nesta pesquisa, também, a postura discursiva dos PCNs (1998, p. 79), segundo os quais

A avaliação é parte integrante e intrínseca ao processo educacional, indo muito além da visão tradicional, que focaliza o controle externo do aluno por meio de notas e conceitos, [...] é um meio de se compreender o que se alcança e por quê. Torna-se, deste modo, uma atividade iluminadora e alimentadora do processo de ensinoaprendizagem, uma vez que dá retorno ao professor sobre como melhorar o ensino, possibilitando correções no percurso e retorno ao aluno sobre seu próprio desenvolvimento.

Entretanto, concordo com Paiva (2007) quando a mesma afirma que a reinvindicação não é da extinção dos métodos ou técnicas tradicionais de avaliação. Na verdade, a forma unilateral e punitiva que os mesmos vêm sendo utilizados é o real problema. A partir do momento que métodos formais e tradicionais de avaliação forem, juntamente com outras atividades avaliativas, inseridos num contexto refletivo e elucidado, no qual alunos e professores tomem em conjunto a responsabilidade pelo processo de ensinoaprendizagem, eles não só serão transformados em instrumentos avaliativos 
coerentes com o discurso vigente dos professores, mas também se constituirão em processos de empoderamento dos envolvidos neste processo.

A não necessidade da abolição de processos quantitativos na avaliação, pode ser explicada pelo fato de que questões qualitativas e quantitativas se complementam. Romão (2003, p.48) afirma que

Não é demais reiterar que a garantia da natureza qualitativa da avaliação independe da expressão final dos resultados, pois ela se constrói durante o processo. Por outro lado, os aspectos quantitativos nunca serão totalmente descartados, uma vez que a oposição absoluta entre quantidade e qualidade constitui um falso dilema, não só no interior da escola, como na vida em geral.

Para Scaramucci (1997), a combinação de provas e testes com outros mecanismos de avaliação que integrem de forma mais precisa atividades reais do uso da LE constituem a conjuntura prototípica do que se espera de uma avaliação dentro do paradigma comunicativo. Assim, faz-se imperativo explicitar alguns métodos alternativos de avaliação, os quais, segundo Barata (2006), "fazem parte do rol de instrumentos de cunho qualitativo". Estes modelos são capazes de auxiliar o professor a desenvolver, junto aos métodos tradicionais de ensino, uma avaliação justa, coerente, dialógica ${ }^{2}$ e que de fato cumpra as funções às quais a avaliação se propõe. Dentre as alternativas de métodos alternativos de avaliação, destaco:

a) As observações de aula, uma vez que um observar contínuo, genuinamente interessado e perspicaz é capaz de oferecer ao professor uma leitura profunda em relação aos problemas enfrentados pelos seus alunos, bem como os avanços e progressos dos mesmos. Para Mesquita (2008, p. 57), “a observação é uma das técnicas que o professor dispõe para avaliar o ensino e o progresso na aprendizagem de seus alunos, para complementar os resultados obtidos através das provas".

\footnotetext{
2 O termo dialógico é adotado nesta pesquisa segundo a concepção de Paulo Freire. Para o autor, as ações dialógicas pressupõem a conscientização crítica da realidade. Dessa forma, o diálogo é o elemento central de uma educação horizontal, na qual professores e alunos se responsabilizam pelo processo de aprender e ensinar (FREIRE, 1987;1996).
} 
Barata (2006) argumenta ainda que as observações de aula precisam ser planejadas e anotadas de forma sistemática, visando observar tanto o progresso quanto as dificuldades enfrentadas pelos alunos, através de recursos como listas e escalas analíticas.

b) A utilização do portfólio, o qual segundo Mesquita (2008, p. 59-60)

[é] uma coletânea de trabalhos realizados pelos alunos que mostram a eles mesmos o seu esforço, desenvolvimento e processo, tornandose assim uma ferramenta valiosíssima para a auto-avaliação do aluno [...] Portfólios também fazem com que os alunos tenham uma maior responsabilidade pela sua avaliação, uma maior interação com professores, pais e colegas, e mais interesse pelo aprendizado, desenvolvendo assim a habilidade de pensar criticamente sobre os trabalhos realizados. (palavra entre colchete minha)

Lopes e Silva (2012, p.9) reiteram que o portfólio documenta o processo de aprendizagem dos alunos ao longo de um tempo determinado e, consequentemente, reflete a melhoria do aluno, tanto para ele mesmo quanto para o professor. Barata (2006, p. 39) corrobora este pensamento, explicando que os portfólios podem inclusive ajudar a "tornar os alunos reflexivos, responsáveis e envolvidos tanto no processo avaliativo quanto no de aprendizagem".

c) A autoavaliação por parte dos alunos. Os estudos de Rolim (1998) apontam para o fato de os professores acreditam que seus alunos não são amadurecidos para se autoavaliarem. A autora entende que a autoavaliação precisa ser um processo consciente, entretanto assume que, a partir do momento que os alunos forem bem conscientes dos objetivos do seu aprendizado e se sentirem responsáveis pelo processo, haverá então a abertura para a autoavaliação. Mesquita (2008, p. 60) afirma que

A auto-avaliação é o processo no qual o próprio aluno avalia o seu desempenho, seja ele um trabalho escolar, uma conduta ou qualquer ação por ele praticada, este instrumento tem como finalidade um melhor conhecimento de si mesmo, incentivando o aluno a melhorar cada vez mais seu desempenho, identificando o que ele aprendeu e o que ainda precisa ser melhorado no processo de ensino e 
aprendizagem. A auto-avaliação é também de suma importância para que os professores conheçam melhor os seus alunos e para que isso aconteça, ela deve estar inserida no projeto pedagógico da escola.

Barata (2006, p.39) informa ainda que o processo de autoavaliação, quando implementado através de critérios claros e objetivos, exercita a responsabilidade dos alunos para com o processo. Entretanto, uma vez mal explorada, "não contribui para a avaliação e passa a ser apenas uma auto-atribuição de notas".

Destaco ainda a necessidade de uma avaliação que leva em consideração o progresso do aluno ao longo do curso, e não que o quantifica em momentos específicos do mesmo. A avaliação formativa não se constitui em uma série de atividades diversificadas e promocionais realizadas no decorrer do curso e depois somadas em uma média aritmética, mas sim no real interesse do professor no crescimento do seu aluno, o qual se dá através da observação continuada e dialógica de todos os desdobramentos ocorridos no desenrolar do processo de ensino e aprendizagem.

Portanto, no intuito de tentar mudar o contexto educacional de ensino de LE no Brasil, o qual Rolim (1998, p. 158) caracterizou como "um ensino centralizador e autoritário, em que a avaliação é entendida como um instrumento disciplinador e promocional", é preciso, nas palavras de Luckesi (1998, p. 28)

[...] situá-la [a educação] num outro contexto pedagógico, ou seja, temos de, opostamente, colocar a avaliação escolar a serviço de uma pedagogia que entenda e esteja preocupada com a educação como mecanismo de transformação social. (palavras entre colchetes minhas)

Desta forma, o autor propõe o resgate, principalmente, da função diagnóstica da aprendizagem, "como um encaminhamento para a ultrapassagem do autoritarismo" (LUCKESI, 1998, p. 44).

Assim, visando resgatar o aspecto diagnóstico da avaliação, a utilização de feedbacks orais e escritos se constitui em uma premissa para a eficácia da 
avaliação. Lopes e Silva (2012, p.17) afirmam que a medida que os alunos conseguem utilizar os feedbacks dos professores tanto para se autoavaliarem quanto para definirem seus objetivos, eles "aumentam as possibilidades de apropriação do seu próprio sucesso". Segundo Barata (2006), as conversas com os alunos podem se constituir em um instrumento de feedback, servindo tanto para esclarecer como para rever os conteúdos trabalhados nos portfólio, bem como para outras finalidades. Para a autora (2006, p. 39),

a conversa é a forma mais eficaz de fornecer feedback aos alunos e prover informações sobre como os processos de aprendizagem e de avaliação estão se efetuando, além de dar direções para que o aluno se torne um aprendiz com sucesso na língua em estudo.

Por fim, reitero a necessidade de se acompanhar o processo de aprendizagem também através da correção diferenciada das atividades avaliativas propostas, oferecendo, através das correções e de feedbacks (orais ou escritos), a possibilidade do aluno observar as suas maiores dificuldades e desenvolver as suas habilidades ao longo do curso, podendo demonstrar seus avanços e perceber os reflexos do mesmo, inclusive, em suas notas (CONCEIÇÃO, 2004). Apresento, no capítulo analítico, o modelo desenvolvido para esta pesquisa que permite utilizar as correções das atividades como elementos propulsores da aprendizagem.

Destarte, diante de todas as considerações feitas, acredito que a avaliação não se restringe à quantificação de atividades esporádicas, mas abraça todo o processo de ensino-aprendizagem de uma LE, alçando olhares para muito além da nota. Através da avaliação, e tão somente quando a mesma é tomada por seus verdadeiros princípios e bases, professores e alunos são capazes de desenvolver uma relação de confiança mútua, na qual ambos se encontram conscientemente responsáveis por todo a dinâmica do processo de ensinar e aprender uma língua. Avaliar é, portanto, permitir que alunos e professores se auxiliem na busca de um objetivo em comum.

Assim, após haver ponderado a respeito das perspectivas sobre avaliação encontradas em vigência no cenário brasileiro, bem como 
alternativas viáveis e mais abrangentes para a mesma, e tendo circundado as principais ideias da literatura na área sobre os conceitos e as funções da avaliação e salientado aqueles que embasam esta pesquisa, discorro a seguir a respeito das crenças de professores em uma instância geral e, posteriormente, aquelas que concernem especificamente aos processos avaliativos.

\subsection{O CONSTRUTO CRENÇAS NO ÂMBITO DA LA}

A grande quantidade de estudos concernentes às crenças de LE com os quais contamos atualmente foi fruto de uma mudança de paradigmas ocorrida na LA a partir da década de 80 , sendo sentida mais efetivamente no Brasil a partir dos anos 90 (BARCELOS, 2001). A autora enfatiza ainda que esta nova perspectiva, possibilitou que as pesquisas mais atuais considerassem as dimensões cognitivas e afetivas de alunos e professores em suas investigações, buscando interpretar não apenas os fatos observados, mas também o contexto em questão, acolhendo a voz dos envolvidos no processo como legítimas e dialógicas.

Corroborando os estudos de Pajares (1992), e de Silva (2005), Bomfim e Conceição (2009) explicam ainda que o interesse no construto crenças vem se desenvolvendo em diversas áreas do conhecimento humano, alçando olhares para muito além da LA, perpassando campos como a Filosofia da Ciência e a Psicologia Social. No que toca à educação, as autoras esclarecem que o estudo sobre crenças é basilar para, dentre outras questões, pensar-se no processo de formação de professores de línguas.

Diante das considerações feitas e destacando-se a complexidade envolta no estudo sobre crenças, não é de se estranhar a proliferação de definições para o termo, como apontado por Pajares (1992), que entende que a profusão de significados pode se originar pela utilização do termo em áreas diversas do conhecimento, constituindo significados distintos em cada uma delas.

É interessante notar, entretanto, que a abundância de nomenclatura não incide negativamente nas pesquisas sobre crenças, mas enfatizam a 
"importância dessa variável nos estudos de Linguística Aplicada" (SILVA; ROCHA; SANDEI, 2005, p. 23). Sobre essa questão, Barcelos (2004) assevera que a dificuldade encontrada até mesmo para se chegar ao consenso sobre uma definição para o termo crenças não só problematiza a investigação desta área como também demonstra a importância do conceito.

llustrando a gama de nomenclatura para o conceito de crenças, Pajares (1992) explica que crenças são “teorias pessoais”. Já Gardner (1998) nomeia o construto como "representações", enquanto Almeida Filho (1993) define o termo como "cultura de aprender". Em 2002, Mastrella define que "Crenças são interpretações da realidade socialmente definidas que servem de base para uma ação subsequente" (MASTRELLA, 2002 p.33). Barcelos (2004, p.132), por seu turno, explica que "as crenças não são somente um conceito cognitivo, mas também social, porque nascem de nossas experiências e problemas, de nossa interação com o contexto e da nossa capacidade de refletir e pensar sobre o que nos cerca". Convergindo com o pensamento de Barcelos (2004, P. 132), Bomfim e Conceição (2009, p.58), expressam que "a experiência é um fator fundamental na formação das crenças".

Em 2006 (p.18), Barcelos afirmou ainda que

[Crenças são] uma forma de pensamento, construções da realidade, maneiras de ver e perceber o mundo e seus fenômenos, coconstruídas em nossas experiências resultantes de um processo interativo de interpretação e (re)significação. Como tal, crenças são sociais (mas também individuais), dinâmicas, contextuais e paradoxais. (palavras entre colchetes minhas)

Quando pensamos especificamente no contexto educacional, as crenças exprimem o que os envolvidos no processo de ensino e aprendizagem "pensam sobre vários aspectos da aquisição de segunda língua" (KALAJA, 1995, p.192). No que tange às crenças sobre o ensino e aprendizagem de LE, e diante do fato de não haver uma definição única para o construto, filio-me ao estabelecido por Silva (2005, p. 77), segundo o qual

[Crenças são] ideias ou conjunto de ideias para as quais apresentamos graus distintos de adesão (conjecturas, ideias 
relativamente estáveis, convicção e fé). As crenças na teoria de ensino e aprendizagem de línguas são essas ideias que tanto alunos, professores e terceiros têm a respeito dos processos de ensino/aprendizagem de línguas e que se (re)constroem neles mediante as suas próprias experiências de vida e que se mantêm por um certo período de tempo. (palavras entre colchetes minhas)

O caráter dinâmico das crenças, exposto por Barcelos (2000), é também retratado por teóricos como Kalaja (1995), que admite que as crenças além de dinâmicas e socialmente construídas, alocam-se em um contexto maior. Já Alanen (2003) reconhece que a dinamicidade das crenças encontra-se no fato da constante mudança observada nas mesmas, uma vez que um aprendiz pode reconstruir uma crença no momento em que estiver discorrendo ou refletindo sobre ela. A partir deste entendimento, considero que entender que as crenças não são estáticas e que são moldadas e moldam a visão geral de ensino dos alunos e dos professores é o que promove o avanço das discussões a respeito do real papel que as mesmas desempenham no contexto de ensino-aprendizagem.

Com base no exposto, compreendo as crenças como o conjunto de princípios articulados consciente ou inconscientemente a partir de variáveis internas e externas ao sujeito, os quais regem o pensamento e, muitas vezes, também a forma como os indivíduos agem em sociedade. São, portanto, exatamente as convicções nas quais professores e alunos encontram respaldo, muitas vezes mecânico e exânime, para o seu proceder dentro e fora de sala de aula.

Na seção seguinte, discorro a respeito dos conceitos relacionados às crenças de professores, as quais constituem um dos pilares centrais deste estudo.

\subsubsection{Crenças de Professores}

À luz das considerações tecidas nas seções anteriores, o estudo de quais são as crenças dos professores, como elas se formam e suas ramificações no contexto escolar tornam-se axiais para a viabilização de 
mudanças no cenário educacional. Este entendimento vai ao encontra dos trabalhos de diversos autores (FREEMAN; RICHARDS, 1996; LUNENBURG; SCHMIDT, 1989; SCHMIDT; JACOBSON, 1990), segundo os quais as atitudes dos professores em sala de aula são decorrência, também, das crenças dos mesmos. A este respeito, Jonhson (1994, p.439) afirma que

[...] as crenças influenciam a percepção e o julgamento que, alternadamente, afetam o que o professor diz e faz na sala de aula. Em segundo lugar, as crenças desempenham um papel crítico na maneira como eles aprendem a ensinar, isto é, como eles interpretam novas informações sobre aprendizagem e de ensino e como essas informações são traduzidas na prática da sala de aula e finalmente, a compreensão das crenças de professores se torna essencial para melhorar a prática de ensino e os cursos de formação de professores.

Para Araújo (2006), as crenças são uma das grandes forças atuantes no contexto da sala de aula e as ações dos professores podem ser um reflexo de suas crenças a respeito dos processos de ensino-aprendizagem, principalmente no caso dos professores que não tiveram a oportunidade de refletir sobre as suas práticas (BARCELOS, 2004). Bandeira (2003, p. 65), expõe que as crenças "são consideradas princípios filosóficos que orientam a prática do professor".

Indo ao encontro deste pensamento, Almeida Filho (1993) estabelece que as crenças dos professores podem guiá-los através das diversas dimensões do ensino, tais como o preparo da aula, a dinâmica das interações na sala e a avaliação dos alunos. Assim, as crenças dos docentes possivelmente são responsáveis por diversas práticas e hábitos perpetuados na conjuntura escolar (JOHNSON, 1992), uma vez que, segundo Pajares (1992), a repetição da forma pela qual foram expostos à LE é uma tendência dos professores.

Para Conceição (2004), as crenças dos docentes estão interligadas às suas experiências e ações, e, à esse respeito, Miccoli (2010) afirma que as ações podem ocasionar experiências que, por sua vez, venham a gerar novas crenças. No que concerne às experiências anteriores de aprendizagem, Vieira Abrahão (2004) discute ainda o fato de poucos professores terem tido a oportunidade de refletir sobre as mesmas ou sobre as crenças por elas 
originadas, o que corrobora os estudos de Bandeira (2003), segundo o qual outra característica das crenças é o fato de termos ou não consciência sobre elas. Bandeira (op. cit., p.65) afirma que as crenças são "uma disposição para a ação; e podem transformar-se em regras de comportamento, devido ao alto grau de probabilidade e estabilidade".

Entretanto, segundo Mukai e Conceição (2012), nem sempre é possível estabelecer uma relação direta entre crenças e ações, haja vista que além das crenças, os sujeitos também se valem de suas reflexões e experiências e, portanto, nem sempre agem conforme as suas crenças. Sobre o assunto, Borg (2003) e Barcelos (2006) asseveram que as ações e práticas dos professores são também delineadas pelo contexto psicológico, social e ambiental que os cercam. Tais fatores podem convergir para a inconsistência entre as crenças e práticas dos professores no ambiente escolar, principalmente quando as práticas não foram submetidas à reflexão.

Percebe-se, então, a necessidade de ocasionar um momento de reflexão, para que o professor possa enxergar o processo sob uma outra perspectiva, permitindo-se avaliar a sua própria visão de ensino-aprendizagem. Dutra e Mello (2004) afirmam que sem atividades de cunho reflexivo, a prática do professor corre o risco de se tornar estagnada e ser baseada na simples reprodução, a qual não leva em conta o contexto das ações pedagógicas.

Esse pensamento corrobora a afirmação de Arruda (2008), pois, segundo a autora, "para que haja mudança nas experiências de ensino e aprendizagem em sala de aula, é importante que, primeiramente, o professor se engaje em um processo reflexivo para poder entender melhor sua prática pedagógica" (ARRUDA, 2008, p. 29). A autora afirma ainda que "a consciência sobre suas crenças pode permitir a compreensão e a mudança de sua prática pedagógica". (ARRUDA, 2008, p.98).

Com essa finalidade, e visando o desenvolvimento de professores mais críticos e autônomos, capazes de explicar o que ensinam, bem como o porquê de ensinarem da forma que o fazem, os professores devem, de acordo com Almeida Filho (1993), serem expostos a modelos alternativos, diálogo esclarecedor, leituras teóricas relevantes, ensino auto-observado, e, certamente, reflexão intensa e continuada. Todos os pressupostos elencados 
por Almeida Filho (op. cit.) foram cuidadosamente levados em consideração no desdobrar desta pesquisa.

Tendo elencado os aspectos relevantes para este estudo sobre as questões relacionadas às crenças de professores, abordo, a seguir, os assuntos que concernem especificamente às crenças relacionadas à avaliação.

\subsubsection{Crenças de professores sobre Avaliação}

Barata (2006, p. 40) descreve crenças sobre avaliação de aprendizagem de LE como

[...] um conjunto de conceitos, ideias e opiniões sobre avaliação, resultantes ou não de experiências em contexto de ensino, aprendizagem e avaliação. As crenças podem ser transmitidas, construídas e/ou reconstruídas em consonância com a história, a cultura, o meio e o indivíduo. Portanto, as crenças sobre avaliação orientam, especificamente, professores e alunos a respeito do que seja avaliar e ser avaliado dentro do contexto social em que vão atuar como professores e/ou em que estudam.

Corroborando a definição acima, Scaramucci (1997, p. 77) adota o termo "cultura de avaliar", definindo-o como

[...] crenças, pressupostos teóricos, atitudes e mitos - construídos ao longo dos anos a partir de nossas experiências de aprender e ensinar, muitas vezes superadas e sem reflexão e que acabam por determinar, na maioria das vezes de forma inconsciente, os rumos de nossa prática

Indo ao encontro das definições cunhadas por Barata (2006) e Scaramucci (1997), Rolim (2004) afirma que crenças sobre o que é avaliar podem vir a legitimar as práticas avaliativas do professor uma vez que haja um déficit na sua formação acadêmica. Assim, a necessidade de uma preocupação mais intensa com os cursos de formação de professores fica evidente, 
entendendo-os como os pilares da instrução de professores reflexivos e capazes de gerar uma mudança que vai além do discurso.

$\mathrm{Na}$ hipótese do professor não refletir sobre a importância, a complexidade e as funções da avaliação no processo de ensino-aprendizagem de LE, ele tende a enxergar as suas próprias experiências como o caminho certo e, muitas vezes, único a ser trilhado, ainda que este seja constantemente frustrante para todos os envolvidos no processo. Vindo ao encontro deste pensamento, estão alguns trabalhos de LA sobre os quais discorro a seguir.

Em sua dissertação de doutorado, Barata (2006) discorreu a respeito das crenças sobre avaliação de quatro professoras em formação, a partir das metáforas presentes no discurso das docentes. Através da condução de um estudo de caso, Barata pode observar que todas as participantes compartilhavam de experiências de avaliação tradicionais, cujos instrumentos se resumiam em testes escritos e orais. Consequentemente, esta era a referência de avaliação que as participantes dispunham, fazendo com que elas, por exemplo, apontassem - em um dos questionários realizados - a avaliação como o último item a ser trabalhado no curso.

Quando analisando as metáforas levantadas pelas participantes no tocante à avaliação, algumas das palavras encontradas foram "ameaça", "tensão", "sufocação", "trauma", "punição", "limitação" e "medida". Essas palavras se refletiram nas crenças levantadas pelas professoras, as quais, segundo Barata, decorreram do modelo de avaliação experienciado por elas.

As crenças no que concerne à avaliação levantadas foram:

- Avaliação é prova;

- Avaliação como equivalente a nota;

- A avaliação é a verificação de erros e acertos;

- A avaliação mede e revela o que o aluno aprendeu;

- A avaliação não aponta para as dificuldades;

- A avaliação gera nervosismo e insegurança;

- A avaliação pune o aluno.

Através da análise das experiências anteriores das participantes com avaliação, a autora pode observar ainda como as mesmas se refletiram em 
várias das crenças apresentadas, além de se traduzirem em ações nas salas de aulas das mesmas.

Além disso, Barata elencou ainda as crenças provenientes do modelo de avaliação idealizado pelas participantes, a citar:

- Avaliação como momento inerente ao processo de aprendizagem;

- Avaliação como diagnóstico da aprendizagem; ajuda o processo de aprendizagem; como reelaboração do trabalho do professor;

- Avaliação controla a eficiência do ensino; avaliação como prova ou atestado da aprendizagem do aluno;

- Avaliação interage com o processo de aprendizagem;

- Avaliação como apreciação da aprendizagem.

Na conclusão de seu trabalho, Barata observa a discrepância entre o que as professoras idealizam como avaliação e as crenças que elas apresentam através de suas metáforas e práticas pedagógicas. Por fim, a autora discursa sobre a forte relação das crenças advindas das experiências das participantes e suas tomadas de atitudes em sala de aula, bem como da necessidade de se abrir mais espaços para a reflexão sobre o tema avaliação.

Em artigo publicado na revista Horizontes de Linguística Aplicada sobre as crenças de professores recém-formados sobre a avaliação em língua inglesa, Batista (2013) reforça os achados de Barata (2006), ao observar que as participantes da sua pesquisa possuíam suas práticas moldadas por crenças sobre avaliação cujas origens remontavam suas experiências anteriores de aprendizagem. Através de um curso reflexivo de oitenta horas divididas em quatro módulos, Batista desenvolveu questionários, diários reflexivos e sessões reflexivas com quatro professoras recém-formadas. Apesar de não levantar crenças específicas, o autor observou, por meio da análise dos questionários e das sessões reflexivas, que algumas das participantes possuíam crenças sobre avaliação pautadas no produto, visando obter "a média estipulada pela escola" (BATISTA, 2013, p.104), enquanto outras apresentavam uma visão superficial sobre as funções da avaliação. Ele finaliza o artigo explicando que o curso oportunizou momentos de reflexão 
sobre as crenças das participantes, conscientizando as mesmas das funções primordiais da avaliação.

Outra pesquisa que se preocupou em entender as crenças dos professores no que tange à avaliação se trata da dissertação de mestrado de Jucimara Paiva (2007), a qual desenvolveu um estudo de caso sobre as crenças de uma professora de inglês sobre a avaliação contínua nos ciclos de desenvolvimento humano. As crenças da participante da pesquisa no tocante à avaliação foram elencadas da seguinte forma:

- Crenças de que avaliar é aplicar prova escrita;

- Crenças de que só a nota avalia;

- Crença no uso da avaliação como instrumento punitivo;

- Crenças de que a avaliação tradicional é a natural.

A semelhança ímpar das crenças apontadas nesta pesquisa com aquelas elencadas por Barata (2006) pode ser observada até mesmo na escolha das palavras utilizadas para denominar as crenças. Além disso, ao discorrer sobre as falas da professora participante que corroboram a elucidação das crenças expostas, a autora também enfatiza a relação das experiências anteriores da participante com as crenças e tomadas de atitudes em sala de aula.

Apresentando uma visão um pouco diferenciada, a dissertação de mestrado de Flain-Ferreira (2005) se constituiu em uma pesquisa-ação, a qual visou observar as crenças sobre avaliação de LE de uma professora-aluna de inglês em um contexto de formação inicial em três momentos distintos: Antes, durante e após a intervenção realizada na pesquisa. Utilizando-se de entrevistas, questionários, diários e ciclos de leitura e discussão no curso de extensão oferecido para os propósitos da pesquisa, as seguintes crenças sobre avaliação foram levantadas pela pesquisadora nos momentos diferentes do estudo: 


\section{QUADRO 1 - COMPARATIVO DAS CRENÇAS APRESENTADAS PELA PROFESSORA-ACADÊMICA, A RESPEITO DA AVALIAÇÃO EM LÍNGUA ESTRANGEIRA, NAS TRÊS FASES DO TRABALHO DE PESQUISA-AÇÃO}

Crenças apresentadas antes da Intervenção
Crenças apresentadas no

período da Intervenção
Crenças apresentadas após a

Intervenção
- A avaliação tradicional pode causar medo;

- A avaliação pode ser uma ameaça de perda de prestigio;

- A prova não deve ser o púnico instrumento de avaliação;

- O desempenho em aula deve ser avaliado;

- A habilidade oral é a que melhor avalia o desempenho do aluno;

- Deve haver coerência entre o que é ensinado e o que é avaliado;

- O erro pode ser construtivo aprendizagem.
- A avaliação não deve ser motivo de nervosismo;

- O desempenho em sala de aula deve ser avaliado;

- Os critérios de avaliação devem ser conhecidos dos alunos;

- Deve haver coerência entre o que é ensinado e o que é avaliado;

- A avaliação serve para detectar os erros e corrigilos para ajudar o aprendiz;

- Os gramaticais não devem ser tolerados;

- A participação em aula é fundamental para a aprovação e

- A avaliação instituída é para ser seguida.
- Às vezes o aluno valoriza mais a avaliação que o aprendizado;

- A prova é um instrumento preciso de avaliação;

- É mais produtivo, para o aluno, a avaliação através de trabalho;

- A avaliação serve para controlar a realização das tarefas em sala;

- Os critérios de avaliação devem ser conhecidos dos alunos;

- Deve haver coerência entre o que é ensinado e o que é avaliado;

- O erro deve ser construtivo na aprendizagem;

- A avaliação serve de instrumento para que professor e aluno comprovem o que é ensinado e aprendido;

- O sistema avaliativo é esse (aprovação através da nota) não tem como não pensar em avaliação;

- É importante estudar mais sobre avaliação.

Flain-Ferreira (2005, p. 116)

Após o término da pesquisa e diante das crenças listadas acima, a autora citando Vasconcellos (2002) concluiu que

[...] a acadêmica termina este trabalho de pesquisa-ação com algumas mudanças emergentes em relação aos aspectos práticos da avaliação, mas conceitualmente continua predominantemente presa às suas concepções iniciais, mais próximas do Paradigma Tradicional de avaliar.

Há ainda que se ressaltar o constatado pela pesquisadora de que os dados apontados nas entrevistas e questionários revelam uma forte coerência 
entre as crenças e práticas da participante no que toca à avaliação e suas práticas anteriores de ensino.

Nos quatro estudos mencionados é possível observar a falta de conhecimento dos docentes que participaram das pesquisas sobre os princípios básicos da avaliação, as posturas tradicionalistas inferidas nas crenças e observadas na prática e, principalmente, a profunda relação entre as crenças elencadas e as experiências anteriores de aprendizagem dos participantes, apesar de, em alguns momentos, ser observada também a discrepância entre crenças e ações no processo avaliativo de LE.

Destarte, além da preocupação com os cursos de formação de professores, constata-se a necessidade de outros momentos que propiciem ao professor que já está no exercício de suas funções a oportunidade de parar, ler a teoria a respeito da sua própria prática, ponderar sobre a maneira como avalia e o porquê de avaliar daquela forma e discutir com pessoas que, assim como ele, estão buscando melhorar a qualidade do ensino de LE. E é exatamente a este propósito que se presta este estudo.

Assim, após ter discorrido sobre alguns trabalhos sobre crenças de professores no tocante à avaliação, pondero a seguir sobre como intervir e permitir que o professor reflita a respeito da sua própria performance.

\subsection{REFLEXÃO E ATITUDE: O CAMINHO PARA A RESSIGNIFICAÇÃO}

Apesar do entendimento de que as crenças são difíceis de serem mudadas, uma vez que, segundo Horwitz (1996), elas podem ser criadas também a partir das experiências anteriores de aprendizagem e tendem a estar vigorosamente arraigadas, concordo com o exposto por Arruda (2008, p.34), a qual afirma que as crenças "são dinâmicas e modificáveis, ou seja, podem ser ressignificadas, uma vez que sofrem forte influência do contexto vivido". Esta visão vai ao encontro dos trabalhos de Blatyta (1999), Araújo (2004) e Barcelos (2006). Barcelos (2007) ressalta ainda a importância de estudos sobre mudanças de crenças, pois os mesmos podem ajudar a evidenciar e compreender os fatores que influenciam ou proporcionam as mudanças. 
Simão et al. (2005, p. 175 apud ARRUDA, 2008, p. 29) afirmam que a mudança

é um processo complexo que pressupõe a interação entre fatores pessoais e contextuais [...] é um processo interactivo e multidimensional que inclui mudanças ao nível das crenças e das práticas e a articulação entre ambas [...] está intrinsecamente ligada à aprendizagem e aos desenvolvimento.

O modelo de mudança conceitual de Posner et al. (1982) corrobora a assertiva de Arruda (op. cit.) pois os autores afirmam que é possível, através de uma reflexão e da assimilação de novas informações, mudar conceitos préexistentes, uma vez que, a partir do conflito entre a informação antiga e a nova, e a percepção da veracidade ou da adequação do novo conceito, as crenças anteriores são substituídas ou reorganizadas, o que é chamado por Posner et al. (1982) de "acomodação", e é entendido neste estudo como ressignificação.

Barcelos (2006, p. 26) assegura que "a mudança tem a ver com a existência de momentos catalisadores de reflexão, e de consequente questionamento e/ou transformação de uma crença na prática." Corroborando a ideia da autora, Arruda (2008, p. 29 - 30) explana que

\begin{abstract}
Para que haja uma mudança nas experiências de ensino e aprendizagem em sala de aula, é importante que, primeiramente, o professor se engaje em um processo reflexivo para poder entender melhor sua prática pedagógica [...]. O engajamento em um processo de reflexão pode conscientizar os professores sobre suas experiências, crenças e as inconsistências de suas práticas pedagógicas.
\end{abstract}

Destarte, percebe-se que no âmago do processo de ressignificação de crenças encontra-se a reflexão. Kemmis (1986, p.5 apud AVILA, 2013, p.30) expõe uma definição de reflexão que vem ao encontro das convicções desta pesquisa, pois, para o autor,

Reflexão não é apenas um processo psicológico individual. É uma ação orientada, introjetada historicamente, dotada de contornos sociais e políticos, compromissada em situar as pessoas nos 
contextos sociais que as envolvem, levá-las a serem participes das atividades sociais e a tomarem partido diante de questões importantes. Além disso, o material sobre o qual a reflexão atua nos é dado social e historicamente. Por meio da reflexão e da ação que ela informa, podemos transformar as relações sociais que caracterizam os contextos nos quais estamos inseridos.

Concordo com os autores aludidos, pois acredito que o momento da reflexão é o que propicia ao professor a oportunidade de observar suas próprias práticas através de uma ótica externa, guiado tanto pelo pesquisador, quanto pelo contato com a literatura corrente na área, fato que pode expandir os horizontes do docente e contribuir amplamente para o processo de ressignificação das crenças. Ratificando este pensamento, Woods (2003, p. 202) afirma que, apesar das crenças serem individuais, elas tendem a ser mais facilmente ressignificadas a partir de interações sociais em âmbitos ou contextos específicos. Paiva (2007, p. 45) reforça ainda que

\begin{abstract}
As experiências, por sua vez, podem modificar suas crenças (dos professores), reforçá-las ou não provocar grandes perturbações em suas ações, caso não tenham sido significativas para ele. Entretanto, salientamos que, após um certo contato com crenças variadas, a compreensão do professor sobre determinado assunto pode ser alterada pela reflexão provocada pelo conhecimento teórico e pela interação social.
\end{abstract}

Além da reflexão, Arruda (2008) afirma que é necessário que o professor ateste a validade e a eficiência das novas propostas apontadas, para que estas possam vir, então, a substituir as anteriores. Entretanto, enfatizo que este processo não é linear nem prescritivo, dando-se através de tentativas, acertos, equívocos, frustrações, retornos às crenças antigas e novas investidas nos modelos alternativos, sendo necessário o tempo e a disposição do docente para a consolidação dos mesmos. Apenas a partir da implementação eficaz de práticas alternativas, advindas de uma reflexão prospectiva ${ }^{3}$ à luz de teorias embasadoras, o professor pode se sentir seguro para abandonar as práticas

\footnotetext{
${ }^{3}$ Segundo Arruda (2008), enquanto a reflexão prospectiva é aquela em que são indicadas alternativas e cuidados (justificados) que apontem para novas ações educativas, sejam planejando futuros ou ações semelhantes em novos espaços, a reflexão retrospectiva é aquela que diz respeito aos fatos que aconteceram na ação educativa, apontando as razões da ocorrência e, por vezes, justificando-as.
} 
antigas, haja vista a eficácia das novas. Este processo pode culminar na ressignificação das crenças, seguida pela mudança de ações na prática pedagógica do professor.

Entretanto, a autora ressalta que nem sempre a ressignificação ocorre, e, ainda que ocorra, nem sempre resulta na mudança da prática pedagógica do docente, seja por razões externas ao professor, como o contexto educacional no qual está inserido, ou questões internas, como variáveis emocionais. Este fato corrobora os estudos de Almeira Filho (2005), segundo o qual a exposição a modelos alternativos de avaliação, bem como a crenças diferenciadas e à teoria na área podem não ser suficientes para transformar a conduta dos professores no ambiente escolar, optando os mesmos pela manutenção da sua prática pedagógica ainda que diante de todas as alternativas apresentadas.

Além dos aspectos já mencionados, há de se considerar, também, diversos outros fatores que podem influenciar o processo de ressignificação de crenças, tais como as interações do docente com alunos, recursos e outros professores, bem como os valores pessoais do professor em questão, os quais constituem o contexto sociocultural no qual o mesmo está inserido, e podem interferir de forma parcial ou decisiva na mudança das crenças deste (ARRUDA, 2008).

O modelo de ressignificação de crenças e mudança de ações do professor desenvolvido por Arruda (2008), o qual é ilustrado pela figura abaixo, descreve com precisão a visão de ressignificação de crenças norteadora desta pesquisa. 
FIGURA I

DIAGRAMA ANALÍTICO DOS PROCESSOS DE RESSIGNIFICAÇÃO DE CRENÇAS E MUDANÇA DE AÇÕES DO PROFESSOR

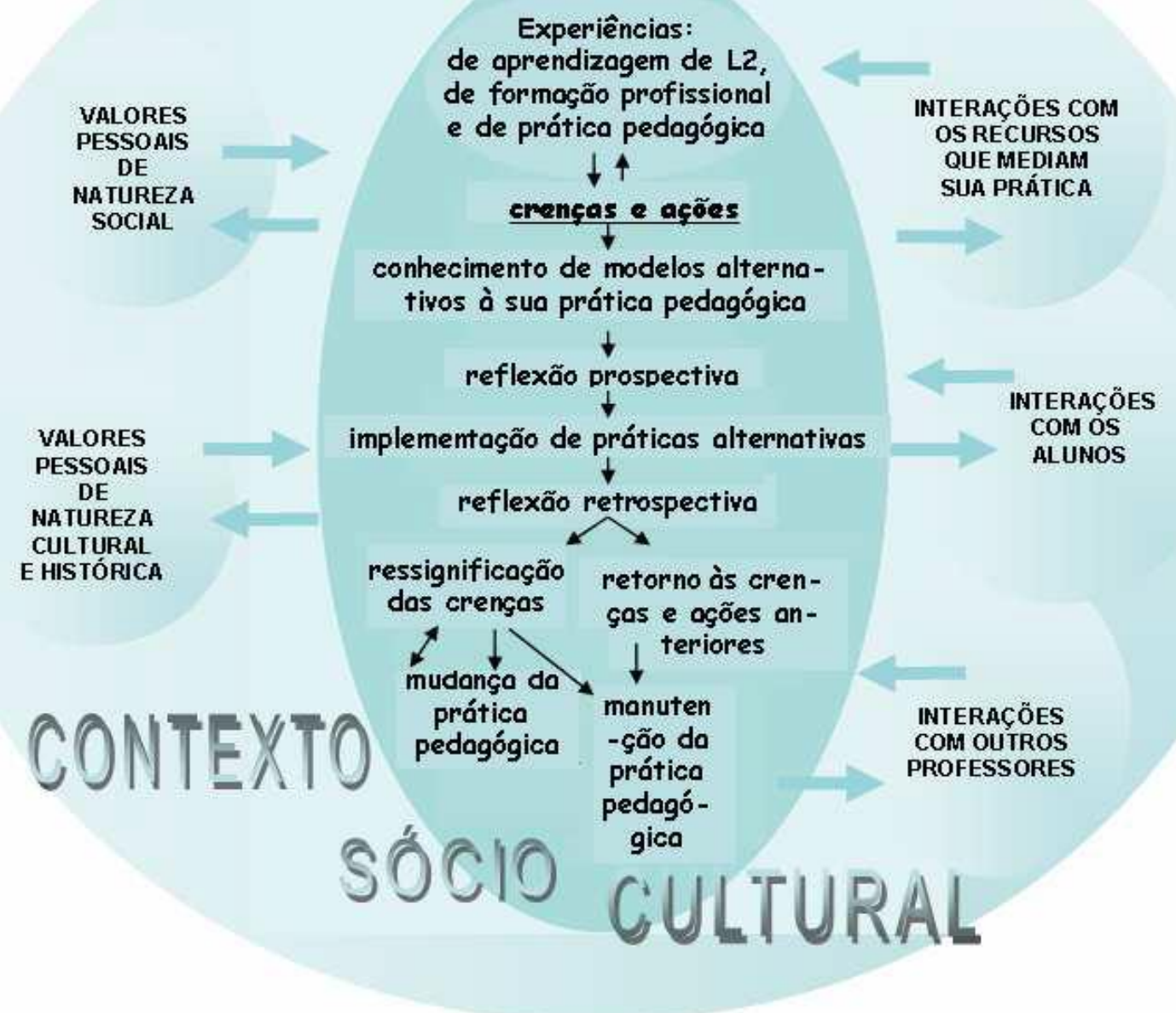

Extraído de Arruda (2008, p.33)

Diante de todas as considerações feitas, é preciso relembrar que, segundo Paiva (2007), o processo de ressignificação é lento e gradual, e somente através do passar do tempo pode vir a ser percebido nas tomadas de decisões do professor. Para esta pesquisa, entendo que o processo de ressignificação de crenças aloca-se em uma conjuntura muito maior, a qual engloba o próprio despertar do professor reflexivo, e não apenas o refletir sobre um determinado aspecto do processo. A este respeito, Avila (2013, p. 32) afirma que 


\begin{abstract}
A formação de um professor reflexivo é um processo complexo e gradativo, que exige, entre outras coisas, um aprofundamento teórico que possibilite a este profissional entender. Isso significa que 0 docente precisa repensar a sua prática e como esta pode melhorar a partir da sua reflexão.
\end{abstract}

Ainda segundo Avila (2013), o professor reflexivo é aquele capaz de repensar continuamente a sua prática, lançando um olhar indagador sobre 0 que faz, para, então, ser capaz de explicitar e explicar suas próprias escolhas, além de mudar de direção quando percebe que há caminhos mais eficientes e promissores a serem seguidos.

Assim, o presente estudo entende a implausibilidade de se tentar averiguar a ressignificação exata das crenças do professor pesquisado, uma vez que, como já explicado, a ressignificação das crenças pode não ser expressa através das ações do professor, além do tempo limitado da pesquisa não permitir o acompanhamento do processo. O estudo pretende, no entanto, observada a necessidade de modelos alternativos de avaliação, e, após a exposição dos mesmos em um processo de reflexão guiado, observar a existência de possíveis indícios de mudança de atitude e pensamento na prática do professor no que concerne o ato de avaliar.

Havendo finalizado a exposição da teoria à luz da qual esta pesquisa é realizada, discorro no capítulo seguinte a respeito da metodologia que embasa a mesma. 


\section{METODOLOGIA}

Conte-me e eu esqueço. Mostre-me e eu apenas me lembro. Envolva-me e eu compreendo.

Confúcio

\subsection{INTRODUÇÃO}

O presente estudo desenvolveu-se à luz das pesquisas qualitativas de base interpretativista e intervencionista, constituindo-se em um estudo de caso qualitativo de cunho interventivo.

Assim, neste capítulo, discorro sobre os princípios metodológicos que norteiam este trabalho, descrevo o contexto da pesquisa, delimito os participantes da mesma, exponho os instrumentos utilizados na coleta de registros e detalho os procedimentos para a análise dos dados. Subsequentemente, concluo a seção ponderando sobre os fundamentos éticos à luz dos quais esta pesquisa é conduzida.

\subsection{A PESQUISA QUALITATIVA}

Laville \& Dionne (1999), ao dissertarem a respeito da pesquisa qualitativa, afirmaram que esta dá voz ao real, considerando os valores, as motivações e as representações, ainda que estes sejam dificilmente mensuráveis. Entende-se, assim, que a replicabilidade dos resultados não é uma preocupação desta modalidade de pesquisa, pois entende-se que cada contexto possui um significado próprio. Por sua vez, Moura Filho (2000, p. 6) expõe que

A vertente qualitativa dá ênfase à natureza da realidade socialmente construída, à intima relação entre o (a) pesquisador(a) e o que é estudado e às restrições circunstanciais que moldam a pesquisa. $O$ enfoque qualitativo é fenomenológico, indutivo, descritivo, holístico e assume uma realidade dinâmica. 
Outra característica pontual da pesquisa qualitativa apontada por Denzin \& Lincoln (2006), diz respeito à natureza transdisciplinar desta modalidade. Os autores afirmam que a pesquisa qualitativa "não privilegia nenhuma única prática metodológica em relação a outra” (op. cit., p. 20).

A partir destas considerações iniciais, percebe-se que a pesquisa qualitativa busca não apenas apreender o contexto, mas também entender os fatores que o constituem e os motivos que o transformam. Por esta razão, esta modalidade de pesquisa faz-se ideal para este estudo, haja vista que a dinâmica apresentada pelas crenças dos professores faz parte das variáveis presentes na sala de aula e são capazes de direcionar os procedimentos exercidos pelos docentes dentro e fora da mesma (PAJARES, 1992).

Segundo Johnson (1992), é crescente a percepção de que as crenças dos professores não apenas influenciam a sua tomada de decisão em sala de aula, mas também as interações que ocorrem nela. Por conseguinte, acredito que a sala de aula se apresenta como o local ideal para que o pesquisador colha registros genuínos sobre crenças de ensino-aprendizagem de professores, haja vista que é o ambiente no qual as interações entre alunos e professores ocorrem naturalmente. Este pensamento corrobora os estudos de Moura Filho (2000), o qual esclarece que as pesquisas desenvolvidas em sala de aula de LE possuem como objetivo a identificação das variáveis pedagógicas envolvidas no processo de ensino e aprendizagem, e que as mesmas podem estar relacionadas a diversos fatores.

Assim, assumo, neste estudo, a postura adotada por Chizzotti (2006, p. 26), segundo o qual "o termo qualitativo implica uma partilha densa com pessoas, fatos e locais que constituem objetos de pesquisa, para extrair desse convívio os significados visíveis e latentes que somente são perceptíveis a uma atenção sensível". Entendo a indispensabilidade da adoção de uma postura êmica, a qual possibilita a interpretação das condutas observadas através do ponto de vista dos membros do grupo. Assim, inseridos no contexto de pesquisa, os pesquisadores podem aprender os costumes do grupo em questão e interpretar o que é observado através da ótica da cultura local (VAN LIER, 1988).

A partir da adoção de uma postura êmica, o pesquisador pode conseguir de fato observar, inferir, refletir e, possivelmente, interferir no contexto escolar 
do ensino de LE em questão. Na posição de pesquisadora, preciso não somente observar o evento, mas adotar uma postura participante para conseguir, diante do fenômeno, "interpretar os significados que as pessoas dão a eles" (CHIZZOTTI. 2006, p.28).

Além disso, a necessidade da criação de um relacionamento de confiança entre pesquisador e participante é outra característica fundamental deste estudo, a qual somente pode ser concretizada pela adoção da vertente qualitativa. Como um dos intuitos é, haja vista a necessidade, criar um ambiente propício para o início da ressignificação de determinadas crenças, a relação entre os envolvidos nesta pesquisa constitui-se fator decisivo para que os objetivos sejam alcançados. Dessa forma, a necessidade da utilização da pesquisa qualitativa novamente é confirmada, pois, nas palavras de Gergen e Gergen (2006, p. 384), ao discorrerem sobre este tipo de pesquisa:

\begin{abstract}
À medida que nossas metodologias se tornam mais sensíveis à relação dos pesquisadores com seus sujeitos (considerando-a dialógica e capaz de levar a uma construção conjunta), à relação dos pesquisadores com suas audiências (considerando-a interdependente) e à negociação do significado dentro de qualquer relação (enxergando nela um potencial para ramificar-se pela sociedade) a atividade individual deixa de ser nossa principal preocupação. Efetivamente criamos a realidade do processo relacional.
\end{abstract}

Segundo os autores, a estimulação do diálogo, o qual pode vir a transformar-se ao longo das complexidades da pesquisa, passa a ser o intuito da pesquisa qualitativa.

Ressalto ainda que, para Andre (2008), a pesquisa qualitativa é o campo metodológico no qual se entende a íntima relação entre fatos e valores, o que, no caso desta pesquisa, pode levar o pesquisador a compreender o porquê das crenças dos professores possuírem papel muitas vezes decisivo em suas tomadas de decisões. Este entendimento não apenas auxiliaria a compreensão do motivo pelo qual os professores agem da forma como agem em sala de aula, mas também ajudaria na percepção da necessidade de mudanças, e possivelmente em como realizá-las. 
Corroborando todos os pensamentos elucidados até o momento, Denzin \& Lincoln (2006) afirmam que um dos pilares que apoiam a pesquisa qualitativa é a interpretação dos registros coletados dentro de um contexto específico, em seus cenários naturais. No tocante à pesquisa interpretativista, Schwandt (2006) afirma que "para encontrar significado em uma ação, ou para afirmar que se entende o que uma determinada ação significa, é necessário que se interprete de um modo específico o que os atores estão fazendo" (op. cit. p. 196). O autor expõe ainda que a ação humana é inerentemente significativa e que o objetivo da epistemologia interpretativista é exatamente reconstruir os significados e autocompreensões desta ação.

Outra característica da pesquisa qualitativa interpretativista levantada por Erickson (1990), é o fato desta não possuir como ponto fulcral a busca pelo previsível. Na verdade, o autor afirma que este tipo de pesquisa objetiva entender as escolhas humanas e os porquês das mesmas, haja vista a gama de conhecimento que essa compreensão pode ocasionar. Concordo com os autores, ao passo que entendo a necessidade de observar como as crenças dos professores influenciam sua prática, a qual só pode ser observada na sala de aula. Além disso, vislumbro a capacidade de transformação do cenário educacional advinda dessa modalidade de pesquisa.

Por fim, de acordo com Freebody (2003), a pesquisa qualitativa se divide em três grandes áreas de investigação: estudo de caso, etnografia e pesquisaação. $O$ autor argumenta que as três são membros da mesma família metodológica e que apresentam diversos pontos em comum. Entretanto, possuem características pontuais que as diferenciam. Assim, o estudo de caso, particularmente o estudo de caso interventivo, se adéqua melhor aos fins específicos deste trabalho, conforme elucido mais profundamente nas seções seguintes.

\subsubsection{O Estudo de Caso}

Merriam (1988) afirma que, no campo da educação, o estudo de caso, especialmente o de cunho qualitativo, é amplamente utilizado como paradigma metodológico, pois o mesmo constitui-se em "uma descrição e análise intensiva e holística de uma única instância, fenômeno ou instituição social" (op. cit, p. 
21. Tradução minha). Em trabalho posterior, Merriam (1998) assegura que a principal característica de um estudo de caso é a delimitação do objeto de estudo, ou seja, o caso em si.

A este respeito, Faltis (1997) relata que o estudo de caso trabalha com um fenômeno inserido em um sistema bem delineado aos olhos do pesquisador, tal como um professor, uma escola ou uma sala de aula. Segundo o autor, esta delimitação permite ao pesquisador não apenas fornecer detalhes sobre o fenômeno e o contexto observados, mas também dialogar a respeito das conclusões e teorias que embasaram o estudo.

Ainda no tocante ao caso, Merriam (1998) afirma que o mesmo pode ser escolhido por constituir-se em um fenômeno intrinsecamente interessante, a ponto de estimular o pesquisador a querer alcançar uma compreensão mais ampla e detalhada sobre o mesmo. Este é exatamente o caso em questão, haja vista que as pesquisas sobre avaliação, conforme explicitado no capítulo teórico, demonstram a carência da área e a necessidade de se entender 0 motivo pelo qual professores avaliam como o fazem.

Freebody (2003, p.80) revela ainda que

o estudo de caso foca numa instância particular da experiência
educacional e tenta ganhar reconhecimento teórico e profissional a
partir de uma completa documentação da mesma. Pesquisadores
utilizam os estudos de caso como uma forma de conduzir e
disseminar pesquisa para impactar a prática e refinar as formas nas
quais a prática é teorizada.

Outra característica levantada por Merriam (1998) e de especial importância para a presente pesquisa, diz respeito ao fato do estudo de caso utilizar-se de todo e qualquer método para a coleta de registro e análise de dados necessário, não se atendo, como nas pesquisas positivistas, às nomenclaturas metodológicas. Assim, de testes a entrevistas, todos os métodos são válidos, apesar do autor salientar que alguns são mais utilizados do que outros. A relevância desta assertiva para esta pesquisa está no fato de que o presente estudo utilizou-se de diversos mecanismos e técnicas para coleta de dados, e, para tanto, encontrou embasamento teórico nos preceitos do estudo de caso para o fazer. 
Tanto Merriam (1998) quanto Faltis (1997) afirmam que o estudo de caso preocupa-se em oferecer uma descrição e explicação holística do fenômeno observado, sendo esta uma das características que o difere de outros paradigmas metodológicos. Além disso, Merriam (op. cit.) argumenta ainda que o estudo de caso é particularista, por focar-se em um fenômeno particular, descritivo, por se preocupar em descrever de forma rica e concisa 0 caso em estudo, e heurístico, uma vez que ilumina e amplia a compreensão do leitor a respeito do tópico em questão.

O estudo de caso também é particularmente atraente, segundo Merriam (1998) caso o interesse do pesquisador seja o processo desenvolvido ao longo do fenômeno. No caso desta pesquisa, a qual tem como base as ideias de avaliação como processo e não produto da aprendizagem, uma metodologia cujo foco é exatamente o decorrer da situação torna-se fundamental.

Com base em todas as considerações evidenciadas, entendo que, quando o pesquisador consegue abrir mão, ainda que momentaneamente, dos seus próprios valores para enxergar de forma global a cultura do meio no qual se inseriu, ele então adentra o outro fundamento norteador do estudo de caso exposto por Merriam (1998) e explicado por Van Lier (ibidem): o princípio holístico, segundo o qual todo o sistema de crenças, relações sociais, e padrões culturais do grupo devem ser levados em consideração pelo pesquisador, o qual precisa sempre buscar obter a visão mais ampla possível do contexto em questão.

Fetterman (1998) argumenta que apenas uma visão livre de julgamentos por parte do pesquisador abriria caminhos para a visão holística. Segundo o autor, ao discursar sobre os princípios da etnografia, os quais são também aplicáveis ao estudo de caso, o pesquisador deve suspender seus valores e crenças pessoais durante suas observações, para assim conseguir captar as sutilezas das interações, as quais se tornam imperceptíveis diante de juízos de valores. Entretanto, Fetterman (ibidem) reconhece que, apesar da necessidade de sua constante busca, a neutralidade total do pesquisador neste aspecto é utópica, uma vez que somos todos produtos da nossa própria cultura.

O princípio holístico também corrobora as ideias de Freebody (2003), pois este aponta que uma das características do estudo de caso, a qual é também compartilhada pela etnografia e pela pesquisa-ação, é que os 
resultados são apoiados em assertivas empíricas, as quais levam em consideração o conjunto completo que circunda o contexto observado. $\mathrm{Na}$ concepção de Fetterman (ibidem), é este princípio que possibilita ao pesquisador de campo vislumbrar além da noção imediata de um evento, pois ele entende que cada cena existe dentro de um contexto multifacetado e interrelacionado.

Diante do exposto, os preceitos do estudo de caso se fizeram necessários para esta pesquisa, visto que, para alcançar a real motivação do professor pesquisado, e as crenças que embasam suas ações no ambiente educacional, a minha permanência na sala de aula do participante foi fator crucial. Para compreender se e como as crenças observadas se moldam em ações eficazes para um ensino de sucesso, a própria pesquisa exigiu que eu adotasse uma postura êmica, através da observação participante, além de despir-me, à medida do possível, de pré-julgamentos para tentar alcançar uma visão holística do contexto que me circundou ao longo da pesquisa.

Assim, contemplei no estudo de caso, particularmente naquele intitulado interventivo - sobre o qual disserto na subseção seguinte - a metodologia de pesquisa que viabilizou os intuitos deste estudo.

\subsubsection{O Estudo de Caso Interventivo}

Faltis (1997) faz a distinção de dois tipos de estudo de caso: interpretativo e interventivo, sendo o foco do primeiro o fenômeno em si, enquanto o segundo visa, além de todos os preceitos presentes no primeiro, analisar se e quais efeitos a intervenção ocasionou nos participantes. Como já exposto na seção anterior, esta pesquisa é norteada por princípios interpretativistas. Entretanto, o modelo teórico de estudo de caso que melhor se adequa aos objetivos deste estudo é o de cunho interventivo, por prever a possibilidade de intervenções ao longo da pesquisa.

O caráter interventivo desta pesquisa oportunizou uma interferência guiada, uma vez observada a possibilidade de expor ao professor modelos, técnicas e instrumentos alternativos de avaliação, os quais poderiam vir a tornar o ensino ainda mais eficaz, motivador e dinâmico. Além disso, a modalidade também viabilizou a observância do momento pós-intervenção, 
possibilitando ao pesquisador verificar se esta ação surtiu ou não algum efeito no fenômeno analisado.

Desta forma, acredito que, à luz de todas as ponderações concebidas, é seguro afirmar que o estudo de caso interventivo se adéqua de maneira sem igual aos propósitos desta pesquisa, uma vez que o intuito da mesma foi não apenas observar e descrever as crenças de um professor de inglês no tocante à avaliação. Este estudo almejou ir além, aspirando conseguir propiciar o momento de reflexão necessário para a possível ressignificação de crenças propagadoras de um modelo de ensino que já não supre as necessidades atuais do ensino de inglês como LE (SCARAMUCCI, 1997).

Disponho, a seguir, sobre o contexto desta pesquisa e as motivações que ocasionaram a escolha deste.

\subsection{O CONTEXTO DA PESQUISA}

Segundo Goodson (1992 apud KUDIESS, 2005, p. 41), não se pode separar o professor de sua prática. Por este motivo, as pesquisas atuais buscam observar o professor dentro do contexto escolar, no qual o docente pode ser investigado tanto a partir das suas ações quanto da sua própria visão de mundo inferida pelo pesquisador.

lluminada pelo entendimento acima, a presente pesquisa foi desenvolvida em uma sala de aula de inglês de uma cooperativa de ensino de línguas estrangeiras do Distrito Federal, sobre a qual disserto na subseção seguinte.

\subsubsection{A Cooperativa}

Fundada em 1999, a cooperativa que abriu as portas para esta pesquisa iniciou as suas atividades em 2000, com aproximadamente 350 alunos distribuídos em duas unidades de ensino, localizadas em Ceilândia e Taguatinga Norte. Atualmente, a cooperativa conta com onze unidades 
espalhadas por todo o Distrito Federal, nas quais estudam aproximadamente 9.000 alunos, estando mais de $70 \%$ destes matriculados no curso de inglês.

O objetivo desta instituição é, de acordo com material fornecido em seu curso de noções de cooperativismo, "a democratização do ensino de língua estrangeira, a preparação do cidadão para o ingresso e/ou permanência no mercado de trabalho, bem como o desenvolvimento de projetos pedagógicos e socioculturais" (COOPERATIVA, Noções Básicas sobre Cooperativismo, p. 10).

A escola oferece cursos de inglês, francês e espanhol para públicos de todas as faixas etárias, ingressos a partir da primeira série, ou segundo ano escolar. Além disso, proporciona a possibilidade de intercâmbios culturais com países falantes das línguas trabalhadas e disponibiliza outros recursos, tais como plantões de dúvidas e acompanhamentos pedagógicos, além de cursos especiais para alunos que já concluíram o nível avançado dos idiomas ou possuem alguma necessidade específica.

No tocante ao espaço físico, como já mencionado, a escola conta com onze unidades espalhadas pela capital brasileira, as quais possuem as suas próprias especificidades para melhor atender o público da região na qual se localizam. Entretanto, apesar de variarem no tocante à metragem do espaço físico e na quantidade de salas de aula, todas possuem salas equipadas com TV e som, sala dos professores, sala de coordenação, secretaria e espaço para a realização de atividades coletivas com os alunos. Além disso, algumas unidades contam ainda com bibliotecas e salas de estudo.

No que concerne à sala de aula que recebeu esta pesquisa, a mesma se trata de uma turma do curso de inglês constituída por 16 alunos do primeiro nível do avançado (AD1). As aulas se desenvolvem durante quatro horas do período matutino do sábado. Portanto, discurso a seguir especificamente sobre o curso de inglês para o nível adulto, pois foi neste contexto, conforme explicitado, que o presente estudo se realizou.

Todos os níveis do curso de inglês contam com 36 encontros semestrais e a duração das aulas muda de acordo com os níveis. As aulas podem ocorrer duas vezes por semana, com duração de 1 hora de 15 minutos cada, no caso dos níveis básicos, e 1 hora e 50 minutos cada, nos níveis intermediários e avançados. Há também a possibilidade de aulas duplas uma única vez por semana, nas sextas ou nos sábados, sendo que, neste caso, as turmas de 
nível básico possuem a carga horária de 2 horas e 30 minutos, enquanto as de nível intermediário ou avançado contam com 4 horas de aula cada. Há a previsão de turmas em todos os turnos, matutino, vespertino e noturno durante os dias da semana (de segunda à sexta) e nos turnos matutino e vespertino aos sábados.

A duração total do curso de inglês para adultos é de cinco anos e seis meses, os quais são divididos em onze ciclos semestrais, cada um constituindo um nível completo do ensino da língua, e através dos quais o aluno vai do básico ao avançado do idioma. Os ciclos desenvolvidos na Cooperativa são classificados conforme o quadro abaixo.

QUADRO 2 - Nomenclatura, Ciclos e Correspondência dos Cursos

\begin{tabular}{|c|c|c|}
\hline Nomenclatura do Nível & Ciclo & $\begin{array}{l}\text { Correspondência com o } \\
\text { Quadro de Referências } \\
\text { Comum Europeu }\end{array}$ \\
\hline $1 \mathrm{~A}$ & \multirow[t]{3}{*}{ Básico } & \multirow[t]{3}{*}{$\mathrm{A} 1$ e A2 } \\
\hline 1B & & \\
\hline $2 \mathrm{~A}$ & & \\
\hline 2B & \multirow{2}{*}{ Pré - Intermediário } & \multirow{2}{*}{ A2 e B1 } \\
\hline 3A & & \\
\hline 3B & \multirow[t]{2}{*}{ Intermediário } & \multirow[t]{2}{*}{ B1 e B2 } \\
\hline 4A & & \\
\hline 4B & \multirow{2}{*}{ Pós - Intermediário } & \multirow[t]{2}{*}{ B2 } \\
\hline $5 \mathrm{~A}$ & & \\
\hline AD1 & \multirow[t]{2}{*}{ Avançado } & \multirow[t]{2}{*}{ C1 } \\
\hline AD2 & & \\
\hline
\end{tabular}


Cada semestre constitui um ciclo fechado do curso, sendo este constituído por dois bimestres letivos. Ao final de cada bimestre, os alunos recebem uma média aritmética, fruto das provas e atividades desenvolvidas ao longo do bimestre em questão, a qual pode chegar ao máximo de 100 pontos. Assim, para ser aprovado no nível, o aluno precisa ter, na somatória das médias dos dois bimestres, a nota mínima de 60 pontos e, caso não consigam esta, o aluno deverá refazer o nível, pois não existe a previsão de recuperação.

O livro didático utilizado no curso adulto é o English File Third Editon, da editora Oxford, pois o mesmo se propõe a trabalhar as quatro habilidades linguísticas de forma conjunta, o que é um dos objetivos do ensino de inglês na instituição em questão. Outra característica do material é a liberdade que o mesmo proporciona à escola no que diz respeito ao tempo de utilização, pois o cronograma do livro não vem estruturado, ficando a critério da instituição distribuir as lições da forma que melhor convier aos propósitos do seu programa de curso. O material se intitula comunicativo e conta ainda com amplo suporte de exercícios online disponíveis para alunos e professores, além da presença de CD interativo, livro de tarefas, livro de suporte e instruções para o professor, atividades fotocopiáveis de vocabulário, gramática e uso da língua e outros recursos que viabilizam a utilização do inglês em situações autênticas de uso da língua. O English File Third Edition possui grande grau de aceitação entre os professores da cooperativa.

Além da utilização do livro didático, todos os níveis, exceto os Avançado 1 e 2, preveem a leitura de um livro paradidático em seu calendário, o qual será utilizado também na avaliação dos alunos, através de provas, seminários ou redações.

A escolha desta instituição de ensino em particular deveu-se a alguns fatores específicos, dentre eles, o apoio à pesquisa acadêmica, encontrado tanto entre os coordenadores quanto entre os professores da escola. Segundo Flick (2004), um dos problemas que o pesquisador pode enfrentar refere-se ao acesso às instituições, tendo em vista que a pesquisa representa uma intrusão na realidade vivida pelas escolas. O possível desequilíbrio causado pela pesquisa é fator determinante na recusa de muitas instituições em abrirem suas portas para o pesquisador. Diante destas considerações, acredito que a criação e a manutenção de um relacionamento colaborativo com uma escola 
que já se propõe aberta à pesquisa são não só mais fácil, como também passível de maior propensão para diálogo entre o pesquisador e todos os participantes envolvidos.

Por fim, há um interesse especial da minha parte nesta escola, uma vez que trabalho atualmente na mesma tanto como professora de língua inglesa como coordenadora de alguns níveis deste idioma. Assim, a possibilidade de poder, ainda que minimamente, contribuir com o contínuo processo de aprimoramento desta Cooperativa é motivo de satisfação para mim.

A seguir, apresento o participante da pesquisa e o motivo pelo qual o mesmo foi selecionado para este estudo.

\subsection{O PARTICIPANTE DA PESQUISA}

Um professor da Cooperativa foi convidado a participar desta pesquisa. Ao fazer o convite, levei em consideração o tempo que o mesmo atua como docente, o tempo que trabalha na instituição na qual a pesquisa foi conduzida, o nível de fluência da língua inglesa que ele apresenta, a capacidade que possui para ministrar aulas para diversos níveis e audiências e, por fim, a disponibilidade e abertura do professor para ser participante de uma pesquisa que será conduzida ao longo de todo o semestre.

Segundo Freebody (2003), uma das questões que envolvem decisões críticas nas pesquisas é o da escolha dos participantes. O questionamento sobre a disponibilidade e apropriação dos participantes escolhidos, bem como o envolvimento dos mesmos nas atividades deve ser levado em consideração no momento da escolha.

Observados os argumentos do autor, optei por realizar a pesquisa com um colega, o qual me proporcionou melhor receptividade e com o qual desfrutei de maior liberdade para adentrar profundamente as questões que foram levantadas ao longo da pesquisa. Entendo que a ressignificação de crenças pode se constituir em um processo constrangedor e extremamente desafiador, uma vez que o professor terá as suas crenças e práticas expostas a um olhar externo, situação que pode gerar inseguranças sobre o seu pensar e proceder 
em sala de aula. Destarte, a tolerância e aceitabilidade de um colega me ajudou a eliminar alguns problemas que poderiam ter se contraposto ao bom andamento da pesquisa.

\subsubsection{Perfil do Participante}

Segundo a narrativa coletada por escrito no início desta pesquisa, sobre a qual discorro nas seções seguintes, o professor convidado para participar deste estudo possui 34 anos de idade e, sendo desde cedo apaixonado pela língua inglesa, ele começou seus estudos do idioma sozinho, aprendendo através de filmes legendados, músicas e todos os outros mecanismos que se apresentavam a ele como passíveis de serem estudados. Assim, quando procurou um curso formal de inglês pela primeira vez, foi nivelado para o Avançado, não demorando muito tempo para concluir o curso e começar a ministrar aulas do idioma.

Licenciado pela Universidade de Brasília (UnB) em Letras Inglês, ele possui ainda diploma superior em PBSL - Português do Brasil como Segunda Língua - e formação em artes, além de ter ingressado recentemente no Mestrado em Linguística também na UnB. Atuante como professor de inglês desde os seus 20 anos, ele já ministrou aulas do idioma em diversas instituições de ensino do Distrito Federal, e integra, desde 2011, o quadro de cooperados efetivos da instituição em questão, na qual ministra aulas de inglês para todos os níveis e idades previstos nos cursos oferecidos pela escola.

Além de professor, o participante já atuou como coordenador de cursos preparatórios para a prova do Rio Branco, como examinador de testes de proficiência, a citar o FCE (First Certificate in English) e o CAE (Cambridge English: Advanced), e, atualmente, exerce também a função de assessor pedagógico na cooperativa em que trabalha, auxiliando no desenvolvimento de novos cursos, ministrando orientações para os novos professores da instituição e dando suporte pedagógico a todos os professores da escola.

Ao ser convidado para participar desta pesquisa, o professor se mostrou animado e disposto, considerando esta uma oportunidade de conhecer um pouco mais sobre a sua própria prática docente, além de contribuir para futuras pesquisas na LA. 
Após discorrer a respeito do participante desta pesquisa, exponho, na seção que se segue, os métodos e os instrumentos que serão utilizados para a realização da coleta de registros e a razão pela qual os mesmos serão adotados.

\subsection{OS INSTRUMENTOS DA COLETA DE REGISTROS}

Bauer e Aarts (2002, p. 39) explicitam que "toda pesquisa social empírica seleciona evidências para argumentar e necessita justificar a seleção que é a base de investigação, descrição, demonstração, prova ou refutação de uma afirmação específica".

Com base na explanação proposta por Bauer e Aarts (ibidem), alguns instrumentos e métodos foram selecionados, visando-se obter a triangulação dos dados, a qual foi definida por Wiersma como "a procura pela convergência da informação com achados ou conceitos comuns" (op. cit., 1995, p. 264, apud FREEBODY, 2003, p.77. Tradução minha). Segundo Duff (2008), a triangulação de dados amplia a validade do estudo, uma vez que permite a observação do problema sob diferentes perspectivas, ocasionando uma visão mais vasta e complexa do contexto em questão.

Assim, nesta pesquisa os instrumentos e técnicas utilizados para a coleta de registros foram: uma narrativa por escrito, uma entrevista semiestruturada, observações de aulas, notas de campo do pesquisador, gravações das aulas em áudio e vídeo, duas sessões de discussão e duas sessões de visionamento. Elucido a seguir os princípios destes instrumentos:

a. Narrativas escritas - as narrativas escritas, segundo Clandinin e Connelly (2000), têm sido amplamente utilizadas na pesquisa qualitativa, como forma de acessar experiências de professores, tanto nas dimensões pessoais quanto profissionais. Esta concepção endossa o entendimento de Vieira-Abrahão (2006), que denomina as narrativas como autorrelatos. As autoras acreditam que este é um instrumento bastante eficaz na pesquisa sobre crenças, visando identificar as mesmas e entender suas origens. 
Desta forma, foi solicitada ao professor participante da pesquisa uma narrativa escrita sobre os caminhos que ele percorreu desde a posição de aluno de língua estrangeira até a sua prática consolidada como professor, visando a obtenção de elementos que me permitissem não apenas traçar 0 perfil do professor, conforme demonstrado da seção anterior, mas também conhecer mais profundamente o que o participante pensa sobre suas experiências pessoais e profissionais, além da possibilidade de inferir algumas das crenças que ele carrega consigo a datar dos tempos em que era aprendiz de inglês.

Não houve um roteiro pré-estabelecido para a narrativa, sendo que o professor teve liberdade para escrever sobre o que lhe fosse mais interessante relatar. Esta narrativa foi solicitada no início da pesquisa, antes dos outros instrumentos serem aplicados. Entretanto, ela somente foi entregue, por e-mail, após a realização da entrevista individual semiestruturada, sobre a qual disserto a seguir.

b. Entrevista individual semiestruturada - A importância da entrevista, bem como as dificuldades advindas da mesma, são evidenciadas nas palavras de Silveira (2012, p.139-140)

\begin{abstract}
(a entrevista é) um jogo interlocutivo em que um/a entrevistador/a "quer saber algo", propondo ao/à entrevistado/a uma espécie de exercício de lacunas a serem preenchidas... Para esse preenchimento, os/as entrevistados/as saberão ou tentarão se reinventar como personagens, mas não personagens sem autor, e sim, personagens cujo autor coletivo sejam as experiências culturais, cotidianas, os discursos que os atravessaram e ressoam em suas vozes. Para completar essa "arena de significados", ainda se abre espaço para mais um personagem: o pesquisador, o analista, que fazendo falar de novo tais discursos - os relerá e os reconstruirá, a eles trazendo outros sentidos.
\end{abstract}

Conforme Nunan (1992), entrevistas orais têm sido amplamente utilizadas como instrumentos de pesquisa em LA, sendo as entrevistas semiestruturadas as mais aplicadas pelos pesquisadores que trabalham com a pesquisa interpretativa, por estas oferecerem um certo grau de controle, combinado a um dado nível de flexibilidade. 
Para Rosa e Arnoldi (2006), as entrevistas semiestruturadas permitem um questionamento mais profundo e subjetivo, e, pressupõem um roteiro de tópicos selecionados. Por não possuírem uma estrutura rígida, estas entrevistas possibilitam que os participantes articulem seus pensamentos e inclinações sobre os tópicos abordados de forma mais natural, o que corrobora os estudos de Vieira-Abrahão (2006). Rosa e Arnoldi (ibidem) afirmam ainda que este tipo de entrevista frequentemente objetiva, dentre outros assuntos, a inferência de crenças dos professores, o que faz a mesma ser de fundamental relevância para esta pesquisa.

Desta forma, foi aplicada uma única entrevista semiestruturada para o professor, também no início da pesquisa, como segundo instrumento de coleta de registro. Esta entrevista teve a duração de uma hora e sete minutos e foi gravada em áudio.

c. Observação das aulas - Nas palavras de Vieira-Abrahão (ibidem, p.225), "a observação de aulas possibilita que os pesquisadores documentem sistematicamente as ações $e$ as ocorrências que são particularmente relevantes para suas questões e tópicos de investigação".

lluminada por este entendimento, nesta pesquisa as observações de aulas possuíram o intuito de inferir as crenças sobre ensino e aprendizagem de LE do professor, bem como identificar suas origens e as influências das mesmas nas decisões tomadas em sala de aula.

Além disso, as observações de aula, as quais ocorreram ao longo do primeiro e do segundo bimestre letivo do ano de 2015, possibilitaram-me observar como algumas das crenças do professor se constituíram em ações no cenário escolar e de que forma as mesmas interferiram nas questões avaliativas.

d. Notas de campo do pesquisador - Para Bogdan e Biklen (1998), o êxito dos estudos que envolvem observação dependem de notas de campo precisas e detalhadas, que terão por objetivo o registro das observações, comentários e análises feitas. Segundo Fetterman (1998), são as notas de campo que constituem tanto a fase inicial para a análise de dados quanto o arcabouço necessário para profundas investigações posteriores. $O$ autor considera ainda 
que as notas de campo devem ser feitas durante o trabalho em campo e ao fim de cada dia, para evitar comprometer a autenticidade das mesmas.

Dessa forma, nesta pesquisa, as notas de campo foram elaboradas ao longo e após todas as aulas observadas, visando o registro acurado e objetivo das informações apresentadas sobre avaliação.

e. Gravação das aulas em áudio e vídeo - As gravações em áudio e vídeo visam, segundo Veira-Abrahao (2006), o registro detalhado das ações e interações em sala de aula. Como pesquisadora, acredito na vital necessidade da utilização das gravações em minha pesquisa, pois entendo que, ainda que observações de aulas e anotações de campo sejam elaboradas, a compreensão do todo exige e pressupõe um retorno a determinadas situações que somente serão possíveis através da gravação das mesmas, haja vista a riqueza de informações apresentadas em uma sala de aula, as quais não se permitem serem totalmente captadas por notas de campo.

Para Almeida Filho (2007, p.23)

\begin{abstract}
A gravação em áudio ou vídeo de uma sequência de aulas típicas registra de forma duradoura o processo de ensinar em construção e por isso permite, na revisitação, nos revisionamentos e nas reaudições das aulas, o flagrar de evidências e contra-evidências para a construção de uma interpretação da abordagem em fluxo.
\end{abstract}

Além disso, Fetterman (1998) afirma que os gravadores proporcionam maior liberdade aos pesquisadores, que não precisam se prender excessivamente aos registros manuais, e podem atentar de forma mais livre à interação com os participantes. Assim, com a permissão dos participantes, gravei em áudio e em vídeo as quatro horas de cada uma das quatorze aulas duplas observadas. É importante ressaltar, entretanto, que a primeira aula observada não foi gravada, uma vez que foi o momento no qual conversamos com os alunos e pedimos a permissão para tanto. As gravações me possibilitaram reacessar as aulas sempre que se fez necessário.

Entretanto, seguindo as orientações de Rosa e Arnoldi (2006), mantive os gravadores e a câmera discretamente posicionados, tanto no proceder da 
entrevista, quanto nas observações de aula, entendendo a necessidade de não causar constrangimento ou desconforto aos participantes.

f. Sessões de Discussão - Também conhecidas como sessões reflexivas, elas permitem, dentre outras coisas, que pesquisador e participante discutam sobre os dados levantados e teçam considerações a respeito do andamento da pesquisa. Assim, com o intuito de gerar momentos que propiciassem a reflexão, foram desenvolvidas duas sessões de discussão, uma no final do primeiro bimestre de 2015 e a outro no final do semestre. Ambas as sessões foram gravadas em áudio, sendo que a primeira teve a duração quarenta e sete minutos, enquanto a segunda teve a duração de uma hora e treze minutos.

A primeira sessão de discussão serviu primordialmente para a discussão dos textos ${ }^{4}$ sugeridos pela pesquisadora ao participante da pesquisa. A necessidade de se sugerir as leituras ao professor deu-se pelo entendimento de que a falta de acesso à literatura na área de ensinoaprendizagem de línguas é, segundo Barcelos (2006) e Araújo (2006), um dos fatores que contribui para a falta de reflexão e mudança de atitude dos professores de LE. Os cinco textos sugeridos compreendiam assuntos referentes à avaliação e foram entregues ao professor duas semanas antes da primeira sessão de discussão, para que ele pudesse ler e refletir sobre os mesmos.

A segunda sessão ocorreu devido à demanda do professor participante da pesquisa, o qual, após o término das observações de aula, solicitou um momento para dialogar sobre as novas perspectivas avaliativas que ele havia se proposto a pôr em prática.

g. Sessões de Visionamento - Nas palavras de Vieira-Abrahão (ibidem, p.227)

\footnotetext{
${ }^{4}$ Os textos sugeridos para a leitura foram: 1) O professor e a avaliação em sala de aula (GATTI, 2003); 2) O professor avaliador: sobre a importância da avaliação na formação do professor de língua estrangeira (SCARAMUCCI, 2006); 3) Crenças sobre avaliação em língua inglesa: um estudo de caso a partir das metáforas no discurso de professores em formação (BARATA, 2006, p. 28-40); 4) A avaliação na escola: um histórico de exclusão social-escolar ou uma proposta sociocultural para a inclusão? (FIDALGO, 2006); e 5) O desafio de avaliar em língua estrangeira (PONTES; SOARES, 2010).
} 
As sessões de visionamento, também chamadas por outros autores de sessões-reflexivas, envolvem a exposição das gravações em vídeo das aulas observadas aos participantes, professores e alunos, esperando levantar, com tal exposição, a perspectiva dos actantes sobre suas próprias ações e provocar a conscientização dos mesmos sobre o seu fazer.

lluminada por este entendimento, as sessões de visionamento, para o intuito desta pesquisa, foram desenvolvidas em dois momentos: 1) no final do primeiro bimestre de 2015, quando a pesquisadora já havia desenvolvido parte do trabalho de observação de aulas, coleta de registro e análise de dados da primeira parte do curso, e 2) no final do primeiro semestre letivo de 2015. Ambas as sessões foram gravadas em áudio, sendo que a primeira teve a duração de duas horas, enquanto a segunda teve a duração de duas horas e quinze minutos. A partir do momento que o participante da pesquisa teve a oportunidade de revisitar suas crenças, ele obteve também a oportunidade de repensar suas ações em sala de aula.

Na sessão a seguir, apresento os procedimentos para a análise dos dados.

\subsection{PROCEDIMENTOS PARA A COLETA DE REGISTROS}

A pesquisa foi realizada em cinco momentos, sendo o primeiro o período de coleta de registros e análise dos dados, através do colhimento da narrativa, da aplicação da entrevista, e da observação das aulas do primeiro bimestre de 2015; em seguida, houve um momento de intervenção, através de uma sessão de discussão, na qual a pesquisadora discutiu com o professor a respeito dos textos sobre avaliação que Ihe haviam sido entregues no final do primeiro bimestre de aulas, além da realização da primeira sessão de visionamento; a terceira etapa se deu através da observação das aulas no período pós-intervenção, visando a averiguação da existência de indícios de mudança de atitudes ocasionada pelas reflexões advindas da sessão de visionamento e das leituras sugeridas; o quarto momento da pesquisa se realizou através de uma segunda sessão de visionamento com o professor, na 
qual foram trabalhadas todas as circunstâncias observadas na terceira etapa. Por fim, a quinta e última etapa da pesquisa, não prevista originalmente, se tratou de uma sessão de discussão, ocasionada pela demando do próprio professor, conforme explicitado mais detalhadamente nas seções que seguem.

O quadro a seguir demonstra todos momentos do estudo:

\section{QUADRO 3: ETAPAS DA PESQUISA}

\begin{tabular}{|c|c|c|}
\hline ETAPA & CRONOGRAMA & ATIVIDADES A SEREM DESENVOLVIDAS \\
\hline \multirow[t]{2}{*}{$1^{\circ}$ Momento } & \multirow[t]{2}{*}{$\begin{array}{l}\text { De fevereiro a } \\
\text { abril de } 2015 \text {. }\end{array}$} & $\begin{array}{l}\text { Coleta da Narrativa (NE). } \\
\text { Aplicação da Entrevista Semiestruturada (ES) } \\
\text { Observação e Gravação em áudio de aulas do primeiro } \\
\text { bimestre letivo, acompanhadas da produção das notas de } \\
\text { campo (OA1) }\end{array}$ \\
\hline & & Gravação das aulas referentes à avaliação em vídeo. \\
\hline \multirow[t]{2}{*}{$2^{\circ}$ Momento } & \multirow[t]{2}{*}{ Abril de 2015.} & $\begin{array}{l}\text { Leitura de Textos Teóricos por parte do professor } \\
\text { participante. }\end{array}$ \\
\hline & & $\begin{array}{l}\text { Primeira Sessão de Discussão (SD1). } \\
\text { Primeira Sessão de Visionamento (SV1). }\end{array}$ \\
\hline $3^{\circ}$ Momento & $\begin{array}{l}\text { De abril a junho } \\
\text { de } 2015 \text {. }\end{array}$ & $\begin{array}{l}\text { Observação e gravação em áudio das aulas do segundo } \\
\text { bimestre letivo, acompanhadas da produção das notas de } \\
\text { campo (OA2) }\end{array}$ \\
\hline $4^{\circ}$ Momento & Junho de 2015. & Segunda Sessão de Visionamento (SV2). \\
\hline $5^{\circ}$ Momento & $\begin{array}{l}\text { Setembro de } \\
2015 .\end{array}$ & Segunda Sessão de Discussão (SD2). \\
\hline
\end{tabular}

(Quadro meu)

O primeiro instrumento de coleta de registro foi a narrativa por escrito $(\mathrm{NE})$, a qual foi solicitada ao participante da pesquisa antes de se iniciarem as observações de aula. Os dados obtidos através deste instrumento permitiram à pesquisadora não apenas traçar o perfil do participante, mas também inferir 
algumas de suas crenças, conforme será explicitado no próximo capítulo. Em seguida, no início das observações das aulas, foi realizada uma entrevista semiestruturada (ESE) com o participante. As aulas observadas possuem notas de campo elaboradas pela pesquisadora e foram gravadas em áudio e vídeo. A utilização de todos estes instrumentos se dá pelo entendimento de que $\mathrm{o}$ uso de diferentes modalidades de relatos orais e escritos permite, segundo Vieira-Abrahão (2006), mapear e entender de forma mais clara e objetiva as crenças dos professores, além de permitir a triangulação dos dados.

No final do primeiro bimestre das aulas, entreguei ao professor participante alguns textos selecionados que apresentaram a literatura corrente sobre crenças e avaliação, para uma discussão futura com a pesquisadora na primeira sessão de discussão (SD1). Após esta, prosseguimos com a primeira sessão de visionamento (SV1), para a qual foram selecionados momentos em áudio e vídeo, bem como trechos das transcrições das aulas e notas de campo do pesquisador que dizem respeito às ocasiões nas quais o tema avaliação, especialmente quando pautadas em crenças, forem observadas.

Após a intervenção, continuei com as observações das aulas durante todo o segundo bimestre, adotando os mesmos procedimentos de gravação do primeiro bimestre, para averiguar se houve algum indício de mudança perceptível na prática do professor após o momento de reflexão.

Assim, passadas as observações das aulas do segundo bimestre, no final do semestre letivo, e em posse de todos os registros coletados, bem como da análise tanto da intervenção como das aulas pós-intervenção, foi realizada uma última sessão de visionamento (SV2), através da qual pudemos discutir os desdobramentos do bimestre e os reflexos das discussões realizadas ao longo da pesquisa.

Por fim, após o término de todas as etapas propostas no desenho inicial da pesquisa, o professor me procurou para discutir algumas questões, momento este que se consolidou na segunda sessão de discussão deste estudo (SD2). Depois de haver iniciado outro semestre letivo com a mesma turma que abrigou esta pesquisa, a qual se encontrava então já no nível avançado 2, o professor me convidou para discursar a respeito de como estava desenvolvendo suas práticas avaliativas depois de findadas as observações de aula e como os seus alunos estavam respondendo às mesmas, além de pedir 
algumas orientações a respeito de caminhos alternativos para proceder com certas atividades.

\subsection{PROCEDIMENTOS PARA A ANÁLISE DOS DADOS}

A análise realizada neste estudo foi uma análise de conteúdo. Após o primeiro e o segundo momentos da pesquisa, detalhados na seção anterior, a pesquisadora identificou as crenças do professor participante através da triangulação dos dados presentes na narrativa, na entrevista semi-estruturada, nas observações das aulas do primeiro bimestre observado - levando em consideração as gravações feitas em áudio e em vídeo, bem como as notas de campo da pesquisadora - na primeira sessão de discussão e na primeira sessão de visionamento. Após descrever e agrupar estas crenças, as mesmas foram analisadas interpretativamente sob a perspectiva da relação entre as crenças do professor sobre avaliação, sua fala e suas tomadas de decisão em sala de aula sobre o tema.

O terceiro, quarto e quinto momentos da pesquisa serviram como insumo para a análise final deste estudo, a qual se preocupou em observar de que forma os momentos de intervenção propostos ao longo da pesquisa influenciaram o falar e o agir do professor no que tange à avaliação. Para tanto, as crenças obtidas no primeiro momento da análise, bem como os procedimentos avaliativos adotados no primeiro bimestre de aula, foram contrastados ao proceder no momento pós-intervenção e à sua fala na última sessão de visionamento e na última sessão de discussão. Os indícios de ressignificação ou de permanência das crenças iniciais, levantados a partir desta segunda triangulação de dados, foram descritos, agrupados e analisados interpretativamente com base não apenas no que foi realizado pelo professor em sala de aula no segundo bimestre, mas também no relatado per ele nas últimas sessões reflexivas.

O quado abaixo demonstra sucintamente os procedimentos de análise adotados nesta pesquisa. 


\section{QUADRO 4: PROCEDIMENTOS PARA A ANÁLISE DOS DADOS}

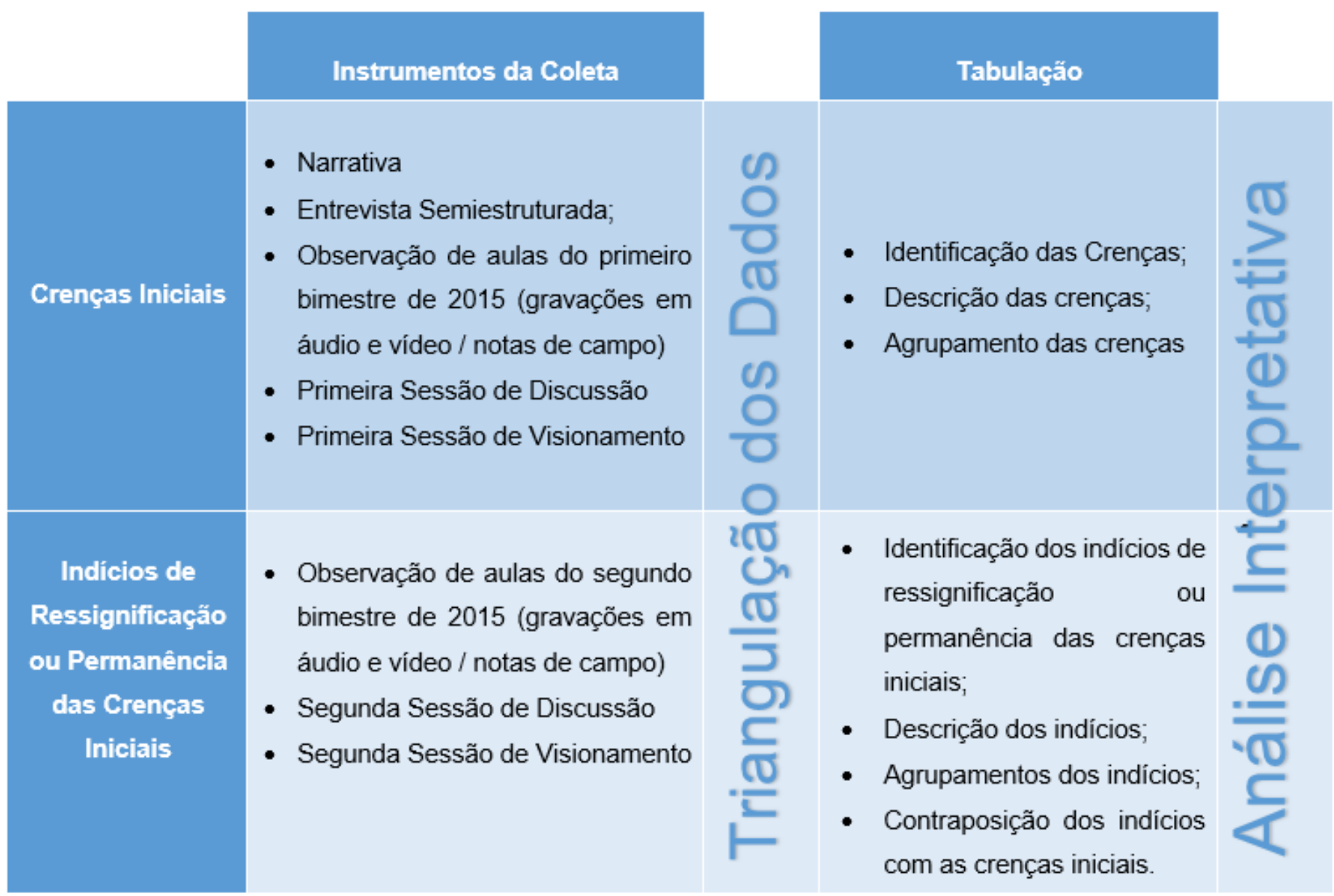

(Quadro meu)

Após ter discursado a respeito dos procedimentos para colheita de registro e análise dos dados, passo, a seguir, para as considerações éticas que regem esta pesquisa.

\subsection{CONSIDERAÇÕES ÉTICAS}

Para Moura Filho (2000), a pertinência da conduta ética do pesquisador tornou-se preceito essencial no âmbito da pesquisa. Entretanto, a definição de ética na pesquisa é profícua e chega ao limiar da ambiguidade.

Dessa forma, visando aclarar possíveis imprecisões, declaro que os princípios éticos que regem esta pesquisa seguem a orientação dos preceitos sugeridos por Punch (1994), segundo o qual problemas éticos e morais 
geralmente devem ser resolvidos situacionalmente, não havendo um manual certeiro de como ser ético na pesquisa, uma vez que o contexto em questão providenciará o caminho a ser seguido.

Neste trabalho, as fundamentações éticas adotadas possuem, dentre outros, o intuito de estabelecer um relacionamento legítimo com todos os envolvidos na pesquisa. Punch (ibidem), em seu texto sobre política e ética na pesquisa qualitativa, discorre sobre o direito dos participantes de serem informados não apenas que estão sendo pesquisados, mas também sobre a natureza da pesquisa. O consentimento ciente dos participantes do estudo é um dos pressupostos éticos para a continuidade do mesmo.

No tocante à transparência da pesquisa, Schüklenk (2005, p. 36.Tradução minha) afirma que:

\footnotetext{
Após serem voluntariamente informados e esclarecidos, a concordância dos participantes com a pesquisa é uma forma de expressarem que os propósitos da mesma são compartilhados e que não são apenas instrumentos para um fim, mas parte essencial do processo.
}

À luz dessas orientações, eu redigi um documento formal, o qual foi entregue ao coordenador em vigência da unidade (vide Apêndice A) que abrigou este estudo, para que o mesmo autorizasse a realização da pesquisa nas dependências do Cooperativa em questão.

Além deste, outro documento, o Termo de Consentimento, foi elaborado e endereçado ao professor pesquisado (vide Apêndice B), com o intuito de elucidar não apenas os propósitos desta pesquisa, mas também os instrumentos de coleta de dados que seriam utilizados e a metodologia empregada neste estudo. Entendo que apenas diante de tais esclarecimentos 0 participante pôde se sentir confortável para aceitar ou não cooperar com a pesquisa, além estar de suficientemente informado para se tornar coexecutor da mesma.

Por fim, um terceiro documento de autorização foi entregue aos alunos que constituem a turma que observada (vide Apêndice $C$ ). Entendo que apesar do foco desta pesquisa não recair sobre os aprendizes, a participação dos mesmos, seja através das notas de campo da pesquisadora, das imagens ou 
do áudio gravados, reverberou em todo o estudo e, portanto, a autorização dos mesmos se fez necessária.

A privacidade e a confidencialidade dos envolvidos na pesquisa são outras questões éticas fundamentais. Punch (ibidem) afirma que há um sentimento geral entre os pesquisadores de campo de que os locais e os participantes da pesquisa não devem ser identificados, nem ser passíveis de danos ou constrangimentos advindos da pesquisa. Por este motivo, o nome do participante da pesquisa, bem como de seus alunos, do coordenador da unidade e da instituição de ensino permanecem em sigilo.

Por fim, entendida a particular relevância dos princípios éticos no tocante a pesquisas que abarcam o lidar com seres humanos, o que é o caso deste estudo, posicionei-me com o profissionalismo e atenção propostos por Fetterman (1998), os quais, segundo o autor, são capazes de demonstrar o profundo respeito, apreço e consideração do pesquisador pela cultura e, consequentemente, pelas pessoas que o receberam para a pesquisa.

Havendo discorrido sobre os princípios metodológicos que regem este estudo, passo, a seguir, para a análise e discussão dos dados. 


\title{
4 RESULTADOS E DISCUSSÃO DOS DADOS
}

\author{
Ontem eu era inteligente, \\ queria mudar o mundo. \\ Hoje eu sou sábio, \\ estou mudando a mim mesmo.
}

Autor desconhecido

Este capítulo exibe a análise dos dados e os resultados da pesquisa, estando dividido em três seções, cada uma se propondo a responder uma pergunta de pesquisa.

Assim, a primeira seção intenta responder a primeira pergunta norteadora deste estudo: Quais são as crenças do professor participante no que tange a avaliação e de que forma essas crenças se relacionam às tomadas de decisões do professor em sala de aula? Essa discussão possui como alicerces os dados coletados na narrativa escrita (NE), na entrevista (EM), nas aulas observadas ao longo do primeiro bimestre (OA1), na primeira sessão de discussão (SD1) e na primeira sessão de visionamento (SV1), ambas realizadas imediatamente após o término do primeiro bimestre de aulas de 2015.

A segunda seção procura trazer elucidações sobre a segunda pergunta de pesquisa: Como momentos guiados de reflexão podem contribuir para a ressignificação de crenças? A sustentação dos dados expostos nesta sessão encontra-se nas duas sessões de visionamento, uma ocorrida no final do primeiro bimestre de 2015 (SV1) e a outra ao término das observações de aula (SV2), na sessão de discussão realizada no final do primeiro bimestre (SD1) de 2015 e nas observações de aula do segundo bimestre do mesmo ano (OA2).

A terceira seção lança o olhar sobre a terceira pergunta norteadora: Qual impacto esta pesquisa teve sobre as crenças e práticas do professor participante? A última sessão de visionamento (SV2) fundamenta este momento do estudo, bem como uma segunda sessão de discussão (SD2) e o convite para uma orientação com os novos professores da instituição, ambas 
atividades à princípio não previstas, provenientes da demanda do professor participante em abrir uma nova possibilidade para refletir, dialogar e conhecer mais alternativas para práticas avaliativas.

Por fim, a última seção deste capítulo elabora uma síntese de todos os achados encontrados e discutidos no mesmo.

Passo a seguir ao levantamento e discussão das crenças do professor participante da pesquisa no que tange a avaliação.

\subsection{LEVANTAMENTO E DISCUSSÃO DAS CRENÇAS}

A narrativa e a entrevista realizadas no início da pesquisa, as aulas observadas ao longo do primeiro bimestre de 2015 e as sessões de discussão e de visionamento ocorridas ao término do mesmo expuseram tanto a fala quanto a prática do professor participante no que diz respeito aos aspectos concernentes à avaliação.

Estes momentos também possibilitaram perceber que o professor carrega crenças não apenas sobre a sua prática docente, mas também sobre a visão dos alunos no que diz respeito às atividades avaliativas. Essas crenças foram divididas em dois conjuntos: 1) Como o professor percebe suas próprias práticas avaliativas, os instrumentos avaliadores e a avaliação em si; e 2) Como o professor acredita que os alunos concebem a avaliação.

Passo a seguir à análise e discussão das crenças contidas na primeira categoria.

\subsubsection{Como o professor percebe suas próprias práticas avaliativas, os instrumentos avaliadores e a avaliação em si.}

Neste bloco de crenças, apresento aquelas que se referem especificamente à visão do professor participante no que concerne à sua própria condição como professor-avaliador, além da maneira como ele percebe os instrumentos que utiliza e o ato de avaliar em si. 
As crenças levantadas nesta categoria foram:

a) É importante negociar os processos avaliativos com os alunos. Esta crença foi inferida a partir da prática e da fala do professor. No dia 21 de fevereiro de 2015, primeiro dia de aula observado - correspondente ao segundo dia de aula do bimestre - o professor recapitulou as negociações do semestre discutidas com os alunos na aula anterior.

Primeiramente, eles discutiram como o professor deveria corrigir a oralidade dos alunos, sendo que todos concordaram que os erros de pronúncia, vocabulário e gramática poderiam ser corrigidos individualmente no momento em que ocorressem, caso não atrapalhasse o fluir das ideias do falante, ou posteriormente, através de uma explicação coletiva no quadro. Outra negociação girou em torno da data de entrega da redação, a qual poderia ser escolhida pelos alunos dentre as datas sugeridas pelo professor. $\mathrm{O}$ participante da pesquisa estabeleceu que após a data combinada, as redações não seriam mais aceitas.

O professor explicou ainda que dever de casa é responsabilidade do aluno e, consequentemente, ele não checaria quem o fez e não atribuiria nenhum tipo de pontuação ao mesmo. Por fim, o professor informou que é sua prática comum corrigir apenas alguns exercícios pontuais do workbook, haja vista o calendário apertado do nível em questão. Entretanto, alguns alunos pediram para que o professor corrigisse todos os exercícios, pois ele sempre acrescentava algo durante as explicações e as questões eram importantes para a prova. Outros alunos, porém, não concordaram e disseram que preferiam que apenas exercícios pontuais fossem corrigidos. Após uma discussão, todos consentiram em se corrigir apenas os exercícios do workbook nos quais os alunos tivessem dúvidas. Além da prática do professor, esta crença também está presente no seu discurso, uma vez que na entrevista realizada antes do início das aulas, no dia 26/02/2015, ele argumentou que

[1] um bom professor tem que ouvir os alunos / assim (+) ele tem que ter uma sensibilidade (.) é::: em relação aos alunos que:: sobre o qual $(+)$ né $(+)$ ele tá ali nessa responsabilidade de levar o conhecimento [...] eu acho que ter uma mente aberta ter uma sensibilidade em 
relação ao aluno / eu acho que o professor tem que estudar sempre, tem que tá antenado sobre o que está acontecendo no mundo (...) (EN)

Foi possível também constatar esta crença através do extrato a seguir, retirado da sessão de discussão ocorrida após o final do primeiro bimestre, no dia 28/04/2015.

[2] Professor: [...] por exemplo, a questão de colocar o listening como uma questão de:: de:: de avaliação ali na avaliação oral foi justamente algo que eu me propus a fazer baseado na nossa primeira aula né:: onde eu pedi pra que eles listassem né quais são as as:: maiores dificuldades que eles tem.

Pesquisadora: Isso ((atividade de listening como avaliação)) não é uma prática sua de outros bimestres?

Professor: Não! Isso é uma prática que eu assumo dependendo da nossa conversa no primeiro dia de aula $(+)$ entendeu? E foi algo que eu me propus a fazer com eles (+) foi um pedido deles. (SD1)

Entretanto, apesar desta crença ter gerado ações que se mostraram bastante eficientes no contexto trabalhado, é interessante notar como nenhuma das negociações tange o cerne da avaliação. Não houve um momento ao longo da primeira fase da pesquisa em que tenha sido dada voz aos alunos sobre questões como quais tipos de avaliação Ihes eram familiares, com quais instrumentos eles se sentiriam mais confiantes de serem avaliados ou quais temas Ihes permitiriam mostrar melhor a extensão do que já haviam aprendido. Além disso, também não foram apresentados aos alunos modelos alternativos de avaliação, diferentes ou complementares ao paradigma somativo com o qual estão acostumados, para que eles pudessem formular suas próprias opiniões a respeito de como melhor poderiam expressar o que sabem.

Destarte, apesar de haver o discurso de que é preciso negociar os processos avaliativos com os alunos, a prática revelou que, neste caso, embora o professor de fato negocie alguns dos processos a serem desenvolvidos em sala de aula, a avaliação ainda é um procedimento cujas decisões são tomadas unilateralmente, uma vez que as crenças do professor são as únicas levadas em consideração. 


\section{b) A prática de atividades similares às cobradas nas avaliações formais é} indispensável para o sucesso dos alunos nas mesmas. Na entrevista, o professor arguiu que a repetição é um "mecanismo de aprendizagem". Corroborando o seu discurso, ao longo de todo o bimestre, houve vários momentos nos quais o professor pediu para que os alunos realizassem exercícios similares aos cobrados tanto nos Mock Tests ${ }^{5}$ como na prova escrita. Eram exercícios de gramática, uso da língua e vocabulário, todos a respeito de tópicos presentes no livro didático no decorrer das diferentes lições.

Além dos exercícios do livro do aluno e do livro de dever de casa, também foram entregues aos alunos exercícios complementares sobre a gramática aprendida, os quais foram corrigidos na aula anterior à prova. Além disso, foi notável a preocupação do professor em preparar atividades similares às que os alunos encontrariam na prova oral. As provas orais do nível avançado deste estabelecimento de ensino são no formato $\mathrm{CAE}^{6} \mathrm{e}$, portanto, o professor mostrou, no decorrer do semestre, vídeos explicativos sobre todas as partes que compõem este modelo de prova. Além disso, ele desenvolveu apresentações de power point simulando provas de CAE para que os alunos pudessem praticar nas aulas. O professor apresentou ainda diversas maneiras de responder eficazmente às questões apresentadas na prova oral de acordo com o registro de língua pedido. Pronúncia, vocabulário, gramática e uso da língua foram trabalhados visando o bom desempenho do aluno nas provas oral e escrita. Na aula do dia 28/02, o professor explicou:

[3] Falando sobre mudanças (+) vocês se lembram que eu falei que algumas coisas mudaram para nós em termos de avaliação? OK aamm Vocês se lembram que as nossas aulas mudaram do $5 \mathrm{~A}$ para o avançado 1? Sim? Hoje nós falaremos um pouquinho sobre a nossa prova oral, e::: como eu havia falado antes, as provas orais são desenhadas de acordo com exames internacionais. Certo? E a nossa prova oral tem quatro partes distintas. Eu não vou falar sobre todas as partes, porque na próxima aula eu vou mostrá-las várias vezes,

\footnotetext{
${ }^{5}$ Mock Tests são simulações de testes. Na escola observada os Mock Tests foram trabalhados no formato de provas escritas curtas que deveriam ser aplicadas ao longo do semestre e contabilizadas na média final dos alunos. No primeiro bimestre foram utilizados cinco Mock Tests, alguns com conteúdos ministrados em sala de aula e outros com tópicos aleatórios.

${ }^{6}$ As provas orais no formato CAE (Certificate in Advanced English) possuem quatro partes: entrevista, comparação e contraste de figuras, resolução conjunta de um problema apresentado e considerações finais.
} 
ok? Porque é muita informação nova para entender e é melhor ver uma parte por vez. Então, eu só vou falar ((hoje)) sobre a primeira parte. (OA. Tradução minha)

Em seguida, o professor explicou sobre o funcionamento da prova e passou um vídeo explicativo de Cambridge à respeito da primeira parte deste formato de avaliação oral. Houve ainda vários outros momentos, em muitas outras aulas onde o mesmo tipo de explicação se fez presente novamente.

$\mathrm{Na}$ sessão de visionamento o professor reiterou o que havia informado na sua narrativa escrita, explicando que aprendeu inglês através de muito treino e repetição e que, por isso, acredita que muitos alunos podem aprender assim também. $O$ excerto abaixo, retirado da narrativa entregue pelo professor, confirma o uso destas estratégias.

[4] Em 1994, assisti à cerimônia do Oscar pela primeira vez e fiquei simplesmente obcecado em decodificar tudo o que estava sendo dito. Assistia à mesma fita repetidas vezes e acabei memorizado muitas partes da cerimônia. Não havia o recurso da tecla SAP, então a tradução simultânea clareava o significado das sentenças. (NE)

Este posicionamento reitera os trabalhos de Kalaja (1995), uma vez que a autora afirma que os professores costumam repetir em sua prática docente a maneira pela qual aprenderam ou foram ensinados. Ainda na sessão de visionamento, o professor afirmou que "na avaliação somativa o treino é necessário". Esta colocação confere um caráter coerente à prática do professor, haja vista que o mesmo entende que sua prática avaliativa é de cunho somativo e, portanto, busca estratégias que estejam de acordo com sua prática.

c) Atividades avaliativas pontuais são capazes de garantir uma mensuração satisfatória da aprendizagem dos alunos. Esta crença está implícita no comportamento do participante ao longo do primeiro bimestre. No 
primeiro dia de aula observado, o professor explicou quais seriam as atividades consideradas para a nota dos alunos, as quais são descritas na figura abaixo:

FIGURA 02: ATIVIDADES AVALIATIVAS DO PRIMEIRO BIMESTRE

\begin{tabular}{|r|l|}
\hline \multicolumn{2}{|c|}{ Nota Oral } \\
\hline Prova Oral & 80 pontos \\
\hline Apresentação Oral & 10 pontos \\
\hline Atividade de Listening & 10 pontos \\
\hline Total & 100 pontos \\
\hline
\end{tabular}

\begin{tabular}{|r|l|}
\hline \multicolumn{2}{|c|}{ Nota Escrita } \\
\hline Prova Escrita & 70 pontos \\
\hline Redação & 20 pontos \\
\hline Mock Tests (Média) & 10 pontos \\
\hline Total & 100 pontos \\
\hline
\end{tabular}

\section{Total Bimestral: Nota Oral + Nota Escrita / 2}

(Figura minha)

Através do quadro acima e após constatar que este foi exatamente o modelo de avaliação utilizado pelo professor no primeiro bimestre, é possível inferir que ele acredita que atos avaliativos pontuais são suficientes para mensurar a aprendizagem dos alunos. Ratificando suas ações, na aula do dia 25 de abril o professor reiterou o modelo de avaliação apresentado acima, lembrando aos alunos que eles precisam estar cientes de como suas notas serão divididas. Além disso, na primeira sessão de visionamento, quando apresentado à esta crença, o professor argumentou que as avaliações desenvolvidas por ele no primeiro bimestre "mostravam o quanto os alunos haviam aprendido até então".

Entretanto, contrariando a fala e a prática do professor ao longo do primeiro bimestre de aulas observadas, durante a seção de discussão do dia 28/04/2015, o professor informou que se identificou com o texto de Fidalgo (2006), explicando que:

[5] Eu sempre tive esse:: esse:: é (+) essa:: esse questionamento se realmente a avaliação ela é algo é::: um fator de medida muito preciso né $(+)$ é::.: primeiro pela minha experiência como aluno, 
porque eu notava assim que às vezes tinha matérias que eu estudava muito pouco e conseguia e::: assim, a avaliação não era muito condizente com aquilo que eu realmente sabia. (SD1)

Essa colocação vai contra o agir do professor em sala de aula, bem como algumas de suas colocações, uma vez que, como exposto acima, ele se utiliza exatamente de avaliações pontuais para medir ou classificar os alunos através de notas. Essa situação vai ao encontro das ideias de Woods (2003, p.207. Tradução minha), segundo o qual "[...] o que dizemos que acreditamos pode nem sempre ser o fator que influencia nossas ações, e pessoas podem realizar ações que parecem ser inconsistentes com o que dizem ser suas crenças".

Entretanto, além da inconsistência entre a fala e a prática do professor nesta questão, faz-se necessário considerar que, quando utilizada isoladamente, a avaliação somativa não permite que o professor observe a curva de crescimento do aluno, uma vez que congela a nota em uma atividade pontual, não possibilitando ao aluno desfrutar, também através das notas, do crescimento que obteve ao longo do período de estudo.

Em outras palavras, a utilização exclusiva de meios somativos na avaliação ocasiona a estagnação de notas parciais que não necessariamente correspondem ao real aprendizado do aluno, mas que serão somadas e divididas, como no exemplo explicitado no Quadro 1, para mensurar exatamente esta aprendizagem.

\section{d) As provas orais devem conter situações de uso real da língua. Ao} dialogar a respeito do formato da prova oral e suas partes, o professor relatou aos alunos que, na sua opinião "as provas orais deveriam conter situações de uso real da língua" e que a prova de CAE tinha essa característica.

Além disso, todas as atividades desenvolvidas pelo professor para simular a prática da prova oral também continham situações de uso real da língua, como uma entrevista de emprego e uma discussão a respeito de um tema polêmico. 
No dia $25 / 04$, ao explicar sobre os procedimentos da prova oral para os alunos, o professor reafirmou que:

[6] [...] e:: mhm sobre a interação (+) porque a primeira parte é a entrevista, a segunda parte é a descrição de uma figura e na terceira parte vocês tem que interagir juntos, lembram-se? Mhm a única coisa que eu tenho que te dizer para lembrar é:: novamente (+) como nós estamos tentando retratar uma situação real da vida, todos tem que ter voz $[\ldots](\mathrm{OA} 1)$

e) "A avaliação oral é extremamente subjetiva". Esta frase foi extraída da fala do professor na primeira sessão de discussão. Ao refletir a respeito de sua própria prática o professor exprimiu que "avaliar sempre é muito difícil e avaliar o desempenho oral dos alunos é ainda mais complicado. É sempre muito subjetivo". Quando questionado a respeito não apenas da prova oral, mas também de quais critérios utiliza para avaliar as apresentações orais, o professor respondeu que "não há critérios pré-estabelecidos:: é o que você traz e o que a gente pode refinar depois".

Em seguida, sobre as notas das apresentações orais ele afirmou que "a quantificação é bem holística mesmo", expressando que considera desde o esforço no preparo até o desempenho do aluno.

Entendo a fala do professor ao advogar que a avaliação oral é subjetiva, mas acredito que esta subjetividade pode ser minimizada com a utilização de critérios claros e objetivos. Assim, utilizo-me das palavras de Gatti (2013, p.101), quando a autora delibera que

Há sempre um certo grau de subjetividade que atua no processo e isto nem sempre é objeto de reflexão por parte do professor [...] Fica evidente que uma grande variedade de formas de avaliação é usada, em que pese a aparente uniformidade nas atribuições de notas. Evidencia-se nas pesquisas, pelas falas dos docentes, que, para cada um deles, seus próprios procedimentos são considerados, em geral, os melhores e mais justos para determinar as notas dos alunos. Mas as aproximações a que procedem, as considerações que usam para alterar padrões fixos, etc. precisariam merecer uma análise constante por parte dos professores. Não se trata de eliminar esse grau de julgamento, mas torná-lo mais explícito e analisável constantemente. 
Entretanto, o que se observa tanto na fala como no proceder do participante desta pesquisa, ao longo do primeiro bimestre de aula observado, é a total predominância da subjetividade no que se refere à avaliação oral, uma vez que não há a utilização de parâmetros ou critérios específicos para constatar a aprendizagem do aluno, ou atribuir-lhe uma nota específica.

Passo a seguir para a apresentação das crenças do segundo bloco de categorias.

\subsubsection{Como o professor acredita que os alunos concebem a avaliação}

Nesta subseção, observo não apenas como o professor percebe a visão dos alunos sobre a avaliação, mas também como estas crenças se refletem no seu proceder docente. As crenças levantadas nesta categoria foram:

a) Os alunos preferem a avaliação somativa. Este pensamento se explicitou na fala do professor na primeira sessão de discussão, ocorrida no dia 28/04/2015, pois ele afirmou que:

[7] a desconstrução disso ((do processo de avaliação somativa)) de uma forma total e completa, ela nunca (+) ela nunca é incólume (.) e essa construção $(+)$ né:: de avaliação somativa ela é algo (+) que os alunos querem mhm eles pedem [...] (SD1)

Foi possível constatar a forte influência desta crença nas ações do professor em sala de aula, haja vista que ao longo do primeiro bimestre, todas as atividades avaliativas possuíam cunho somativo, uma vez que se tratavam de atividades pontuais, às quais eram atribuídas notas que, por sua vez, eram somadas para se obter a média bimestral. $O$ reflexo do progresso dos alunos não necessariamente se refletia nestas notas e médias, uma vez que as mesmas eram parciais e estáticas. 
Como já expresso anteriormente, no que concerne o desempenho oral, os alunos foram avaliados através de uma prova oral ${ }^{7}$, uma apresentação oral e uma atividade de listening, as quais somadas valiam 100 pontos. No tocante ao desempenho escrito, os alunos foram avaliados através de uma prova escrita, uma redação e uma sequência de cinco Mock Tests, que somados valeram 100 pontos.

A situação descrita acima corrobora os estudos de Johnson (1992), segundo o qual as crenças podem influenciar direta ou indiretamente nas atitudes e ações dos professores em seu proceder docente. É interessante ainda ressaltar que 0 professor participante desta pesquisa se mostra consciente a respeito da sua própria crença ao explicitá-la, o que me leva a crer que suas tomadas de decisão, no que tange a este aspecto da avaliação, são informadas, principalmente quando me apoio em uma outra fala do professor, extraída também da primeira sessão de discussão, quando discursando a respeito de sua própria forma de avaliar: "minha primeira reação é essa (+) divide e soma".

Ainda na primeira sessão de discussão, quando questionado sobre os motivos que 0 fazem crer que os alunos preferem a avaliação somativa, 0 professor explicou que esta é a forma com a qual eles estão acostumados e, portanto, "eles pedem este tipo de avaliação". Diante desta colocação, perguntei ao professor se os alunos realmente preferem este tipo de avaliação ou se simplesmente não conheciam nenhuma outra e, consequentemente, não têm parâmetro para comparar e decidir qual tipo de avaliação realmente preferem. O professor concordou com a minha colocação e se mostrou aberto para conhecer outros modelos e instrumentos avaliativos, os quais foram apresentados durante a primeira sessão de visionamento.

\section{b) A bonificação através de pontuação é um dos maiores fatores} motivacionais para os alunos. Essa crença foi inferida, inicialmente, a partir

\footnotetext{
7 As provas orais, assim como as escritas, desta instituição de ensino são padronizadas, formuladas pela coordenação e enviadas aos professores que ministram o nível já com a pontuação pré-estabelecida. No caso do nível avançado, as provas orais seguem o formato CAE.
} 
das colocações feitas a respeito dos Mock Tests. Na aula do dia 21 de fevereiro de 2015, ao se pronunciar a respeito da necessidade de fazer estes testes, o professor ressaltou que os alunos precisariam fazê-los porque "eles são importantes para a nota". Além disso, ele combinou com os alunos que, dos cinco Mock Tests que eles fariam, ele utilizaria a nota apenas dos três melhores, ou seja, se os alunos fizessem todos os Mock Tests, poderiam ter melhores notas, já que as duas notas menores não seriam consideradas para a pontuação final. Ainda no dia 21 de fevereiro, o professor explicou que os alunos que fizessem os cinco Mock Tests propostos teriam a média das três maiores notas arredondada para cima, se fosse o caso, mas aqueles que deixassem de fazer qualquer um dos Mock Tests não teriam nenhum tipo de bonificação no arredondamento, pois a média seria fechada sem a variável após a vírgula.

Esta crença vai ao encontro da crença anterior, pois, uma vez que, segundo o professor, os alunos preferem a avaliação somativa, na qual a aprendizagem está focada no produto, que, por sua vez, é mensurado através da pontuação final, tudo o que for relacionado a pontos funcionará como fator incentivador, pois motivará os alunos a conquistar maiores pontuações.

Também quando discursando sobre as demais atividades avaliativas redação, apresentação oral e atividade de listening -, o professor sempre se preocupou em explicitar que as mesmas seriam computadas para a pontuação final dos alunos e, portanto, deveriam ser realizadas. Acredito que estas atitudes expressam a crença do professor de que o simples fato de "valer nota" já torna a atividade intrinsicamente motivacional.

Esta crença corrobora os estudos de Mesquita (2008), segundo o qual o que se observa hoje em dia é que a nota funciona tanto como fator motivacional como fator punitivo. Entretanto, o impasse do raciocínio apresentado acima, quando utilizado isoladamente, encontra-se no fato dele não observar que a pontuação deveria ser apenas a consequência de um processo bem estruturado na aprendizagem do aluno. $O$ aprender em si, e não os pontos a serem recebidos pela tarefa, deveria ser o grande fator motivacional utilizado pelos professores para incentivar os seus alunos. 


\section{c) Quanto menos critérios são impostos nas avaliações formais, mais} confiantes os alunos se sentem. Esta crença se traduziu em atitudes adotadas ao longo do bimestre e pode ter sua origem na dificuldade de comunicação enfrentada pelo professor no início do seu processo de aprendizagem, conforme expressa 0 excerto abaixo, retirado da narrativa escrita:

[8] Minha jornada como aluno e professor de inglês começou quando eu era ainda muito pequeno, com o diagnóstico leve de gagueira e dislexia. Uma amiga dos meus pais, que morou conosco durante sua graduação em pedagogia, notou que eu precisava de um acompanhamento, mas a mentalidade da época ainda era preconceituosa com relação a terapias e meus pais não eram diferentes. A qualquer sinal de ansiedade, stress ou situação atípica, que demandasse um esforço verbal de minha parte, era frustrada a ponto de eu não conseguir fazer com que as pessoas sequer entendessem o meu nome de forma clara. (NE)

Por ter enfrentado grandes dificuldades no início de sua aprendizagem, é possível que o professor tenha transferido os seus medos para os alunos, acreditando, assim, que quanto menos Ihes fossem formalmente imposto e exigido, menos estressados e ansiosos eles se sentiriam e, consequentemente, mais confortáveis estariam para se expressar.

Alguns atos me possibilitaram observar essa crença nas ações do professor em sala de aula. Primeiramente, ao solicitar a redação aos alunos, o professor aclarou apenas a data de entrega, o valor máximo que a mesma poderia atingir e o tema. Havia um modelo a ser seguido no livro didático e o professor informou a página do mesmo aos alunos. Não foi explicitado quais seriam os critérios avaliados nem os elementos que os alunos deveriam utilizar no texto.

$\mathrm{Na}$ primeira sessão de visionamento ocorrida no dia 08/05/2015, o professor relatou que costuma dar uma oficina de redação antes de pedir para que os alunos escrevam uma. Porém, como ele havia ficado ausente por duas aulas devido a um acidente pessoal, não teve como realizar a oficina. Ainda na 
sessão de visionamento o professor relatou que "escrever é um processo (+) é uma questão de talento sim (.) mas o treino realmente te ensina". Entretanto, mesmo diante da constatação da importância da oficina de redação, e a falta de tempo para realizá-la, a redação foi cobrada no primeiro bimestre sem mais critérios e integrou a nota dos alunos.

Ainda no tocante à redação, durante a sessão de visionamento 0 professor exprimiu que "você escreve por um propósito e não para ter nota". Porém, em nenhum momento das aulas este pensamento foi explicitado ou encorajado para os alunos, uma vez que tudo o que foi proposto foi que fizessem uma redação que constituiria $20 \%$ da sua nota escrita.

No que tange a apresentação oral, no dia 21 de fevereiro de 2015 o professor pediu para que os alunos fizessem uma pesquisa a respeito das raízes de sua família e que a trouxessem na aula seguinte. Mais uma vez não foram estabelecidos os critérios de avaliação e, neste caso, nem o modelo segundo o qual os alunos seriam cobrados. A informalidade do pedido fez com que os alunos compreendessem a atividade como uma tarefa muito simples, sem grandes expectativas, e não como uma apresentação formal que seria, inclusive, computada para a nota final. Além disso, a falta de clareza sobre os propósitos da atividade obscureceu a sua utilidade e os ganhos linguísticos e culturais que os alunos poderiam desenvolver através da tarefa.

Como nas duas próximas aulas o professor esteve ausente, devido ao seu acidente, quando retornou e questionou sobre a pesquisa, agora conferindo a ela o título de apresentação oral, os alunos ficaram confusos, como expresso no trecho transcrito abaixo:

[9] Professor: Eu não sei se vocês se lembram, mas a última aula que tivemos juntos $(+)$ antes do meu acidente $(+)$ eu pedi para que vocês fizessem uma apresentação oral.

Aluna A: Sim.

Aluna B: Não é uma "apresentação oral". É só uma:::

Professor: Sim, mas eu pedi para que vocês fizessem alguma pesquisa (+) sobre o quê?

Aluno B: Uma pesquisa sobre família

Professor: Sua árvore genealógica. (OA1) 
Depois de explicar que os alunos fariam suas apresentações orais em uma aula extra, no sábado precedente à prova, em função das duas aulas nas quais ele havia sido substituído, o professor afirmou que, caso alguém faltasse essa aula, não teria nenhum problema. Então uma aluna questionou:

[10] Aluna C: Então a apresentação oral não vai valer nota?

Professor: Vai sim (+) vai sim (+) Mas se vocês não vierem ((à aula extra)) eu não posso punir vocês. Vocês me entendem? Então, vocês terão que fazê-la depois.

Aluna C: Então se a gente não vier, como faremos?

Professor: Sobre a sua apresentação?

Aluna C: Sim.

Professor: Na primeira aula, depois da prova.

[...]

Aluna D: Professor, o que é nossa apresentação oral?

Professor: Apresentação Oral? O que é uma apresentação oral?

Aluna D: Não, eu sei o que é (+) mas:: é sobre nossa família, né?

Professor: É sobre sua árvore genealógica $\mathrm{mhm}$ tipo:: as origens da sua família, do seu nome [...]

Aluna D: Mas é só uma conversa, né?

Professor: É!

Aluna B: Não em frente, em pé?

Professor: Essa era a ideia, mas se vocês não quiserem levantar, vocês podem ficar sentados (+) sem problemas.

Aluno E: Quanto tempo?

Professor: Cinco minutos no má:::ximo. (OA1)

Os excertos acima demonstram a confusão dos alunos não apenas acerca dos procedimentos a serem adotados durante a apresentação, mas também a total falta de ciência dos critérios a serem utilizados na avaliação da mesma. Devido a sua ausência nas duas aulas anteriores, o professor permitiu que todos apresentassem a pesquisa na aula extra, conforme combinado, sem nenhum prejuízo de nota para os que ainda não haviam nem começado a pesquisa. Entretanto, durante a primeira sessão de visionamento, o professor assegurou que "se eu tivesse vindo na aula seguinte, eu teria punido sim (+) todos fizeram e você não!", referindo-se aos alunos que não haviam desenvolvido a pesquisa.

Esta crença do professor se traduziu em ações que não foram eficazes neste contexto de ensino, uma vez que não apenas confundiram os alunos em relação ao que e como as atividades deveriam ser realizadas, mas também não os prepararam para as tarefas exigidas, ocasionando a apresentação de 
trabalhos muito aquém do esperado, conforme confirmado pelo próprio professor durante a primeira sessão de visionamento. Esta situação evidencia que a falta de critérios e objetivos claros dificulta o entendimento do porquê e 0 para que as atividades e tarefas estão sendo desempenhadas, o que pode ocasionar o proceder mecânico dos alunos nas mesmas e não favorecer o processo de aprendizagem.

d) Os alunos têm medo de avaliações formais. Ao longo de todo o primeiro bimestre de aulas foi possível observar falas e atitudes do professor que enfatizam esta crença. $\mathrm{Na}$ aula do dia 21 de fevereiro de 2015, quando questionado sobre o que seriam os Mock Tests, o professor explicou que:

[11] [...]quando alguém diz Mock Test as pessoas pensam que Mock Test/ o significado de Mock Test é somente um teste surpresa punitivo e cruel (+) ok (+) mas um Mock Test é uma simulação de um teste de verdade [...] então um Mock Test é um teste simulador. (OA1)

No dia 25 de abril, ele voltou a afirmar que os alunos acreditam que Mock Test são muito difíceis. Na primeira sessão de visionamento, ele afirmou ainda que os "alunos não têm muito respaldo para fazer um Mock Test e às vezes precisam de um professor terapeuta", se referindo ao fato de muitos alunos sempre questionarem e reclamarem com o professor a respeito da dificuldade e do medo que tem deste tipo de teste.

Esta crença se reflete não apenas na forma como o professor lida com as atividades avaliativas formais, conforme exposto através da crença 'c' desta subseção, mas também em todo o discurso expresso em sala de aula, com o qual ele sempre tenta tranquilizar os alunos sobre as avaliações, informando que os Mock Tests são "apenas simulações", que as apresentações orais são "apenas conversas" e que as provas orais não passam de "situações reais de uso da língua", com as quais "eles já estão acostumados". 
Além disso, acredito que todo o cuidado que o professor tem em 'treinar' os alunos para os testes, como expresso na subseção anterior, também se constitui em uma estratégia para alimentar a confiança dos alunos, visando ocasionar mais segurança nos momentos de avaliação.

Após apresentar e discutir sobre todas as crenças levantadas, apresento a síntese das mesmas no quadro abaixo.

\section{QUADRO 5 - SÍNTESE DAS CRENÇAS}

\section{CATEGORIA}

1. Como o professor

percebe suas próprias

práticas avaliativas, os

instrumentos avaliadores

e a avaliação em si.

\section{Como o professor}

acredita que os alunos

concebem a avaliação.

\section{CRENÇAS}

- É importante negociar os processos avaliativos com os alunos.

- A prática de atividades similares às cobradas nas avaliações formais é indispensável para o sucesso dos alunos nas mesmas.

- Atividades avaliativas pontuais são capazes de garantir uma mensuração satisfatória da aprendizagem dos alunos.

- As provas orais devem conter situações reais de uso da língua.

- A avaliação oral é extremamente subjetiva.

- A avaliação somativa é algo que os alunos querem.

- A bonificação através de pontuação é um dos maiores fatores motivacionais para os alunos.

- Quanto menos critérios são impostos nas avaliações formais, mais confiantes os alunos se sentem.

- Os alunos têm medo de avaliações formais.

(Quadro meu)

Assim, uma vez respondida à primeira pergunta de pesquisa, através da explicitação de quais são as crenças do professor participante da pesquisa e de que forma essas crenças se relacionam às tomadas de decisões do professor em sala de aula, discorro, na próxima seção, a respeito do processo e dos indícios de ressignificação de algumas crenças. 


\subsection{PROCESSO DE RESSIGNIFICAÇÃO DE CRENÇAS}

Nesta seção, analiso primeiramente os fatos ocorridos nas sessões de discussão e visionamento, faço o levantamento de todas as mudanças no tocante à avaliação propostas ao professor participante, descrevo brevemente os processos avaliativos adotados por ele no segundo bimestre e, por fim, teço comentários sobre discursos e atitudes que se constituem em indícios de ressignificação de crenças, apresentados pelo professor ao longo do segundo bimestre de 2015 e na última sessão de visionamento.

\subsubsection{Processos de Reflexão}

O modelo de ressignificação de crenças adotado neste estudo é o de Arruda (2008, p.33), conforme elucidado no capítulo de embasamento teórico. Assim, foi necessário não apenas levar o professor a conhecer métodos alternativos de avaliação, mas também possibilitar momentos de reflexões prospectivas e retrospectivas, visando propiciar ao professor a oportunidade de se contemplar enquanto docente, bem como de visualizar novos caminhos e posturas.

Para tanto, fiz uso de sessões de discussão e visionamento, sobre as quais discorro a seguir.

\subsubsection{Primeira Sessão de Discussão}

O primeiro passo proposto neste estudo para se iniciar o processo de ressignificação de crenças foi o estabelecimento de momentos que possibilitassem ao professor a reflexão sobre suas próprias práticas. Assim, a leitura dos textos sobre avaliação se fez basilar para os propósitos desta pesquisa, uma vez que por intermédio deles o professor pode ponderar, primeiramente sozinho e depois junto à pesquisadora, sobre os caminhos que a avaliação trilhou até o presente momento, e a maneira pela qual ela vem sendo trabalhada efetivamente em diversos contextos. 
Além disso, os textos também se ocupavam em argumentar sobre a necessidade de se repensar a avaliação através de bases formativas, que possibilitassem ao professor trabalhar com todas as nuances da avaliação, primordialmente com o seu caráter diagnóstico e processual. Dessa forma, através de reflexões retrospectivas à luz das ideias apresentadas no texto, 0 professor pode enxergar a sua própria prática na voz de pesquisas e pesquisadores, fazer uma auto avaliação e passar para reflexões prospectivas, ponderando sobre as possibilidades de inovação na sua prática, ou a permanência das que já desenvolve.

Nesta sessão, ocorrida no final do primeiro bimestre de aulas de 2015, o professor teve liberdade para expor todas as suas considerações a respeito dos textos lidos, com pouca ou nenhuma interferência da pesquisadora. Assim, ele ratificou muitas de suas crenças, mas também contradisse, através do seu discurso, algumas de suas práticas, como já exposto na seção anterior. Além disso, certas considerações do professor nesta sessão procederam diretamente da reflexão ocasionada pelos textos, como ilustra o excerto a seguir.

[12] ((o texto fala)) sobre essa:: essa:: essa necessidade de diálogo, entre o que:: o que realmente se ensina, o quanto realmente se ensina e o quanto realmente se aprende e essas é:: variáveis formas de:: de:: de aprendizado que perpassam a avaliação e que ela não é somente uma / um termômetro de medida né (+) ela também é uma oportunidade de aprendizado. (SD1)

Além disso, o professor também concordou com o texto de Fidalgo (2006), no que diz respeito à necessidade de mudanças no modelo de avaliação vigente, mas da implausibilidade de se pensar que uma construção cultural de avaliação estruturada ao longo de séculos será desconstruída rapidamente. A seguinte fala expressa este pensamento do professor: "[...]então, na verdade, as mudanças elas tem que ser feitas né:: é::: a contagotas, mas você não consegue mudar tudo de uma vez só (+) então eu achei isso muito lúcido". 
Além disso, o professor conseguiu se identificar em diversas falas dos textos, expressando que:

[13] [...] pra todo tipo de:: de:: de perfil de professor que ele põe aqui, eu acho que eu sou todos eles ou já fui muitos, né, eu acho que sou todos eles porque eu acho que é uma postura né:: o que eu sou hoje é um resultado das minhas posturas no passado até chegar aqui... então eu me enxerguei em quase tudo o que ele falou aqui né:: então tem o professor carrasco, eu acho que eu já fui um professor extremamente carrasco [...] ((hoje)) eu me acho menos ((carrasco)) [...] mas é muito difícil você se colocar nessa posição assim, né:: de:: de se enxergar. (SD1)

Outra questão levantada pelo professor na sessão de discussão foi a importância de momentos de reflexão como este:

[14] E eu acho que é só:: só por meio disso aqui ((leitura e reflexão)), saca, você sai do lugar comum você ouvir né:: assim outras opiniões, ver outros professores em ação é::::: passar por experiências de aprendizado às vezes assim extremamente distintas [...] faz com que você né reveja e acrescente né:: $\mathrm{mhm}$ na verdade não é $\mathrm{mhm}$ a questão não é só rever é você toda hora acrescentar um elemento a mais do que é aprender. (SD1)

Ainda sobre as finalidades desta pesquisa, o professor afirmou que achava extremamente importante o "treinamento consciente de como a avaliação deve ser feita para que todos falem a mesma língua". Assim, exatamente através de momentos reflexivos e de adaptação ao contexto de cada sala de aula seria possível estruturar a avaliação das escolas de formas eficazes, processuais e diagnósticas.

No final desta seção, a pesquisadora esclareceu o propósito da pesquisa, os fundamentos teóricos que a guiam e questionou como o professor se enxergava, após a leitura dos textos, como professor avaliador, além de perguntar ainda como a avaliação que ele exerce consegue ajudar o seu aluno em sala de aula a crescer e melhorar. O professor respondeu que as leituras o haviam levado a perceber que sua forma de avaliar não era nem diagnóstica 
nem formativa e, portanto, ele estava disposto a conhecer e tentar implementar formas alternativas de avaliação na sua prática docente.

Por fim, a pesquisadora começou a discursar sobre uma proposta de avaliação diferenciada para o segundo bimestre, a qual foi amplamente explicitada na sessão de visionamento, conforme relatado na seção seguinte.

\subsubsection{Primeira Sessão de Visionamento}

Alguns dias depois da sessão de discussão, desenvolvemos a sessão de visionamento, na qual o professor pode assistir e analisar a sua própria prática pedagógica no que tange à avaliação, além de fazer considerações sobre ela. Ao discursar sobre as imagens selecionadas, o professor ratificou e explicou diversas de suas crenças, como exposto nas seções anteriores. Entretanto, ao se deparar com algumas situações, ele se mostrou surpreso ao observar o seu proceder. Tal fato se deu principalmente no tocante:

1) ao discurso repetitivo de não punição, pois ao assistir sua prática o professor percebeu que em diversas aulas ele enfatiza que não irá punir os alunos através de notas. A este respeito ele relatou: "eu falo muito sobre penalidades e isso me incomoda bastante:: e eu vou me policiar para o futuro".

2) à falta de critérios na avaliação das apresentações orais. Ao ver os trechos selecionados o professor pode observar que a falta de critérios pré-estabelecidos para a avaliação destas apresentações não apenas deixou os alunos confusos como não permitiu aos alunos expressarem tudo o que poderiam caso o comando da atividade tivesse sido claro. Quanto a este ponto, o professor afirmou que sempre acreditou que os alunos prefeririam um ambiente informal, sem muitas especificações na hora das apresentações, mas que através dos vídeos assistidos havia percebido que, pelo menos neste contexto, sua estratégia não havia sido efetiva. 
Em dado momento da sessão de visionamento o professor brincou afirmando que "se eu não tivesse me escutado falando isso ali eu ia dizer que você tava mentindo". Portanto, acredito que a sessão de discussão foi fundamental para que ele conseguisse enxergar a sua prática de uma forma mais holística, observando inclusive o que nem ele mesmo acreditava que estava fazendo.

Assim, esta sessão foi crucial para que o participante da pesquisa se sentisse ainda mais interessado em conhecer e analisar outras práticas avaliativas, sobre as quais discorro a seguir.

\subsubsection{Propostas de mudança}

Após um momento de intensas reflexões, ainda na primeira sessão de visionamento, propus ao professor algumas alterações no estilo de avaliação que o mesmo adotou no primeiro bimestre de aulas. Todas as estratégias apresentadas ao professor foram ponderadas previamente com base no calendário de aulas do segundo bimestre da instituição de ensino, levando-se em consideração o nível dos alunos, a quantidade de aulas restantes e o volume de conteúdo a ser ministrado antes do término do semestre, além da literatura vigente sobre avaliação no ensino de LE.

Assim, percebendo que uma das questões apontadas pelo professor em diversos momentos de discussão foi a questão da subjetividade da avaliação, criei uma tabela de critérios para a avaliação de apresentações orais e uma tabela com critérios para avaliação de redações, as quais exponho abaixo. $O$ objetivo de ambas seria trazer mais clareza e objetividade tanto para 0 enunciado da atividade quanto para a correção e avaliação da mesma, pois, uma vez pautada em critérios claros e bem estabelecidos, a atividade, seja ela oral ou escrita, poderia ajudar o aluno a entender melhor o que fazer e, posteriormente no que melhorar. No tocante ao professor, este poderia, de fato, fazer da avaliação em si um momento diagnóstico ao entregar para os alunos 
as tabelas de correção e ajudá-los a visualizar os pontos mais fracos a serem trabalhados.

Antes de discursar sobre os textos e modelos que inspiraram a elaboração das grades de critérios apresentadas neste estudo, é importante ressaltar que as tabelas desenvolvida nesta pesquisa se propuseram a suprir uma necessidade real e imediata de um cenário específico, no caso, a sala de aula de uma turma de avançado 1 do professor participante deste estuo. Assim, as tabelas aqui desenvolvidas não se constituem em um modelo fixo e imutável, mas pelo contrário, resume-se em um modelo passível de adaptações de acordo com as necessidades da turma, do nível, do professor envolvido e de diversos outros fatores que envolvem o processo de ensinar e aprender uma LE.

Formulamos a primeira tabela, intitulada "Critérios para avaliação de Apresentações Orais", a partir da leitura de trabalhos acadêmicos que abordam a importância e a necessidade da existência de critérios no momento de se avaliar o aluno oralmente, tais como: "Avaliação da proficiência oral em inglês como língua estrangeira: foco na competência lexical e uma proposta para o processo de validação do descritor "vocabulário" de um teste de proficiência para professores de língua inglesa" (BONVINO, 2010), "Avaliação de Proficiência Oral em Língua Estrangeira: descrição dos níveis de candidatos falantes de espanhol no exame Celp-Bras" (SHHOFFEN, 2003) e os demais textos que abordam o assunto e constam na bibliografia deste trabalho. Além disso, os descritores utilizados nos testes de proficiências TOEFL, TEPOLI, TOEIC, CAE e CPE também foram levados em consideração na construção da tabela.

Assim, com o intuito de apresentar ao professor uma grade de critérios modelo, o seguinte quadro foi desenvolvido: 


\section{QUADRO 6 - CRITÉRIOS PARA AVALIAÇÃO DE APRESENTAÇÕES ORAIS}

\section{Critérios para avaliação de Apresentações Orais}

\section{Aspectos Meritórios}

\section{Pontuação}

\begin{tabular}{|c|c|c|c|}
\hline Pronúncia & 0 & 0.5 & 1.0 \\
\hline Fluência & 0 & 0.5 & 1.0 \\
\hline Vocabulário & 0 & 0.5 & 1.0 \\
\hline Estruturas Gramaticais: concordância; regência; colocação verbal e nominal & 0 & 0.5 & 1.0 \\
\hline Explicitação dos Objetivos do Trabalho e Adequação ao Tema Proposto & 0 & 0.5 & 1.0 \\
\hline Coesão e Coerência: sequência lógica de ideias e sólida articulação de fatos ou argumentos & 0 & 0.5 & 1.0 \\
\hline Utilização de itens gramaticais e lexicais aprendidos durante o semestre & 0 & 0.5 & 1.0 \\
\hline Cumprimento e Dimensionamento do Tempo Designado à Apresentação & 0 & 0.5 & 1.0 \\
\hline Postura Diante do Tema Abordado e dos Companheiros Presentes & 0 & 0.5 & 1.0 \\
\hline Estrutura e Organização Geral da Apresentação: preparação e recursos & 0 & 0.5 & 1.0 \\
\hline Aspectos Demeritórios & \multicolumn{3}{|c|}{ Pontuação } \\
\hline Interferência da Língua Materna (Tradução Literal) & 0 & -0.5 & -1.0 \\
\hline Repetição exaustiva de palavras ou expressões & 0 & -0.5 & -1.0 \\
\hline
\end{tabular}

(Quadro meu)

No tocante à segunda tabela, elaborada por nós e intitulada "Critérios para avaliação de redações", foi inspirada em modelos brasileiros, como os critérios utilizados para a correção de provas do ENEN, e internacionais, como os descritores do IELTS. Assim, tento ainda considerado os anseios do professor participante da pesquisa no primeiro bimestre de aulas observadas, bem como as colocações feitas por ele a respeito dos propósitos das redações que solicitava aos seus alunos, apresentei a ele o quadro que se segue, novamente com o intuito de expor um modelo que ele poderia adaptar de acordo com as necessidades e peculiaridades que se apresentassem em sala de aula. 


\section{QUADRO 7 - CRITÉRIOS PARA AVALIAÇÃO DE REDAÇÕES}

Critérios para avaliação de Redações

Aspectos Meritórios
Pontuação

\begin{tabular}{|l|l|l|l|}
\hline Ortografia & 0 & 1.0 & 2.0 \\
\hline Coesão e Coerência: sequência lógica de ideias e sólida articulação de fatos ou argumentos & 0 & 1.0 & 2.0 \\
\hline Estruturas Gramaticais: concordância; regência; colocação verbal e nominal; pontuação & 0 & 1.0 & 2.0 \\
\hline Domínio da Norma Culta da Língua Escrita & 0 & 1.0 & 2.0 \\
\hline Utilização de itens gramaticais e lexicais aprendidos durante o semestre & 0 & 1.0 & 2.0 \\
\hline \multicolumn{1}{|c|}{ Aspectos Demeritórios } & \multicolumn{2}{|c|}{ Pontuação } \\
\hline Fuga de Tema & 0 & -0.5 & -1.0 \\
\hline Interferência da Língua Materna (Tradução Literal) & 0 & -0.5 & -1.0 \\
\hline Repetição exaustiva de palavras ou expressões & 0 & -0.5 & -1.0 \\
\hline \multicolumn{1}{|c|}{ Pontuação Final da Redação: } & & \\
\hline
\end{tabular}

(Quadro meu)

Com base em todas as leituras que realizei, pude perceber que a dificuldade em avaliar está presente em todas as esferas da educação e que através da utilização de critérios claros e bem estabelecidos o professor não apenas limita o grau de subjetividade aplicado à avaliação, mas também consegue precisar para o aluno de forma mais assertiva quais são os aspectos que necessitam de mais atenção.

O planejamento avaliativo bimestral não foi novidade para o professor, pois ele já planejava a avaliação e definia os instrumentos avaliativos bimestralmente antes do início da pesquisa, como observado no primeiro bimestre. Entretanto, a proposta que realizei previa uma mudança no estilo de avaliação e, consequentemente, também na forma que os instrumentos eram utilizados e pontuados. Haja vista que na escola em questão o professor era responsável por planejar apenas por $20 \%$ das notas das avaliações oral e escrita, pois os outros pontos eram destinados às provas enviadas pela coordenação, foi exatamente dentro destes 20 pontos que propus as mudanças. 
No que concerne à avaliação escrita, havendo a impossibilidade de propor um plano de portfólio completo, uma vez que não haveria tempo para a realização de muitas redações devido ao volume de conteúdo a ser ministrado no segundo bimestre, perguntei ao professor se seria possível realizar duas redações que comporiam os $20 \%$ da nota escrita, e propus que as mesmas seguissem a correção classificatória de Serafini (2001), na qual o professor marca o erro através de uma classificação pré-definida, oferecendo assim a oportunidade do aluno se auto corrigir. Este fato, segundo Sarafini (ibidem), permite que a ideia original do texto seja mantida pelo aluno na nova versão. Além disso, como o professor não dá a correção para o aluno, é este quem precisa se empenhar para não apenas entender o erro, como também tentar enxergar as possíveis formas de corrigi-lo, dividindo assim a responsabilidade do processo de ensino/aprendizagem com o seu professor.

Os símbolos a serem utilizados pelo professor na correção das redações seguiriam o modelo da tabela já utilizada na escola, conforme quadro abaixo, e deveriam ser explicados aos alunos, para que todos se encontrassem familiarizados com os mesmos no momento da reescrita de suas redações.

\section{QUADRO 8 - CORRECTION SYMBOLS}

\begin{tabular}{|c|c|c|c|}
\hline Symbol & Explanation & Example & Correction \\
\hline WW & wrong word & She isn't married, she is singerww. & She isn't married, she is single. \\
\hline WWF & wrong word form & $\begin{array}{l}\text { Dan is my better }{ }^{W W F} \text { friend. } \\
\text { Larry is AmericaWWF. } \\
\text { You don't speak clear }\end{array}$ & $\begin{array}{l}\text { Dan is my best friend. } \\
\text { Larry is American. } \\
\text { You don't speak clearly. }\end{array}$ \\
\hline WVT & wrong verb tense & I'm watching ${ }^{W V T}$ TV everyday. & I watch TV everyday. \\
\hline WVF & wrong verb form & He like ${ }^{W V F}$ dancing. & He likes dancing. \\
\hline WO & word order & I have a car new ${ }^{\text {WO}}$. & I have a new car. \\
\hline WP & wrong preposition & It depends of $\mathrm{WP}$ the situation. & It depends on the situation \\
\hline PI & Portuguese interference & I have 10 years. ${ }^{P I}$ & I am 10 years old. \\
\hline Cap & Capitalization error & I speak english ${ }^{\text {Cap }}$ & I speak English. \\
\hline sp & spelling error & He's a teetcher ${ }^{\text {sp }}$. & He's a teacher. \\
\hline $\begin{array}{l}\mathrm{PL} \\
\text { sing }\end{array}$ & plural / singular & $\begin{array}{l}\text { I have a new pant }{ }^{P L} \text {. } \\
\text { She bought a houses }\end{array}$ & $\begin{array}{l}\text { I have new pants. } \\
\text { She bought a house }\end{array}$ \\
\hline 1 & Separate & I work alot. & I work a lot \\
\hline $\bar{F}$ & Omit & We have a good news. & We have good news \\
\hline$\Lambda$ & insert a word & I am student. & I am a student. \\
\hline $\mathbf{P}$ & punctuation mistake & However ${ }^{P}$ I did not know him. & However, I did not know him. \\
\hline $\begin{array}{l}{[\ldots]} \\
\text { frag. }\end{array}$ & check whole fragment & $\begin{array}{l}\text { [Despite I live here I wanted } \\
\text { move.] }{ }^{\text {frag }}\end{array}$ & $\begin{array}{l}\text { Although I like living here I want } \\
\text { to move. }\end{array}$ \\
\hline
\end{tabular}

(Fonte: Cooperativa de Idiomas) 
A figura abaixo ilustra o processo proposta na correção das redações através da utilização de símbolos e reescrita:

\section{FIGURA 03 - REDAÇÕES}

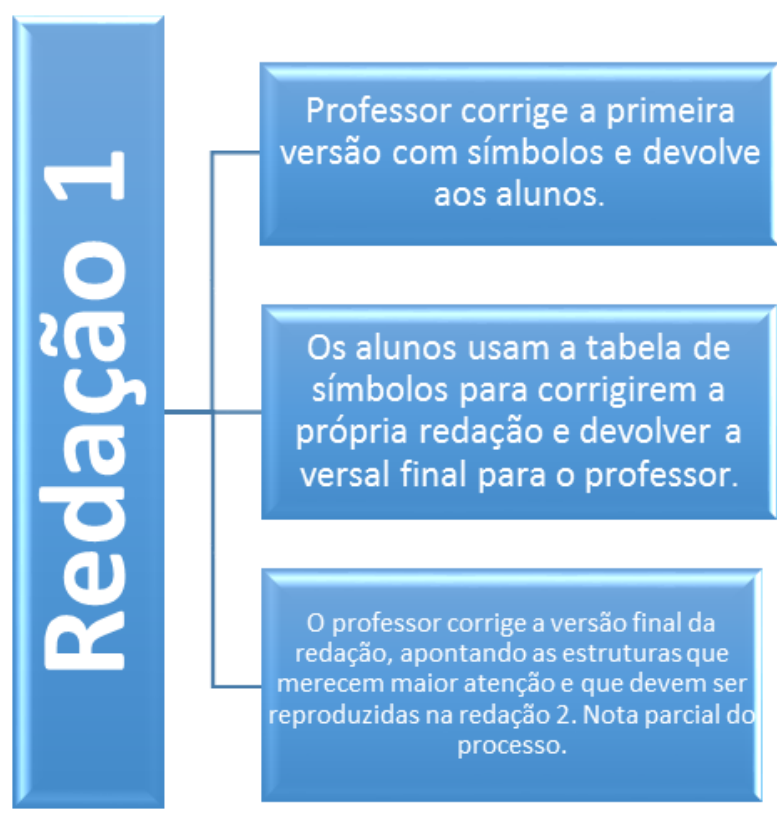

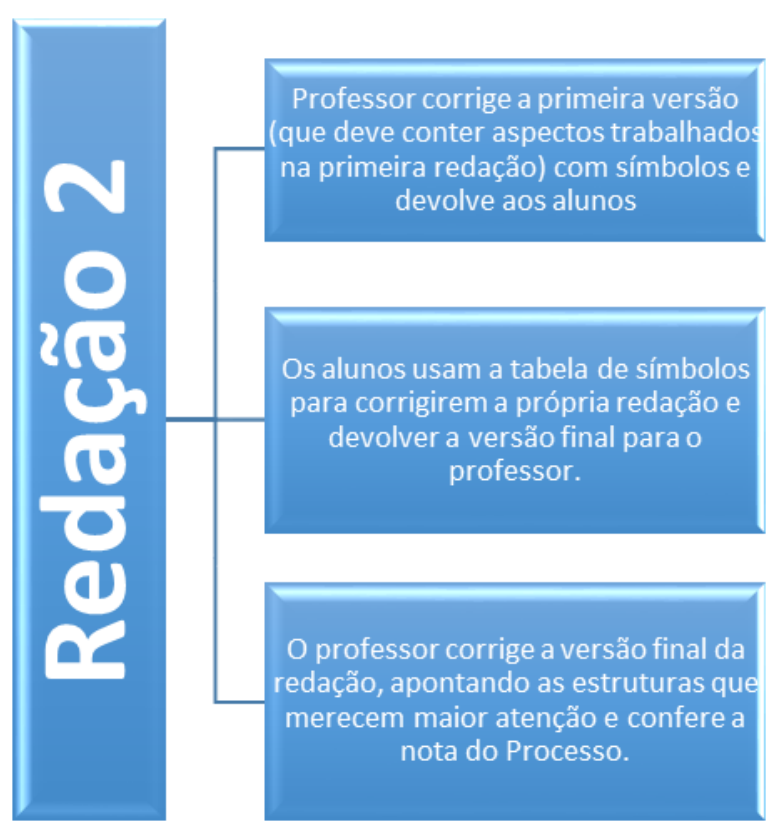

(Figura minha)

O primeiro fato importante a ser notado na proposta acima é o fato de que a Redação 1 não recebe uma nota final, mas sim uma nota parcial que será substituída pela nota final do processo. A importância de se atribuir uma nota parcial encontra-se no fato de que alguns alunos podem não realizar a segunda redação e, portanto, contarão apenas com a nota da primeira.

Ambas as redações seriam pontuadas de acordo com os critérios estabelecidos na tabela de "Critérios para Avaliação de Redação" já exibida neste estudo. Entretanto, na Redação 2, o aluno deveria utilizar as estruturas que teve maior dificuldade na redação anterior. Dessa forma, ele poderia treinar o uso apropriado de estruturas gramaticais ou vocabulares aprendidas, visando a internalização das mesmas. A nota final do aluno seria a nota da versão final da Redação 2, uma vez que seria exatamente nesta última que ele conseguiria mostrar o que de fato aprendeu e consegue produzir. 
De forma semelhante se daria a produção oral. Propus que o professor realizasse duas apresentações orais, as quais seriam avaliadas de acordo com critérios de avaliação pré-estabelecidos e dos quais os alunos estivessem cientes. O feedback da primeira apresentação deveria ser passado para os alunos antes da segunda apresentação, preferencialmente logo após a apresentação da mesma, uma vez que o aluno teria a oportunidade de observar o que errou e se corrigir para a segunda apresentação. Os critérios de pontuação seguiriam a tabela de "Critérios para Avaliação Oral", sendo a nota da segunda apresentação a nota final do aluno, uma vez que ele teria tido a oportunidade de treinar na primeira, se auto corrigir e melhorar para a segunda.

Nesta proposta, tanto na apresentação oral quanto nas redações, os alunos deveriam ser informados dos critérios de avaliação no momento em que a atividade fosse solicitada, bem como providos com detalhes do que se espera da mesma, preferencialmente através de um modelo.

Diante deste tipo de procedimento, seria possível calcular a curva de crescimento do aluno, não para fins de nota, mas para que alunos e professor pudessem averiguar todos os pontos de crescimento e aqueles que ainda precisariam de maiores atenções.

Além disso, diferentemente da prática adotada no primeiro bimestre, a utilização de critérios pré-estabelecidos possibilitaria aos alunos entender exatamente o que seria avaliado e, portanto, eles saberiam como se preparar para apresentações e redações, além de, após a realização das mesmas, poderem visualizar exatamente os aspectos nos quais obtiveram maiores ou menores desenvolturas. No tocante ao professor, os critérios poderiam facilitar a aferição de conhecimento e, consequentemente de notas, além de conferir clareza e objetividade à pontuação.

Acredito que através deste tipo de avaliação, o professor não apenas proporcionaria momentos altamente diagnósticos, mas também evitaria congelar notas ou menções durante o processo, sem que o aluno tivesse a oportunidade de crescer e mostrar o que aprendeu. Além disso, esta prática concede visibilidade ao processo, uma vez que, o aluno tem todo o espaço 
alocado de tempo dentro do bimestre/semestre, de acordo com os prazos discutidos com o professor, para se aprimorar no que está sendo ensinado.

Informei ao professor, ainda, o fator motivacional deste tipo de avaliação, o qual só seria alcançado com sucesso se os alunos entendessem o real propósito da mesma. Expliquei que, uma vez ciente do seu papel diante deste estilo de avaliação, o aluno teria a consciência de que the é dada a oportunidade de melhorar constantemente durante o processo, caso ele realmente se disponha a tanto. Enfatizei ainda que a avaliação formativa permite que o professor realmente divida a responsabilidade da avaliação com os alunos, haja vista que estes podem ou não desenvolver todas as tarefas propostas ao longo do semestre - no caso, bimestre - e podem ou não buscar sempre melhorar de uma atividade para a outra. Dessa forma, é o aluno quem toma para si a responsabilidade de crescer, não podendo, como é comumente observado nas escolas, jogar a responsabilidade somente para o professor.

Além disso, o fato de não ter se saído bem em uma dada atividade, ou de ter perdido alguma avaliação não interferirá dramaticamente na nota do aluno, uma vez que entendemos que também não necessariamente interfere no seu processo de aprendizagem. Dependendo do volume de atividades solicitadas, aquela perdida pode ser refeita, caso assim o aluno e o professor desejem, ou as habilidades a serem demonstradas nela podem simplesmente serem observadas na próxima atividade semelhante, uma vez que o objetivo seria ajudar o aluno a caminhar sempre ascendentemente durante o processo de aprendizagem.

Diante de todas as minhas colocações, o professor participante aceitou utilizar as tabelas de critérios para redação e apresentação oral. A redação proposta por ele foi um texto analítico sobre um livro da escolha dos alunos, o qual deveria também ser o conteúdo da apresentação oral. Neste momento, eu o informei que as tabelas não tinham a necessidade de serem fixas, uma vez que cada turma apresenta a sua realidade específica. Assim, ele poderia ter a liberdade de fazer qualquer modificação que julgasse necessária para melhor atender os propósitos avaliativos daquele grupo. Destarte, apresento abaixo os quadros com as modificações criadas pelo professor. 


\section{QUADRO 9 - CRITÉRIOS PARA CORREÇÃO DA REDAÇÃO: ANÁLISE ESCRITA DO LIVRO}

\begin{tabular}{|l|c|c|c|}
\hline \multicolumn{1}{|c|}{ Aspectos Positivos (12 pontos) } & \multicolumn{2}{c|}{ Pontuação } \\
\hline Coerência e Coesão: sequência lógica de ideias e sólida argumentação & 0 & 1.0 & 2.0 \\
\hline Estruturas Gramaticais: concordância; colocação (verbal, nominal, adjetivos e preposições) & 0 & 1.0 & 2.0 \\
\hline Parágrafos: os conteúdos são divididos apropriadamente (como solicitado) & 0 & 1.0 & 2.0 \\
\hline Tamanho: a quantidade de palavras é apropriada para o nível (como solicitado) & 0 & 1.0 & 2.0 \\
\hline Vocabulário: colocação, variedade, apropriação e utilização precisa do vocabulário avançado & 0 & 1.0 & 2.0 \\
\hline Registro: o grau de formalidade correto é mantido ao longo da redação & 0 & 1.0 & 2.0 \\
\hline \multicolumn{1}{|c|}{ Realização da Tarefa (8 points) } & \multicolumn{2}{c|}{ Pontuação } \\
\hline Legibilidade e impressão apropriada do paper, em tinta (como solicitado) & 0 & 0.25 & 0.5 \\
\hline Uso de pelo menos uma sentença com estrutura de inversão & 0 & 0.5 & 1.0 \\
\hline Uso correto de pontuação: maísculas, parênteses, aspas e sentenças. & 0 & 0.5 & 1.0 \\
\hline A história é contada no presente simples & 0 & 0.5 & 1.0 \\
\hline A história é satisfatoriamente esboçada, sem muitos detalhes. & 0 & 0.5 & 1.0 \\
\hline Não há spoilers (ou pelo menos existem alertas de spoiler) & 0 & 0.25 & 0.5 \\
\hline Há um equilíbrio entre os pontos positivos e os negativos do livro & 0 & 0.5 & 1.0 \\
\hline Usou adjetivos para descrever o livro (página 41) & 0 & 0.5 & 1.0 \\
\hline A recomendação (seja para ler ou não o livro) está clara & 0 & 0.5 & 1.0 \\
\hline \multicolumn{1}{|c|}{ Aspectos Negativos } & Pontuação \\
\hline Fuga ao tema & 0 & -5.0 & -10 \\
\hline Interferência do português obscurece a mensagem ou torna as estruturas muito básicas & 0 & -2.5 & -5.0 \\
\hline A mensagem não está clara & 0 & -2.5 & -5.0 \\
\hline O texto foi plagiado de outra fonte & 0 & -10 & -20 \\
\hline Comentários: & & \\
\hline \multicolumn{1}{|c|}{ Pontuação Final: } & & \\
\hline
\end{tabular}

(Fonte: Professor participante da pesquisa. Tradução minha)

\section{QUADRO 10 - AVALIAÇÃO (APRESENTAÇõES ORAIS)}

\begin{tabular}{|c|c|c|c|}
\hline Aspectos Positivos (7 pontos) & \multicolumn{3}{|c|}{ Pontuação } \\
\hline Boa pronúncia & 0 & 0.5 & 1.0 \\
\hline Boa fluência & 0 & 0.5 & 1.0 \\
\hline Estruturas Gramaticais: concordância; colocação (verbal, nominal, adjetivos e preposições) & 0 & 0.5 & 1.0 \\
\hline Coerência e Coesão: sequência lógica de ideias & 0 & 0.5 & 1.0 \\
\hline Gestão do Tempo: uso equilibrado do tempo designado para a apresentação & 0 & 0.5 & 1.0 \\
\hline Resources used: clear signs of preparation and good delivery of the subject matter & 0 & 0.5 & 1.0 \\
\hline Reasonable attempt to use the vocabulary that has been dealt with in previous lessons & 0 & 0.5 & 1.0 \\
\hline Realização da Tarefa (3 points) & \multicolumn{3}{|c|}{ Pontuação } \\
\hline Discursou sobre as razões pelas quais ela/ele escolheu o livro & 0 & 0.25 & 0.5 \\
\hline Descreveu a história do livro bem (sem spoilers) & 0 & 0.25 & 0.5 \\
\hline Mencionou o que ela/ele aprendeu com o livro & 0 & 0.25 & 0.5 \\
\hline Discursou sobre as razões pelas quais ela/ele recomenda ou não o livro & 0 & 0.25 & 0.5 \\
\hline Mencionou o autor e trouxe informações interessantes sobre ela/ele & 0 & 0.25 & 0.5 \\
\hline Impacto global da apresentação: realização com êxito da tarefa & 0 & 0.25 & 0.5 \\
\hline Aspectos Negativos & \multicolumn{3}{|c|}{ Pontuação } \\
\hline Fuga ao tema & 0 & -5.0 & -10 \\
\hline Interferência da Língua Materna (Tradução Literal) & 0 & -0.5 & -1.0 \\
\hline A mensagem não está clara. & 0 & -0.5 & -1.0 \\
\hline Comentários: & & & \\
\hline Pontuação Final: & & & \\
\hline
\end{tabular}

(Fonte: Professor participante da psquisa. Tradução minha) 
No que tange às atividades avaliativas propostas, 0 professor argumentou que ele não acreditava que seria possível proceder com a realização de duas redações e duas apresentações orais, haja vista a quantidade de aulas restantes e o volume de conteúdo a ser ministrado. Ele explicou que poderíamos pensar em uma outra forma de observar a curva de crescimento dos alunos, uma vez que havia se interessado pela ideia. Assim, apenas uma redação e uma apresentação oral foram desenvolvidas no segundo bimestre de aulas observadas. Após avaliarmos algumas opções para observar a curva de crescimento dos alunos, decidimos observá-la em relação às atividades desenvolvidas no primeiro bimestre. Assim, foi possível inclusive perceber o efeito da introdução dos critérios no mesmo tipo de avaliação. Dessa forma, a redação do segundo bimestre foi comparada à redação do primeiro bimestre e o mesmo se deu com as apresentações orais. O professor decidiu, então, que a nota previamente dedicada à atividade de listening daria espaço para a nota da curva de crescimento do aluno. A figura abaixo ilustra 0 processo desenvolvido no segundo bimestre:

FIGURA 04 - AVALIAÇÃO DO SEGUNDO BIMESTRE

\begin{tabular}{|r|l|}
\hline \multicolumn{2}{|c|}{ Nota Oral } \\
\hline Prova Oral & 80 pontos \\
\hline Apresentação Oral & 10 pontos \\
\hline Curva de Progressão & 10 pontos \\
\hline Total & 100 pontos \\
\hline
\end{tabular}

\begin{tabular}{|l|l|}
\hline \multicolumn{2}{|c|}{ Nota Escrita } \\
\hline Prova Escrita & 70 pontos \\
\hline Redação & 20 pontos \\
\hline Mock Tests (Média) & 10 pontos \\
\hline Total & 100 pontos \\
\hline
\end{tabular}

\section{Total Bimestral: Nota Oral + Nota Escrita / 2}

(Figura Minha)

Outro ponto a ser citado no que diz respeito às mudanças ocorridas no segundo bimestre foi o fato de o professor ter desenvolvido a oficina de redação com os alunos, o que gerou ainda maior clareza em relação aos componentes necessários à redação solicitada. 


\subsubsection{Indícios de Ressignificação}

Quando o assunto é ressignificação de crenças, concordo com Barcelos (2007) e Arruda (2008), pois as autoras enfatizam que as crenças não são ressignificadas de forma simples e linear. Pelo contrário, são momentos de rupturas e acomodações, com muitas idas e vindas que permitem ao professor não apenas testar as novas ideias, mas também melhorá-las, e, então, caso constatada a sua eficiência e validade dentro de um dado contexto, permitir que a mesma faça parte da sua prática docente, até que uma próxima ideia apareça para ser novamente testada, validada ou refutada.

Embasada nas afirmativas acima, entendo não ser possível constatar a ressignificação de crenças do professor participante da pesquisa apenas através da observação do segundo bimestre de aulas e da segunda sessão de visionamento e segunda sessão de discussão. Acredito, porém, que o professor apresentou através do seu discurso e prática alguns indícios que sinalizam o começo do processo dinâmico da ressignificação das crenças, sobre os quais discorro nesta seção.

Antes de passar aos indícios, entretanto, é necessário informar que, no final do semestre, na aula anterior às provas finais, o professor participante me concedeu um espaço para conversar com os alunos da turma, dando-Ihes a oportunidade de conhecer um pouco mais sobre a pesquisa e expressar suas opiniões sobre a mesma. Assim, nesta seção estão contidos também comentários tecidos pelos alunos neste momento inicialmente não previsto na pesquisa.

O primeiro indício de ressignificação de crenças se encontra no fato de o professor ter adotado as tabelas de critério de avaliação, uma vez que esta atitude demonstra uma preocupação do professor em gerar mais clareza e objetividade nos processos avaliativos, o que, inicialmente, não era considerado muito importante, uma vez que o professor entendia que "quanto menos critérios são impostos nas avaliações formais, mais confiantes os alunos se sentem". Na última sessão de visionamento, dia 13/07/2015, o professor pode assistir e comparar o seu proceder no primeiro e segundo 
bimestres de aula, no tocante ao uso de critérios na avaliação. Assim, ele afirmou que

[15] Acho que comparando né a primeira com a segunda é:: (+) a apresentação do que que é pra né do que é pra ser feito assim acho que toda essa preocupação é muito grande né Thalita porque:: como você tinha me falado assim fica muito mais claro o que que é pra fazer como deve ser feito né é:: quando você tem os critério né à mão (.) ali no caso da segunda ((segundo bimestre)) é:: eu passei no power point ((os critérios)) eu realmente não dei isso escrito pra eles, embora eu tenha pedido pra que eles tirassem né foto dos slides pra que eles tivessem isso em mente quando eles tivessem fazendo a pesquisa né e se preparando para a apresentação. Eu noto que:: assim pensando na primeira é mais ou menos um reflexo do que que do que que eu como aluno às vezes é:: acharia:: [...] (SV2)

A fala acima indica que o professor reconhece que o uso dos critérios deixa o processo mais claro, facilitando o preparo dos alunos para as tarefas propostas. Além disso, é possível perceber no excerto acima o fato de o professor entender que uma das crenças que ele imputava como sendo dos alunos é, na verdade, uma crença dele e que, neste caso, a mesma não se traduzia em uma prática eficaz.

A percepção da importância dos critérios também influenciou a crença do professor de que "a avaliação oral é extremamente subjetiva". Após utilizar os critérios para as avaliações orais, o professor informou a pesquisadora que, apesar das avaliações orais ainda possuírem um caráter subjetivo, ele havia percebido que esta subjetividade havia diminuído significativamente devido ao estabelecimento de critérios claros e objetivos.

Ademais, outro fator que reforça este indício é o fato de que o professor não apenas utilizou as tabelas da forma que lhe foram entregues, mas teve o cuidado de adaptá-las para os propósitos do nível. Ele incorporou elementos que tiveram grande impacto na turma, como a sessão de comentários. Ainda no tocante aos critérios, o professor teve a oportunidade de escutar a satisfação dos alunos diante dos mesmos, conforme demonstrado nos excertos abaixo, extraídos da aula do dia 20/06/2015, o que corroborou as suas percepções iniciais sobre a introdução dos critérios. 
[16] Aluno A: Com relação realmente ao feedback é eu sempre tive muita dificuldade com o inglês [...] a gente fica muito perdido sem saber o que tá errando (.) eu sei que minha pronúncia não é muito boa, mas:: em que aspectos ela não é boa em que pontos ela realmente tem falha entendeu? [...] eu nunca tive feedback e o fato de tipo assim do:: a falta de correção sempre me gerou um desinteresse muito grande [...] eu consegui recuperar a motivação que nem no começo eu acho que eu tava e acho que a grande parte foi realmente relacionada a estes feedbacks.

Aluna A: Eu acho que ((a tabela de critérios)) dá transparência e perde um pouco da subjetividade da avaliação. (OA2)

Entretanto, é importante esclarecer que o professor explicitou em diversos momentos a dificuldade em utilizar as tabelas, principalmente no quesito que ele mesmo incorporou: os comentários. Para tecer considerações sobre cada um dos alunos, o professor precisou dedicar muito mais do seu tempo, o que pode vir a constituir um fator impeditivo caso o professor se encontre, em semestres vindouros, ministrando aulas para muitas turmas.

O segundo indício de ressignificação de crenças se encontra no fato de o professor não apenas ter adotado a ideia de mostrar aos alunos as suas curvas de crescimento ao longo do semestre, mas criar uma nota específica para esta curva, ideia que partiu do próprio professor. Apesar de não ter sido a ideia original proposta, acredito que o simples fato de o professor querer introduzir uma nota que evidencia o processo demonstra o entendimento da importância do mesmo e do fato de que uma avaliação formativa pode funcionar como fator motivacional para os alunos.

Após escutar os comentários dos alunos sobre a avaliação proposta no segundo bimestre de aulas, o professor teve a oportunidade de perceber que a avaliação em si pode se constituir em um fator motivacional para os mesmos, a partir do momento que ela se centra no processo de aprendizagem dos alunos, cria momentos diagnósticos, é pautada em critérios claros e possui como uma de suas bases o dividir de responsabilidades entre professores e alunos. Esse entendimento informa uma abertura para um pensamento que vai além da crença inicial do professor de que "a bonificação através de pontuação é um dos maiores fatores motivacionais para os alunos". 
Sobre o processo de avaliação formativa, os alunos comentaram:

[17] Aluna B: Em relação à curva também é MUITO BOM porque às vezes você até sabe fazer aquele dever mas naquele momento você fica um pouco aéreo e você depois a sua nota fica ali congelada sendo que você depois pode melhorar e assim e recuperar o que você perdeu naquele momento às vezes você sabe [...] achei essa sua ideia de progressão e de curva muito boa (.) nos motiva também em pensar ah eu posso estudar mais $(+)$ posso melhorar $(+)$ ela $((a$ curva)) motiva.

Aluna C: Pena que ela ((avaliação formativa)) já chegou só no meio [...] porque a gente poderia ter feito mais redações, mais atividades pra ver essa curva melhor. (OA2)

Outro ponto que pode indicar o processo de ressignificação foi discutido na última sessão de visionamento. Ao assistir ao vídeo da aula na qual os alunos conversaram com a pesquisadora a respeito da pesquisa, perguntei ao professor se, diante de todas as colocações dos alunos ele continuava acreditando que eles preferiam a avaliação somativa, haja vista que os alunos se surpreenderam com a apresentação do modelo formativo e da possibilidade de poderem visualizar graficamente a sua curva de crescimento. A resposta do professor se encontra no trecho transcrito abaixo

[18] Professor: Eu acho que sim e não. Eu ainda acho que $\left.{ }^{(*}\right)$ se a gente implodisse todas as bases né de tudo aquilo que eles construíram e pensam né em relação à avaliação e falar olha aqui vai ser tudo diferente, aqui não vai ter nenhuma avaliação somativa eu eu eu ainda acho que alguns deles poderiam assim alguns poderiam falar assim tipo "será que isso é sério?" né:: eu acho que essa mescla, eu acho que a gente ((da escola onde ele trabalha)) faz isso bem no sentido de que a gente tem o momento da avaliação somativa mas a gente tem a liberdade de:: escolher outros momentos de avaliação e aí você pode é é fazer com que né sejam outros momentos mesmo e incluir e contemplar este tipo de avaliação ((formativa)) porque eu acho que se você só fizer de uma forma (+) só somativa ou:: é:: só progressivo o aluno [...] eu acho que eles não (.) não é que eles não dão crédito mas eu acho que eles poderiam questionar a seriedade "será que isso é uma escola séria?" (SV2)

Depois desta fala, a pesquisadora perguntou ao professor se, uma vez cientes da existência da avaliação formativa, os alunos realmente prefeririam a 
avaliação somativa, ou se esta preferência se dá exatamente pelo fato deles não terem acesso a formas alternativas de avaliação, uma vez que o que conhecem por avaliação geralmente é a mesma forma pela qual os seus professores foram avaliados, ou seja, através do divide e soma. O professor então afirmou que não havia pensado nisto antes e que, de fato, pode ser que os alunos prefiram a avaliação somativa porque não tiveram acesso a um outro tipo de avaliação.

Após ter respondido à segunda pergunta de pesquisa, explicando como momentos guiados de reflexão, através da intervenção embasada na literatura corrente sobre avaliação, podem contribuir de forma significativa para o processo de ressignificação de crenças, discorro a seguir sobre como o professor participante desta pesquisa reagiu aos resultados do estudo, mesmo depois de não estar mais sendo observado, ocasionando mais indícios de que crenças estão sendo ressignificadas.

\subsection{O IMPACTO}

Após o término do desenho inicial da pesquisa, pude constatar que a mesma não se findaria nas observações de aula, nas sessões reflexivas ou na escrita desta dissertação. Através do contato contínuo com o professor participante deste estudo, uma vez que trabalhamos na mesma instituição de ensino, conforme explicitado no capítulo metodológico, pude observar que a inquietação iniciada na primeira sessão de discussão não apenas permanece acesa como talvez esteja ainda mais intensa do que durante o corpo da pesquisa.

Apresento a seguir as evidências que me levaram a crer no expresso acima. 


\subsubsection{Orientação sobre avaliação para os novos professores}

Uma vez findado o semestre letivo e haver o professor participado da última sessão de visionamento, o mesmo propôs um desdobramento que, ao meu ver, constitui-se não apenas no maior indício de que crenças realmente estão em processo de ressignificação, mas também em uma das grandes contribuições deste estudo.

Como já explicitado no perfil do professor participante da pesquisa, o mesmo encontra-se na posição de assistente da diretoria pedagógica do estabelecimento de ensino que abrigou esta pesquisa. Assim, uma das suas funções como assistente pedagógico é conduzir as oficinas de orientação dos novos professores da instituição. Ao término da última sessão de visionamento, o professor me informou que havia percebido a necessidade de se abrir espaços para discussões sobre avaliação e, consequentemente, estava criando um novo módulo de orientação cujo tema seria Avaliação.

Assim, no dia 14/08/2015, desenvolveu-se a primeira orientação sobre avaliação desta instituição de ensino, contando com o professor participante da pesquisa, um coordenador administrativo, uma coordenadora pedagógica, quatorze novos professores e eu, na qualidade de pesquisadora, podendo contribuir com muito do que foi apresentado nesta pesquisa. Todos tiveram a oportunidade de se pronunciar e aprender sobre o assunto, ocasionando um momento de reflexões intensas e valiosas trocas de experiências. Através da fala dos novos professores, o professor participante deste estudo teve suas impressões sobre a avaliação formativa reforçadas. Além disso, ele pode perceber o quão necessário o momento se fez, uma vez que alguns dos professores não sabiam conceitos básicos sobre avaliação e, ainda assim, entrariam em sala para avaliar os seus alunos.

Acredito que esta situação demonstra um impacto profundo na forma de pensar o processo avaliativo do professor. Ele demonstrou uma preocupação que ultrapassa a sua própria sala de aula e atinge toda a cooperativa em questão. Além disso, essa abertura abre novas possibilidades dentro da escola, 
uma vez que, segundo o próprio professor, a Avaliação tornou-se parte do currículo permanente das orientações dos novos professores da instituição.

A seguir, discuto sobre a segunda sessão de discussão, a qual ocorreu devido a demanda do professor em dialogar mais a respeito de processos avaliativos.

\subsubsection{A segunda sessão de discussão}

No dia 25 de novembro de 2015 realizamos a segunda sessão de discussão, inicialmente não prevista, ocasionada pelo interesse do professor em informar sobre os caminhos que vêm seguindo após o término das observações de aulas que realizei, além da expressa vontade em dialogar e conhecer outras perspectivas no tocante à avaliação.

Nesta sessão, o professor me explicou que está trabalhando com a mesma turma que eu havia observado no semestre anterior, a qual se encontra atualmente no último nível do curso, o avançado 2. Ele me explicou que deu continuidade ao modelo de avaliação adotado na pesquisa, utilizando tabelas de critérios, tanto nas avaliações das apresentações orais como das redações, além de estabelecer um diálogo mais aberto com os alunos a respeito de com quais instrumentos avaliativos eles se sentiriam mais à vontade de serem avaliados, bem como os temas a serem abordados nas avaliações formativas. Sobre a negociação dos processos avaliativos, o professor afirmou que "((antes da pesquisa)) eu negociava mais prazo (+) prazo pra entregas e tudo mas não era:: não existia nenhuma negociação no sentido assim do do dos instrumentos de avaliação tipo assim com o que a gente vai avaliar".

Como exemplo da mudança deste tipo de atitude, o professor me explicou que, após deliberações com os alunos, foi decidido que as apresentações orais poderiam ser enviadas via o aplicativo whatsapp, mas sem leitura, a respeito de notícias que os alunos tivessem contato durante a semana e quisessem compartilhar com os seus colegas. Entretanto, é importante ressaltar que todos os critérios que seriam utilizados para a avaliação destas apresentações foram apresentados aos alunos antes da produção das 
mesmas, além do fato de o professor ter exibido um modelo feito por ele mesmo para os alunos, o qual ele me apresentou durante esta sessão de discussão.

Ainda no tocante às apresentações orais, o professor explicou que os alunos poderiam gravar várias apresentações orais e enviar no grupo de whatsapp da turma, sendo que o professor sempre daria o feedback delas, individualmente, para que o aluno pudesse desenvolver as próximas utilizandose das questões aprendidas nas primeiras. $O$ professor elucidou que a implementação das apresentações via whatsapp foi discutida com os alunos, sendo que eles mesmos apontaram as vantagens e desvantagens do processo, chegando a conclusão de que a experiência seria muito prática e proveitosa para todos.

A respeito dos temas das apresentações, eu apontei ao professor que uma outra estratégia, seguindo o mesmo raciocínio já adotado, seria trabalhar na mesma apresentação oral mais de uma vez, fazendo com que o aluno a enviasse pelo whatsapp apenas para o professor, e não para o grupo da turma, e o professor daria o feedback para que o aluno se sentisse mais confiável e pudesse trabalhar ainda mais na sua apresentação para, somente então, enviar uma versão melhorada para todo o grupo escutar. $O$ aluno poderia refazer a mesma apresentação várias vezes, o que seria um treino cada vez mais enriquecedor tanto das questões vocabulares e gramaticais quanto da pronúncia e fluência. O professor se mostrou aberto à sugestão e informou que tentaria implementá-la no segundo bimestre de aulas de 2015.

O professor me explicou ainda que a utilização de critérios durante a pesquisa e agora, no novo semestre, o havia feito perceber que a avaliação oral "é subjetiva mas pode ter critérios que deixam ela menos subjetiva", e enfatizou que o uso de critérios o fez entender que existem diversas outras possibilidades que se tornam muito mais fáceis de serem delineadas a partir do estabelecimento de diretrizes claras e pontuais. Sobre a forma que avaliava as atividades orais antes da pesquisa ele relatou 
[19] Então assim eu tinha dúvida muitas dúvidas em relação à à parte escrita é algumas na parte oral assim dúvidas do tipo que "será que eu faço essa apresentação informal?" eu realmente né tinha essa crença de que se eu não dissesse pro aluno que / eu eu falo pra ele no primeiro dia que "olha a gente vai ter apresentações orais" mas eu eu eu eu engano ele falando pra ele que não que é uma conversa informal assim como eu digo pra ele que a prova também é uma conversa informal aí ele vai fazer aquilo assim sem sem muito:: sem sem todas as pressões assim eu não quero que a pressão emocional afete a produção dele na hora que eu tô avaliando mas eu não digo pra ele que eu tô avaliando né é:: uma é é uma conversa informal pegadinha $(+)$ eu tava te avaliando $(+)$ mas isso de uma certa forma assim me incomodava mas eu vivia bem porque eu achava que estava fazendo a coisa certa eu achava que os alunos eles eram é bem sucedidos assim em linhas gerais alguns não eram justamente pela falta de critérios assim e aí eu ficava frustrado né "pô mas fulano não se empenhou então né:: a nota dele vai ser x" então se ele viesse me questionar eu falava "não a sua nota foi $x$ porque você não se empenhou aqui ou lá na sua apresentação foi assim foi assado" né e era tudo sempre muito informal (...) depois da pesquisa eu consegui identificar "cara eu faço tudo errado TUDO não tem nada certo" (risos) (...) (SD2)

No que concerne às avaliações escritas, o professor me mostrou 0 portfólio das redações que os alunos estavam desenvolvendo, também seguindo o processo sugerido no modelo inicial da pesquisa, apresentado nas seções anteriores. Ao protótipo apresentado, o professor acrescentou 0 trabalho com macro habilidades, sendo que em alguns parágrafos do texto ele trabalhou com os alunos apenas os conceitos de estruturação do parágrafo e em outros apenas a complexidade das ideias elaboradas. Ele continuou utilizando os símbolos na correção das redações e os alunos tiveram a oportunidade de reescrever seus textos, visualizando assim todo o processo e observando a sua curva de crescimento dos primeiros parágrafos escritos para a redação final. A respeito da crença apresentada originalmente por ele em relação à utilização de critérios e avaliação de redações o professor informou que

[20] Eu acho que assim antes da pesquisa é:: sempre houve a inquietação por exemplo de como a gente avalia né:: (...) aqui ((nesta instituição de ensino)) é::::: a minha dificuldade era eu sempre me incomodei com essa coisa de: não é é não ensina o aluno a escrever lê a tarefa no livro e ele escreve e aí você avalia (+) eu acho muito traiçoeiro isso sempre achei e eu tinha essa resistência a trabalhar com símbolos ((de correção de redação)) porque eu achava que muitas vezes não não não ajudava (...) e eu nunca nunca fui ensinado 
a trabalhar com os símbolos então eu tinha essa resistência de usar

$\left({ }^{* *}\right)$ por uma questão né de de como foi que eu aprendi. (SD2)

Quanto às notas, o professor explicou que estava tentando mudar a mentalidade dos alunos e a sua própria, salientando que aqueles alunos que se propusessem a participar de todas as etapas das atividades orais e escritas conseguiriam aprimorar suas habilidades e, consequentemente, atingir notas correspondentes. Entretanto, a mentalidade de um ensino pautado em avaliações somativas é arraigada no imaginário de pais e alunos o que, por sua vez, torna o processo de abrir novos caminhos e possibilidades um pouco mais árduo, mas ainda possível.

Por fim, discutimos, ainda nesta segunda sessão de discussão, conversamos a respeito da dificuldade advinda do tempo disposto no cronograma da escola e algumas ideias para minimizar a falta de tempo, como a utilização de recursos tecnológicos dentro e fora de sala de aula.

Acredito, portanto, que ambos os convites apresentados nesta seção confirmam o fato do professor participante desta pesquisa estar em um momento de intensas reflexões a respeito dos processos avaliativos, tendo saído da sua zona de conforto no tocante ao assunto a ponto de querer envolver vários outros professores na discussão e testar técnicas e modelos avaliativos diferenciados. Essa tomada de consciência se constitui, ao meu ver, no grande impacto desta pesquisa no professor participante do estudo, principalmente quando aliada à decisão de sair do lugar comum, como pode ser observado nas palavras do próprio professor ao expressar "[...] então eu achei muito bacana é o $\left(^{* *}\right)$ tudo o que você me colocou pra ler pra refletir né pra implementar e aí eu perdi muito o medo de testar e ver que não dá certo e falar: olha gente não deu certo vamos mudar".

Destarte, após ter apresentado as situações que revelam o impacto que o presente estudo produziu no professor participante, apresento, a seguir, uma síntese deste capítulo. 


\subsection{SÍNTESE}

Ao fim deste capítulo é possível constatar que várias das crenças deste professor se originaram tanto nas suas experiências anteriores de aprendizagem quanto em práticas adotadas sem muita reflexão ao longo dos anos exercendo a profissão docente. Em diversos momentos das sessões realizadas com o professor ele afirmou que nunca havia dedicado um tempo de qualidade para analisar questões relativas à avaliação.

Destarte, esta pesquisa pôde proporcionar este momento de reflexão, através do contato com a literatura vigente sobre avaliação, além de possibilitar que 0 professor visualizasse a sua própria prática e discutisse sobre ela, através das sessões de visionamento e discussão. A implementação de métodos alternativos de avaliação, voltados para uma prática formativa, com a possibilidade de momentos diagnósticos abriu uma gama de novas possibilidades para o professor, que não apenas testou os novos padrões sugeridos pela pesquisadora, mas os adaptou para a realidade e necessidade da sua turma.

Após o término das observações de aula, depois de muitas discussões sobre vários aspectos que englobam a avaliação e diante da eficácia das novas técnicas e modelo implementados, o professor não se enxergou em muitas de suas próprias palavras, extraídas da primeira sessão de discussão, quando ele ainda não havia tido a oportunidade de refletir sobre suas crenças e tomadas de decisão em sala de aula.

Consequentemente, foi possível observar, ao longo do segundo bimestre letivo de aulas observadas, bem como em sessões posteriores ao término das observações, indícios de que muitas das crenças - que se mostraram inicialmente arraigadas ao pensar e agir do professor em questão - estão cedendo espaço para novas possibilidades.

Entretanto, entendo que o processo pelo qual o professor participante desta pesquisa está passando é apenas o começo de um momento de reflexões, tentativas e, possivelmente, implementações e adaptações de novos modelos para o contexto de ensino de inglês como LE no qual ele está 
inserido. Apenas após a experimentação mais profunda das ideias propostas nesta pesquisa e, caso o professor comprove a eficácia e plausibilidade das mesmas, elas poderão vir a incorporar a sua rotina de processos avaliativos.

A figura abaixo expõe de forma sintética os indícios de ressignificação de algumas crenças, além de demonstrar também aquelas que permanecem.

\section{FIGURA 05: SÍNTESE DE INDÍCIOS DE RESSIGNIFICAÇÃO E PERMANÊNCIA DE CRENÇAS}

\section{CRENÇAS ORIGINAIS}

\section{É importante negociar os processos avaliativos com os alunos.}

A prática de atividades similares às cobradas nas avaliações formais é indispensável para o sucesso dos alunos nas mesmas.

Atividades avaliativas pontuais são capazes de garantir uma mensuração satisfatória da aprendizagem dos alunos.

As provas orais devem conter situações reais de uso da língua.

A avaliação oral é extremamente subjetiva.

\section{A avaliação somativa é algo} que os alunos querem.

A bonificação através de pontuação é um dos maiores fatores motivacionais para os alunos.

Quanto menos critérios são impostos nas avaliações formais, mais confiantes os alunos se sentem.

Os alunos têm medo de avaliações formais.

\section{APÓS AS INTERVENÇÕES}

Atualmente, o professor negocia não apenas os prazos das atividades, mas também os assuntos a serem trabalhados, bem como os instrumentos para que os mesmos sejam executados.

O profesor continua praticando atividades similares às cobradas nas avaliações formais por constatar a eficácia das mesmas.

O professor observou que através do foco no processo e elaboração de atividades diagnósticas é possível não somente ajudar os alunos de forma mais precisa mas também observar o mensurar de forma mais acertada o quanto os alunos estão conseguindo acompanhar o ensino proposto.

A mesma postura continua sendo adotada.

Através da adoção de critérios claros e objetivos, o professor percebeu que é possível minimizar o fator subjetividade na hora das avaliações orais.

Após as implementações ocorridas no segundo bimestre de 2015, uma conversa com os próprios alunos e a pesquisadora, o professor percebeu que possivelmente os alunos não conhecem outras formas de avaliação e, consequentemente, não possuem parâmetros para decidir o que de fato preferem.

Através da adoção de algumas técnicas e alternativas da avaliação formativa, o professor percebeu que o processo de aprendizagem em si pode vir a ser um grande fator motivacional para os alunos.

O professor percebeu que a adoção de critérios não apenas facilitou a realização das atividades, mas proporcionou clareza e objetividade no momento das explicações e da avaliação das mesmas.

O professor continua com a mesma posição, apesar de entender que a adoção de critérios e o treino sistemático podem gerar maior confiança quando nas avaliações formais. 
Através do quadro acima, é possível notar diversos indícios de que algumas crenças do professor estão sendo ressignificadas, além do fato de que algumas crenças permanecem. Acredito que os momentos reflexivos ocasionados por esta pesquisa possibilitaram ao professor vislumbrar uma nova realidade, instigando-o a se auto questionar com mais frequência e a querer saber sempre mais a respeito das possibilidades que cercam a avaliação de LE.

Assim, após ter analisado os dados registrados ao longo desta pesquisa e discursado sobre suas consequências na forma de pensar e agir do professor participante, bem como nas perceptíveis diferenças ocasionadas pelas intervenções propostas neste estudo, passo, a seguir, para as considerações finais desta pesquisa. 


\section{CONSIDERAÇÕES FINAIS}

Recria tua vida, sempre, sempre. Remove pedras e planta roseiras e faz doces. Recomeça.

Cora Coralina

O presente trabalho se propôs a ser um momento de pausa na rotina de um professor cujas crenças e perspectivas sobre avaliação estavam arraigadas primordialmente em conceitos somativos.

Destarte, com o intuito de proporcionar momentos reflexivos capazes de gerar uma inquietação com o lugar comum e voltar os pensamentos do professor para práticas alternativas de avaliação, desenvolvemos ao longo da pesquisa duas sessões de discussão e duas sessões de visionamento, todas voltadas para os princípios avaliativos que iluminam este estudo, utilizando como base argumentativa as observações de aulas realizadas no primeiro e segundo bimestre de 2015, à luz da literatura que embasa a avaliação formativa.

Portanto, com o objetivo de delinear as considerações finais deste estudo, tecemos a seguir cinco seções. Na primeira, retomamos os objetivos e perguntas que alicerçaram esta pesquisa, articulando sobre os desdobramentos do estudo que permitiram as respostas encontradas. Em seguida, na seção 5.2, discutimos a respeito das contribuições provenientes deste estudo, delimitando-as entre questões práticas, metodológicas e teóricas. $\mathrm{Na}$ terceira seção, discorremos a respeito dos fatores que se constituíram em limitação para esta pesquisa e as consequências dos mesmos. A seção 5.4 elenca sugestões para futuras pesquisas que podem se desenrolar a partir dos desdobramentos desta. Por fim, a última seção deste capítulo se preocupa em tecer breves ponderações a respeito de alguns assuntos que geraram intensas reflexões no decorrer da pesquisa.

Passo, portanto, às considerações sobre os objetivos e perguntas de pesquisa. 


\subsection{RETOMANDO OS OBJETIVOS E PERGUNTAS DE PESQUISA}

O intento último desta pesquisa foi entender de que forma as crenças de um professor sobre avaliação influenciavam suas tomadas de atitude em sala de aula e como, através de momentos reflexivos, seria possível iniciar o processo de ressignificação de crenças. Assim, objetivos e perguntas de pesquisa foram elaborados, visando contemplar o processo de ensinoaprendizagem a partir da perspectiva da avaliação.

O primeiro objetivo deste estudo se preocupou com "a identificação das crenças de professores de inglês concernentes à avaliação dos seus alunos, visando entender como as mesmas influenciam as ações dos professores em sala de aula". Para alcançar este objetivo, foi elaborada a seguinte pergunta de pesquisa: "Quais são as crenças do professor participante no que tange à avaliação e de que forma essas crenças se relacionam as suas tomadas de decisões em sala de aula?".

Como detalhado na capítulo analítico, o professor manifestou crenças sobre avaliação tanto no tocante a sua própria prática docente e 0 ato de avaliar em si, como na forma como enxerga as percepções dos seus alunos sobre a avaliação. Além disso, durante as observações de aula, foi possível constatar quão incisivamente estas crenças influenciavam os processos avaliativos que desenrolavam em sala de aula, fato este que corrobora os estudos de Almeida Filho (1993, vide Capítulo 2, seção 2.3).

Visando retomar a resposta da primeira pergunta de pesquisa, elaboramos o quadro abaixo, o qual exibe um compêndio das crenças do professor participante, relacionando-as com algumas atitudes tomadas em sala de aula durante o primeiro bimestre de aulas de 2015, antes das intervenções realizadas. Ademais, o quadro evidencia ainda o fato do professor apresentar crenças que não se traduziam no seu agir em sala de aula, mas existiam apenas no seu discurso. 


\section{QUADRO 11: SÍNTESE DE CRENÇAS E SUAS INFLUÊNCIAS}

\section{\begin{tabular}{|l|}
\multicolumn{3}{c}{ Como o professor pe } \\
os instrumento \\
CRENÇAS \\
\hline - É importante negociar os \\
processos avaliativos com os \\
alunos. \\
- A prática de atividades similares \\
às cobradas nas avaliações
\end{tabular} formais é indispensável para o sucesso dos alunos nas mesmas.}

- Atividades avaliativas pontuais são capazes de garantir uma mensuração satisfatória da aprendizagem dos alunos.

- As provas orais devem conter situações reais de uso da língua.

- A avaliação oral é extremamente subjetiva.

\section{CATEGORIA 1:}

rcebe suas próprias práticas avaliativas, pavaliadores e a avaliação em si.

\section{INFLUÊNCIAS NO AGIR DO PROFESSOR}

Nas aulas observadas o professor sempre discursava sobre negociar a avaliação com os alunos. Entretanto, as negociações giravam apensa em torno de prazos para entrega de trabalhos.

O professor desenvolveu diversas atividades similares as que seriam cobradas nas avaliações ao longo das aulas observadas, sempre enfatizando a necessidade do treino para o sucesso nas avaliações formais.

Durante todo o primeiro bimestre de aulas observados, os alunos foram avaliados por atividades pontuais, como provas, uma redação e uma apresentação oral. A nota final foi dada pela média aritmética destas atividades.

Tanto as provas como as apresentações orais foram desenvolvidas a partir de situações de uso real da língua.

Todas as atividades formais, inclusive as orais, foram avaliadas sem critérios claros pré-estabelecidos.

\section{CATEGORIA 2:}

Como o professor acredita que os alunos concebem a avaliação.

- A avaliação somativa é algo que os alunos querem.

- A bonificação através de pontuação é um dos maiores fatores motivacionais para os alunos.

- Quanto menos critérios são impostos nas avaliações formais, mais confiantes os alunos se sentem.

- Os alunos têm medo de avaliações formais.

Todas as atividades avaliativas desenvolvidas no primeiro bimestre de aulas de 2015 eram de cunho somativo.

O professor tentou, em diversos momentos, convencer os alunos a realizar as atividades propostas através da arguição de que, se eles assim o fizessem, teriam melhores notas ou ganhariam pontos pelas atividades.

No momento de solicitar a apresentação oral e a redação dos alunos, o professor não se preocupou em estabelecer quais seriam os critérios utilizados na avaliação das mesmas, informando basicamente o tema e o prazo de entrega das atividades.

O professor sempre tentou mostrar para os alunos que as atividades avaliativas não passavam de conversas, no caso das orais, ou de estruturar no papel o que eles já sabiam (no caso da escrita). Além disso, a falta de imposição de critérios, segundo o professor, favoreceria um cenário mais confortável para os alunos, que não se sentiriam tão pressionados no momento de desempenhar as atividades avaliativas propostas.

(Quadro meu) 
O quadro acima nos permite perceber que sim, o professor carregava diversas crenças relacionadas à avaliação e que essas crenças afetavam diretamente o seu proceder em sala de aula, seja na preparação das atividades avaliativas, na forma de apresentá-las aos alunos ou em como as notas eram atribuídas.

O segundo objetivo deste estudo visava "observar de que forma momentos de reflexão poderiam abrir portas para novas perspectivas e para a ressignificação de crenças concernentes à avaliação". Para tanto, a seguinte pergunta de pesquisa foi criada: "Como momentos guiados de reflexão podem contribuir para a ressignificação de crenças?"

Através da introdução da primeira sessão de discussão e da primeira sessão de visionamento, a pesquisadora ofereceu ao professor a oportunidade não apenas de conhecer modelos e técnicas alternativas de avaliação, através da literatura vigente, mas também propiciou ao professor a possibilidade de analisar a sua própria prática, através das gravações das suas aulas, e discutila à luz de conceitos formativos.

Estes momentos reflexivos permitiram que o professor se abrisse para novas ideias e passasse, no segundo bimestre de 2015, a implementar novas ideias avaliativas na sua prática docente. Acredito, portanto, que este despertar de consciência para novas perspectivas, aliado ao testar do novo paradigma, permitiram que o professor, durante a segunda sessão de visionamento, comparasse os parâmetros utilizados no primeiro bimestre com aqueles implementados no segundo para, então, começar a estabelecer uma nova rede de ideias que podem vir a moldar uma nova realidade de avaliação para este professor. Os resultados aqui encontrados vão ao encontro das ideias de Arruda (2008), as quais, conforme amplamente elucidado no capítulo de fundamentação teórica, alocam a reflexão no centro dos processos de melhoramento da prática pedagógica.

Por conseguinte, foi possível observar, ainda que brevemente, como momentos guiados de reflexão, pautados nas experiências de outros que se propuseram a escrever sobre o assunto e elaborar assim a literatura que embasa este trabalho, não apenas fizeram com que o professor vislumbrasse 
novas alternativas avaliativas, mas que se mostrasse disposto a testá-las e, posteriormente, permitir que as velhas crenças começassem a ceder lugar ao conhecimento advindo de reflexões, testes, aceitações, refutações e novas certezas.

Por fim, o último objetivo deste estudo se importava em "observar o impacto desta pesquisa sobre o professor participante e suas práticas no que concerne a avaliação". Para alcançar este objetivo, desenvolvemos a terceira pergunta de pesquisa: "Qual impacto esta pesquisa teve sobre as crenças e práticas do professor participante?"

A necessidade deste objetivo se encontra no entendimento de que as crenças nem sempre se refletem nas ações dos professores, podendo existir apenas no discurso, conforme elucidado por Borg (2003) no capítulo de fundamentação teórica. Diante desta colocação, fez-se necessário observar se o impacto desta pesquisa sobre o professor se daria e poderia ser observado apenas no nível discursivo ou se sua projeção poderia ser observada também no seu agir.

Assim, constatamos que, já durante o segundo bimestre o professor se dispôs a testar os novos moldes apresentados, o que por si já se constitui em um indício de que a pesquisa não ficaria apenas no discurso do mesmo.

Após terminadas as observações de aula, o professor, por vontade própria, decidiu continuar com modelos e princípios de avaliação formativa no semestre seguinte, sem a presença da pesquisadora, pois segundo ele, seria um retrocesso voltar aos moldes anteriores de avaliação.

Além disso, o professor utilizou-se de sua posição como assistente pedagógico na escola para criar uma orientação permanente e oficial para os novos professores da instituição abordando o tema avaliação sob diversos prismas e perspectivas.

Por fim, o professor tomou a iniciativa de convidar esta pesquisadora para a elaboração de uma segunda sessão de discussão, na qual ele dialogou a respeito da avaliação que está adotando com a sua turma atualmente, a qual 
segue as bases formativas, além de apresentar um discurso mais informado sobre os conceitos avaliativos e as funções básicas da avaliação.

Assim, dadas todas as afirmações acima, acredito ser seguro afirmar que esta pesquisa causou um profundo impacto nas crenças do professor, ocasionando não apenas uma mudança de discurso, mas também uma reavaliação da sua prática.

Feitas as devidas considerações sobre os objetivos e perguntas de pesquisa, passo, a seguir, para as contribuições deste estudo.

\subsection{CONTIBUIÇÕES DO ESTUDO}

Acredito que a maior contribuição teórica deste estudo se encontra no fato dele ter lançado luz sobre o processo de ressignificação de crenças, analisando como a reflexão pode ocasionar impactos grandiosos sobre as crenças, e demonstrando como sessões de visionamento se constituem em instrumentos substanciais para criar a abertura necessária para que o próprio professor enxergue e discuta sobre a sua prática.

Além disso, este estudo promove a avaliação formativa, informando sobre seus princípios e finalidades, além de demonstrá-la de forma prática através das implementações adotadas pelo professor no segundo bimestre de aulas de 2015. A manutenção de um diálogo aberto com os alunos, a divisão de responsabilidades entre docentes e discentes e a adoção de critérios nas avaliações são apenas algumas das questões discutidas e encorajadas neste estudo.

Outra contribuição reside na elaboração das tabelas de critérios para apresentações orais e redações, as quais podem ser utilizadas e adaptadas para contextos avaliativos diversos. As tabelas foram formuladas a partir de leituras de teóricos renomados no que diz respeito à avaliação e podem vir a conferir mais clareza e objetividade nos processos avaliativos. 
Por fim, uma contribuição prática desta pesquisa jaz no fato de, à luz das ideias desenvolvidas com o professor participante, instituiu-se uma nova orientação na escola, a qual se constitui em um espaço para reflexões a respeito da avaliação e, possivelmente, o primeiro passo para que alguns professores comecem a repensar a sua própria prática no que tange à avaliação.

Após elencar as contribuições deste estudo, discorro a seguir sobre os fatores limitantes do mesmo.

\subsection{LIMITAÇÕES DO ESTUDO}

Uma das grandes limitações desta pesquisa diz respeito ao tempo destinado para observação de aulas e momentos reflexivos junto ao professor, uma vez que as observações ocorreram durante um semestre letivo, não permitindo assim a observância mais profunda do processo de ressignificação das crenças e as mudanças de tomada de atitude advindas do mesmo. Uma vez entendida a concepção de que o processo de ressignificação de crenças não é linear, mas sim um caminho de idas e vindas, com tentativas que permitirão a implementação ou refutação de novas possibilidades, acredito que a maior permanência em campo, através, principalmente, das observações de aula, permitiria uma análise mais precisa e detalhada da dinâmica deste processo.

Outra situação que se coloca como limitação deste estudo encontra-se novamente no fator tempo, mas agora em referência à falta tempo para a realização das atividades avaliativas propostas no projeto inicial da pesquisa. Haja vista que o intuito inicial deste estudo era realizar, ao longo do segundo bimestre de aulas de 2015, um plano de portfólio junto ao professor e sua turma, com a previsão de outras atividades avaliativas de cunho formativo, como a autoavaliação, o que se observou na prática foi a impossibilidade de realização do projeto inicial devido ao cronograma apertado da escola para 0 nível observado. 
Por fim, há ainda que se ressaltar como limitação a falta de abertura para a pesquisa por parte dos professores. Como já explicado em capítulos anteriores, a cooperativa que recebeu este estudo se encontra aberta à pesquisa. Entretanto, há uma grande dificuldade em se encontrar docentes dispostos abrir as suas portas e permitir que suas aulas se constituam em objeto de pesquisa. Seja pela quantidade de trabalho que já acumulam, pela falta de confiança nos propósitos das pesquisas - advinda de experiências passadas - ou pelo medo de mudanças, muitos professores que apresentavam o perfil necessário para ser participante desta pesquisa não se sentiram confortáveis perante o convite de participarem deste estudo.

\subsection{SUGESTÕES PARA FUTURAS INVESTIGAÇÕES}

No decorrer da tessitura desta pesquisa, muitos questionamentos se apresentaram, os quais, devido ao tempo, não foram trabalhados. Além disso, os desdobramentos naturais da pesquisa pressupõem diversas outras questões a serem analisadas e que podem dar origem a futuras pesquisas.

Assim, aponto alguns direcionamentos para futuros estudos:

- Pesquisas que observem as crenças dos alunos no tocante à avaliação e como estas se traduzem em atitudes no processo de aprender uma nova língua;

- Pesquisas que observem a influência das crenças dos alunos no que concerne à avaliação sobre as crenças dos professores e suas atitudes em sala de aula;

- Pesquisas que trabalhem com a influência da utilização de critérios e portfólios na avaliação dos alunos;

- Pesquisas que elaborem critérios básicos de avaliação para serem utilizados como modelos nos currículos escolares de cursos de LE.

- Pesquisas longitudinais que demonstrem o processo de ressignificação ou de manutenção de crenças de forma mais detalhada e precisa. 
Uma vez apresentados temas que carecem de mais atenção e podem inspirar pesquisadores, esboço na seção seguinte as últimas considerações a respeito deste estudo.

\subsection{PALAVRAS CONCLUSIVAS}

Para finalizar este trabalho, entendo ser importante revelar que a inquietação ocasionada pela pesquisa surgiu primeiramente em mim, uma vez que antes deste estudo eu mesma praticava e difundia técnicas e modelos de avaliação não fundamentados, sem ponderações ou reflexões sobre os mesmos, de forma que eles pouco contribuíam para a formação dos meus alunos.

Percebi também que muitas vezes nós, professores, vislumbramos nos alunos crenças que são nossas, acreditando que eles compartilham dos nossos medos, anseios e verdades, sem dar-Ihes voz para expressar a forma pela qual enxergam 0 processo de ensino/aprendizagem. Destarte, perpetuamos pensamentos e ações sem dar ao outro a possibilidade do diferente, do novo, porque nós mesmos não nos permitimos conhecê-los.

Portanto, entendi que momentos como os proporcionados por esta pesquisa, os quais oportunizam a reflexão, constituem-se, ao meu ver, em grandes aliados no processo de ressignificação de crenças e, consequentemente, na transformação do que se entende hoje em dia como avaliação. 


\section{REFERÊNCIAS}

ALANEN, R. A sociocultural approach to young language learners' beliefs about language learning. In: KALAJA, P.; BARCELOS, A. (Eds.). Beliefs about SLA: New research approaches. Netherlands: Kluwer Academic Publishers. 2003.

ALMEIDA FILHO, J. C. P. de. A cultura de aprender. Campinas: UNICAMP, 1993.

O professor de língua estrangeira em formação. Campinas: Pontes, 2005.

O Ensino de Línguas no Brasil de 1978: e agora? Revista brasileira de Linguistica Aplicada, v.1, n.1, p. 15-29, 2001.

. Linguística Aplicada, Ensino de Línguas e

Comunicação. Campinas: Pontes, 2007.

ANDRE, M. E. D. A. Etnografia da Prática Escolar. Papirus, Campinas, n. 15, 2008.

ARAÚJO, Denise Rodrigues de. Crenças de professores de inglês de escolas públicas sobre o papel do bom aprendiz: um estudo de caso. Dissertação de Mestrado. Programa de Pós-graduação em Lingüística Aplicada, FALE - UFMG/Belo Horizonte, 2004.

O processo de reconstrução de crenças e práticas pedagógicas de professores de inglês (LE): foco no conceito de autonomia na aprendizagem de línguas. In: BARCELOS, A. M. F.; VIEIRA ABRAHÃO, M. H. (Orgs.). Crenças e ensino de línguas: foco no professor, no aluno e na formação de professores. Campinas, Pontes, 2006, p. 189-202.

ARRUDA, C. F. B. O processo de ressignificação de crenças e de mudança na prática pedagógica de um professor de Inglês em educação continuada. Dissertação (Mestrado em Estudos Linguísticos). Belo Horizonte: UFMG, 2008.

AVILA, A. P. Crenças e reflexão de professores sobre a avaliação de aprendizagem no ensino instrumental de línguas estrangeiras. 
Dissertação (Mestrado em Estudos Linguísticos). Centro de Artes e Letras, Santa Maria: RS, 2013.

BAFFI-BONVINO, Melissa A. Avaliação da proficiência oral em inglês como língua estrangeira de formandos em letras: uma proposta para validar o descritor 'vocabulário' de um teste de professores de língua inglesa. Tese (Doutorado em Estudos Linguísticos) - Instituto de Biociências, Letras e Ciências Exatas, UNESP, São José do Rio Preto, 2010.

BANDEIRA, G.M. Por que ensino como ensino? A manifestação e atribuição de origem de teorias informais no ensinar de professores de LE (Inglês). Dissertação (Mestrado em Linguística Aplicada), Instituto de Letras, Universidade de Brasília, 2003.

BARATA, M. C. C. M. Crenças sobre avaliação em Língua Inglesa: Um estudo de caso a partir das metáforas no discurso de professores em formação. Tese de doutorado em Linguística Aplicada. UFMG, Belo Horizonte, 2006.

BARCELOS, Ana Maria F. A cultura de aprender língua estrangeira (inglês) de alunos de Letras. Campinas, Unicamp, Instituto de Estudos da Linguagem, Dissertação (Mestrado em Linguística Aplicada), 1995. .Crenças sobre aprendizagem de línguas, Lingüística Aplicada e ensino de línguas. Linguagem \& Ensino, v. 7, n. 1 , p.123-156, 2004.

Understanding teachers' and students' language learning beliefs in experience: a Deweyan approach. Tese (Doutorado em ensino de inglês como segunda língua). College of Education, The University of Alabama, Tuscaloosa, 2000.

Metodologia de pesquisa das crenças sobre aprendizagem de línguas: estado da arte. Revista Brasileira de Linguística Aplicada, v. 1, n. 1, p. 71-92, 2001.

.Cognição de professores e alunos: tendências recentes na pesquisa decrenças sobre 0 ensino e aprendizagem de línguas. In: BARCELOS, A. M. F.; ABRAHÃO, M. H. V. (Orgs.). Crenças e ensino de línguas: foco no professor, no aluno e na formação de professores. Campinas: Pontes, p. 15-42, 2006. 
Reflexões acerca da mudança de crenças sobre ensino e aprendizagem de línguas. Revista Brasileira de Linguística Aplicada. ALAB - Associação de Linguística Aplicada do Brasil. Belo Horizonte, v. 7, n. 2. p. 109-38, 2007.

BARCELOS, A. M. F.; VIEIRA-ABRAHÃO, M. H. Crenças e Ensino de Línguas: Foco no professor, no aluno e na formação de professores. Campinas, SP: Pontes Editores, 2006.

BATISTA, Luís O. Crenças de professores recém formados sobre a avaliação em língua estrangeira (inglês): da elicitação à conscientização. Horizontes de Linguística Aplicada, ano 12, n.1, p. 95-113, 2013.

BAUER, M. W.; AARTS, B. A construção do corpus: um princípio para a coleta de dados qualitativos. In: BAUER, M. W.; GASKEL, G. (Eds.). Pesquisa qualitativa com texto, imagem e som: um manual prático. Petrópolis, RJ: Vozes, 2002.

BELAM, P. V. A interação entre as culturas de avaliar de uma professora de LE (Inglês) e de seus alunos do curso de Letras no contexto de uma universidade particular. Dissertação (Mestrado em Estudos Lingüísticos) - Instituto de Biociências, Letras e Ciências Exatas, Universidade Estadual Paulista, São José do Rio Preto. 2004.

BLATYTA, D. F. Mudança de habitus e teorias implícitas - uma relação dialógica no processo de educação continuada de professores. In: ALMEIDA FILHO, J.C.P. (Org.) O Professor de Língua Estrangeira em Formação. Campinas: Pontes Editores, 1999. p. 63-81.

BOGDAN, R. C.; BIKLEN, S. K. Qualitative research for education: an introduction to theory and methods. Needham Heights, MA: Allyn; Bacon, 1998.

BOMFIM, Bernadette B.S.B.; CONCEIÇÃO, Mariney P. Crenças de aprendizagem de línguas e a formação reflexiva do professor. Revista Horizontes de Lingüística Aplicada, v. 8, n. 1, p. 54-67, 2009.

BORG, S. Teacher cognition in language teaching: A review of research on what teachers think, know, believe and do. Language Teacher, v. 36, p.81-109, 2003.

BOURDIEU, Pierre. A Dominação Masculina Rio de Janeiro. Editora Bertrand Brasil, 2003. 
BRASIL. Ministério da Educação. Parâmetros curriculares Nacionais. Brasília: MEC, 1998.

CHIZZOTTI, A. Pesquisa qualitativa em ciências humanas e sociais. Petrópolis, RJ: Vozes, 2006.

CLANDININ, J. D.; CONNELLY, F. M. Narrative Inquiry: experience and story in qualitative research. San Francisco: Jossey-Bass, 2000.

CONCEIÇÃO, M. P. Vocabulário e consulta ao dicionário: analisando as relações entre experiências, crenças e ações na aprendizagem de LE. Brasil, 2004. Tese (Doutorado em Linguística Aplicada) - Faculdade de Letras, Universidade de Minas Gerais, Belo Horizonte, 2004.

DEMO, P. A avaliação sobre o olhar propedêutico. 6. ed. São Paulo: Papirus, 2005.

DENZIN, N. K.; LINCOLN, Y. S. Introdução: a disciplina e a prática da pesquisa qualitativa. In: DENZIN, N. K.; LINCOLN, Y. S. (Ogs.). O planejamento da pesquisa qualitativa: teorias e abordagens. Porto Alegre: Artmed, 2006. p. 15-44.

DUFF, P. A. Case Study Research in Applied Linguistics. New York: Lawrence Erlbaum , 2008.

DUTRA, D. P.; MELLO, H. A prática reflexiva na formação inicial e continuada de professores de Língua Inglesa. In: VIEIRA ABRAHÃO, M. H. (Org.) Prática de Ensino de Língua Estrangeira: Experiências e reflexões. Campinas: Pontes Editores, Arte Língua, 2004. p.31-43.

ELLIS, R. The Study of Second Language Acquisition. Oxford: Oxford University Press, 1994.

FAIN-FERREIRA, A. L. Crenças sobre o conceito e o papel da avaliação no ensino de Língua Estrangeira em um context de formação inicial: um estudo de caso. Dissertação (Mestrado) - Programa de Pós-Graduação em Letras, da Universidade Federal de Santa Maria, RS, 2005.

FALTIS, C. Case Study methods in researching language and education. In: HORNBERGER, N.; CORSON, D. (Eds.). Research Methods in language and education. Encyclopedia of Language and Education. v. 8 Dordrecht: Kluwer Academic Publishers, 1997. p. 145-152.

FERREIRA, L. M. S. Retratos da Avaliação: Conflitos, desvirtuamentos e caminhos para a superação. Porto Alegre: Mediação, 2009. 
FETTERMAN, D. M. Ethnography: step by step. London: Sage, 1998.

FREEBODY, P. Qualitative research in education: interaction and practice. London: Sage, 2003.

FREIRE, P. Pedagogia do Oprimido. $17^{\circ}$ ed. Rio de Janeiro, Paz e Terra, 1987.

Pedagogia da autonomia: saberes necessários à prática educativa / Paulo Freire. - São Paulo: Paz e Terra, 1996. - (Coleção leitura).

FIDALGO, S.S. A avaliação na escola: um histórico de exclusão social-escolar ou uma proposta sociocultural para a inclusão? Revista Brasileira de Linguística Aplicada. Belo Horizonte, v. 6, n. 2, p. 15-31, 2006.

FLICK, U. Uma introdução à pesquisa qualitativa. Porto Alegre: Bookman, 2004.

FREEMAN, D. Redefining the relationship between research and what teachers know. In K. M. BAILEY; D. NUNAN (Eds.), Voices from the classroom. Cambridge: Cambridge University Press, 1996. p. 88-115.

FREEMAN, D.; RICHARDS, J.C. Teacher Learning in Language Teaching. Cambridge: Cambridge University Press, 1996.

GARDNER, R. C. The socio-educational model of second-language learning: assumptions, finding, and issues. Language learning, 38 (1), p. 101-126, 1988.

GATTI, B. A. (Org.). 0 trabalho docente: avaliação, valorização, controvérsias. Campinas: Autores Associados, 2013.

GERGEN M. M.; GERGEN K. J. Investigação qualitativa: tensões e transformações. In DENZIN, N. K.; LINCOLN, Y. S.(orgs.). O planejamento da pesquisa qualitativa: teorias e abordagens. Porto Alegre: Artmed, 2006. pp. 367-388.

GERMAIN, C. Evolution de l'enseignement des langues: 5000 ans d'histoire. Paris: Clé International,1993. (Col. Didactique des langues étrangères).

GÓMEZ, A. P. O pensamento prático do professor. In: NÓVOA, A. (Coord.). Os professores e a sua formação. Lisboa: Publicações Dom Quixote, 1992. p.93-114.

HALLIDAY, M. A . K et alii. As ciências lingüísticas e o ensino das línguas. Petrópolis: Vozes, 1974. 
HOFFMANN, J. M. L. Avaliação mediadora: uma prática em construção da pré-escola à universidade. Porto Alegre: Editora Mediação, 1993.

Avaliação, mito \& desafio: Uma perspectiva construtivista. 26 ed. Porto Alegre: Editora Mediação, 1999. 128 p.

HORWITZ, E. K. Meeting the cognitive and emotional needs of new foreign language teachers. In Z. MOORE (Ed.), Foreign language teachers education: Multiple perspectives. New York: University Press of America, 1996. p. 289-199.

JOHNSON, D. M. Approaches to research in Second Language Learning. New York, Longman, 1992.

JOHNSON, K.E. The emerging beliefs and instructional practices of preservice English as a second language teachers. Training and Teacher Education, v.10, n. 4, p. 439-452, 1994.

KALAJA, P. Student beliefs (or metacognitive knowledge) about SLA reconsidered. International Journal of Applied Linguistics, v.5, n.2, p. 191204, 1995.

KUDIESS, E. As crenças e os sistemas de crenças do professor de Inglês sobre o ensino e a aprendizagem da língua estrangeira no sul do Brasil: sistemas, origens e mudanças. Universidade de Barcelona, Espanha. Linguagem \& Ensino, Vol. 8, No. 2, 2005. p.39-96.

LAVILLE, C.; DIONNE, J. A. A construção do saber: Manual de metodologia da pesquisa em ciência humanas. Porto Alegre: Armed / Belo Horizonte: Editora da UFMG, 1999.

LIBÂNEO, José Carlos. Didática. São Paulo. Cortez, 1994.

LOPES, J. \& SILVA, H. S. 50 Técnicas de avaliação formativa. Porto: Lidel, 2012.

LUCKESI, Cipriano Carlos. Avaliação da Aprendizagem Escolar: estudos e proposições. $7^{\mathrm{a}}$ ed. São Paulo: Cortez, 1998.

Avaliação da aprendizagem escolar. São Paulo:

Cortez, 2001/2005.

LUNENBURG, F. \& SCHMIDT, L. Pupil control ideology, pupil control behavior and quality of school life. Journal of Research and Development in Education n.22, p.35-44, 1989. 
MASTRELLA, M.R. A relação entre crenças dos aprendizes e ansiedade em sala de aula de língua inglesa: um estudo de caso. Brasil, 2002. Dissertação (Mestrado em Letras) - Faculdade de Letras. Universidade Federal de Goiás, Goiânia, 2002.

MERRIAM, Sharan B. Case study research in education: a qualitative approach. San Francisco: Jossey-Bay Publishers, 1988.

Qualitative research and case study applications in education. San Francisco: Jossey-Bay Publishers, 1998.

MESQUITA, A. A. F. Crenças e práticas de avaliação no processo interativo e na mediação de um par no tandem à distância: Um estudo de caso. 2008. Dissertação (Mestrado em Estudos Linguísticos). São José do Rio Preto: UNESP/IBILCE, 2008.

MICCOLI, L. Experiências, crenças e ações: uma relação estreita na sala de aula de LE. In: SILVA, K. A. da. (Org.). Crenças, discursos e linguagem - volume 1. 1. ed., Campinas-São Paulo: Pontes editores, 2010. p. 135-165.

MOURA FILHO, Augusto César Luitgards. Reinventando a aula: Por um contexto cooperativo para a aprendizagem de inglês como língua estrangeira. Brasília, 2000, 161 p. Dissertação (Mestrado em Linguística) - Departamento de Línguistica, Línguas Clássicas e Vernáculas, Universidade de Brasília, 2000.

MUKAI, Y.; CONCEIÇÃO, M. P. Aprendendo Língua Japonesa: crenças, ações e reflexões de uma aluna brasileira de japonês como língua estrangeira. In.: MUKAI, Y.; JOKO, A. T.; PEREIRA, F. P. (Orgs.). A língua japonesa no Brasil: reflexões e experiências de ensino e aprendizagem / Coleção Japão em Foco Campinas-SP: Pontes Editores, 2012. p. 111-154.

NÓVOA, Antônio (org). Os Professores e a sua Formação. Lisboa: Publicações Dom Quixote, 1995.

NUNAN, D. Research Methods in Language Learning. Cambridge: Cambridge University Press, 1992.

Seven hypotheses about language teaching and learning. TESOL Matters, v.10, n.2, 2000.

PAIVA, V.L.M.O. A www e o ensino de Inglês. 2001. Disponível em: 
<http://www.veramenezes.com/www.htm> Acesso em 10 de Janeiro de 2015.

PAIVA, V. L. M. O. Linguagem, gênero e aprendizagem de língua inglesa. In: ALVAREZ, M. L. O; SILVA, K. A. Linguística Aplicada: múltiplos olhares. Campinas: Pontes Editores, 2007.

PAJARES, F. M. Teachers' beliefs and educational research: Cleaning up a messy construct. Review of Educational Research, v.62, n.3, p. 307-332. 1992.

PORTO, C. V. Percepções de Professores de letras/inglês sobre avaliação de aprendizagem: um estudo de caso. Dissertação (Mestrado em Linguística Aplicada) - Faculdade de Letras, UFMG, Belo Horizonte, MG, 2003.

POSNER, G.J., STRIKE, K.A., HEWSON, P.W. \& GERTZOG, W.A. Accommodation of a scientific conception; Toward a theory of conceptual change. Science Education n.66, p.211-227, 1982.

PUNCH, M. Politics and ethics in qualitative research. In DENZIN, N. K. \& LINCOLN, Y. S. (Eds.). Handbook of qualitative research. London: Sage, 1994. p. $516-529$.

ROLIM, A. C. O. A cultura de avaliar de professoras de língua estrangeira (inglês) no contexto da escola pública. Dissertação (Mestrado em Linguística Aplicada) - Instituto de Estudos da Linguagem, UNICAMP, Campinas. 1998.

A cultura de avaliar de professoras de língua estrangeira (inglês) no contexto da escola pública. In: ROTTAVAL, L.; LIMA, M. S. (Orgs.). Linguística Aplicada: relacionando teoria e prática no ensino de línguas. ljuí: Unijuí, 2004. p.139-163.

ROMÃO, J. E. Avaliação dialógica: desafios e perspectivas. 5. ed. São Paulo: Cortez, 2003.

ROSA, M. V. F. P. C.; ARNOLDI, M. A. G. C. A entrevista na pesquisa qualitativa. Belo Horizonte: Autêntica, 2006.

SANTOS, L. L. F. Análise de provas elaboradas por professores em formação: um estudo de caso. Dissertação de mestrado em Estudos Lingüísticos. UFMG, Belo Horizonte, 2001. 
SANTOS, Sulany. S. (Orgs.). Ensino e aprendizagem de línguas: língua estrangeira. ljuí: Editora ljuí, 2006. p. 49-64.

SAVIANI, Demerval. Educação: do senso comum à Consciência Filosófica. São Paulo: Autores Associados, 2000.

SCARAMUCCI, M. R. V. Avaliação: mecanismo propulsor de mudanças no ensino/aprendizagem de língua estrangeira. Contexturas v. 4, APLIESP, p. $114-124,1998 / 1999$.

Avaliação de rendimento no ensinoaprendizagem de português língua estrangeira. In: ALMEIDA FILHO, J. C. P. (Org.) Parâmetros atuais para o ensino de português língua estrangeira. Campinas: Pontes, 1997. p. 75-88.

Efeito retroativo da avaliação no ensino/aprendizagem de línguas: o estado da arte. Trabalhos em Linguística Aplicada, vol. 43, n.2, p. 203-226, 2004.

- O professor avaliador: sobre a importância da avaliação na formação do professor de língua estrangeira. In: ROTTAVA, L.; SANTOS, S. S. (Orgs.). Ensino e Aprendizagem de Línguas Língua Estrangeira. Editora Unijuí, p. 47 - 64. 2006. . Validade e consequências sociais da avaliação

de desempenho no contexto de línguas. Campinas, SP. Projeto de pós doutorado, FAPESP, 19, p. 2007.

SCHMIDT, L.; JACOBSON, M. Pupil control in the school climate. (ERIC Document Reproduction Service No. ED319692), 1990.

SCHWANDT, T. A. Três posturas epistemológicas para a investigação qualitativa. In: DENZIN, N. K.; LINCOLN, Y. S. (Orgs.). O planejamento da pesquisa qualitativa: teorias e abordagens. Porto Alegre: Artmed, 2006, p.193-217.

SERAFINI, M.T. Como escrever textos. 6. ed. São Paulo: Globo, 2001.

SHHOFFEN, J.R. Avaliação de proficiência oral em língua estrangeira: descrição dos níveis de candidatos falantes de espanhol no exame CelpeBras. 2003. Dissertação de Mestrado - Universidade Federal do Rio Grande do Sul.

SILVA, K. A. Crenças e aglomerados de crenças de alunos ingressantes em Letras (Inglês), 2005, 243 f. Dissertação (Mestrado em Lingüística 
Aplicada) - Instituto de Estudos da Linguagem, Universidade Estadual de Campinas, Campinas.

SILVA, Kleber A.; ROCHA, Claudia H.; SANDEI, Maria L. R. A importância do estudo das crenças na formação de professores de línguas. Contexturas, n. 8, p. 19-40, 2005.

SILVEIRA, R. M. H. A entrevista na pesquisa em educação: uma arena de significados. In: COSATA, M. V. (Org.). Caminhos investigativos II: outros modos de fazer pesquisa em educação. Rio de Janeiro: DP\&A, 2002.

SCHÜKLENK, U. Ética na pesquisa: experiência de treinamento em países sul-africanos. In DINIZ, D., GUILHEM, D.; SCHÜKLENK, U. (Eds.). Brasília: Editora da UnB, 2005.

SUASSUNA, L. BEZERRA, M. B. Avaliação da produção escrita e desenvolvimento de sequências didáticas. Est. Aval. Educ., São Paulo, v. 21, n. 47, p. 611-628, set./dez. 2010.

VAN LIER, L. The classroom and the language learner: Ethnography and second language classroom research. London: Longman, 1988.

VIEIRA-ABRAHÃO, M. H. Metodologia na investigação das Crenças. In BARCELOS, A. M. F.; VIEIRA-ABRAHÃO, M. H. (Orgs.). Crenças e Ensino de Línguas: Foco no professor, no aluno e na formação de professores. Campinas, SP: Pontes Editores, 2006.

- Crenças, pressupostos e conhecimentos de alunos-professores de língua estrangeira e sua formação inicial. In: VIEIRA-ABRAHÃO, M. H. (Org.). Prática de ensino de língua estrangeira: experiências e reflexões. Campinas-São Paulo: Pontes Editores, ArtLíngua, 2004.p.131-152.

Wiersma, W. (1995). Research methods in education: An introduction (Sixth edition). Boston: Allyn and Bacon.

WOODS, Devon. The social construction of beliefs in the language classroom. In: KALAJA, P.; BARCELOS, Ana Maria F. (Orgs.). Beliefs about SLA: new research approaches. Dordrecht: Kluwer, 2003. p. 201-227.

ZOCARATTO, B. L. A Cultura De Avaliar De Professores De Inglês Em Formação Inicial De Um Curso De Letras De Uma Universidade Do Df: Estudo De Caso. Dissertação (Mestrado em Linguística Aplicada) - 
Programa de Pós-Graduação em Linguística Aplicada do Departamento de Línguas Estrangeiras e Tradução, UnB, Brasília. 2010. 


\section{APÊNDICE A}

\section{UNIVERSIDADE DE BRASÍLIA \\ INSTITUTO DE LETRAS \\ DEPARTAMENTO DE LÍNGUAS ESTRANGEIRAS E TRADUÇÃO \\ PROGRAMA DE PÓSGRADUAÇÃO EM LINGUSTICA APLICADA \\ Pesquisadora: Thalita da Rocha Soares Ferreira \\ Orientador: Prof. Dr. Yuki Mukai}

\section{TERMO DE CONSENTIMENTO}

Prezado Coordenador,

Com o intuito de elaborar a minha dissertação de Mestrado em Linguística Aplicada da Universidade de Brasília, gostaria de solicitar a sua autorização para a realização da pesquisa sobre crenças de professores em serviço na unidade de ensino da COOPLEM Idiomas na qual você é o coordenador.

A coleta de registros, em sala de aula, será realizada através da observação das aulas de um dos professores de língua inglesa desta unidade, durante todo 0 primeiro semestre letivo de 2015. As aulas serão gravadas em áudio e vídeo e notas de campo serão realizadas pela pesquisadora para futura triangulação de dados.

Você e o professor terão acesso aos resultados antes de serem publicados e terão oportunidades de refletir com a pesquisadora sobre os dados, manifestando opiniões ou sugerindo modificações.

Cumpre ainda reiterar que a sua colaboração é de natureza voluntária, sem nenhuma coerção e que sua identidade será mantida em total sigilo, caso assim você deseje e solicite, ao longo e após a finalização da pesquisa.

Desde já agradeço a sua colaboração.

Assim sendo, declaro que fui informado sobre os procedimentos utilizados e entendo qual será a minha colaboração como participante desta pesquisa.

Recebi uma cópia deste termo de consentimento.

Coordenador Administrativo

Brasília, 21 de Fevereiro de 2015.

Thalita da Rocha Ferreira

(thalitasilva@yahoo.com.br) 


\title{
APÊNDICE B
}

\author{
UNIVERSIDADE DE BRASÍLIA \\ INSTITUTO DE LETRAS \\ DEPARTAMENTO DE LÍNGUAS ESTRANGEIRAS E TRADUÇÃO \\ PROGRAMA DE PÓSGRADUAÇÃO EM LINGUSTICA APLICADA \\ Pesquisadora: Thalita da Rocha Soares Ferreira \\ Orientador: Prof. Dr. Yuki Mukai
}

\section{TERMO DE CONSENTIMENTO}

Prezado Professor,

Com o intuito de elaborar a minha dissertação de Mestrado em Linguística Aplicada da Universidade de Brasília, gostaria de solicitar a sua autorização para a realização da pesquisa sobre crenças de professores em serviço.

Haja vista a importância do seu papel nesta pesquisa, solicito, também, a sua cooperação como participante na coleta de registros e análise de dados, por meio de questionário, narrativa escrita, entrevista semiestruturada, leitura de textos base e sessões de visionamento.

Cumpre ainda reiterar que:

- a sua participação é de natureza voluntária, sem nenhuma coerção;

- você pode, em qualquer momento, desistir de participar da pesquisa;

- sua identidade será mantida em total sigilo, caso assim você deseje e solicite, ao longo e após a finalização da pesquisa.

- suas respostas poderão ser utilizadas na dissertação, relatório e eventuais artigos ou apresentações sobre o estudo;

- todas as aulas observadas serão gravadas em áudio, e, algumas, a serem selecionadas pela pesquisadora, serão também gravadas em vídeo.

- será necessária a leitura de alguns textos básicos, no decorrer da pesquisa, para futuras discursões nas sessões de visionamento, os quais serão disponibilizados pela pesquisadora.

Desde já agradeço a sua colaboração para o sucesso da presente pesquisa.

Assim sendo, declaro que fui informado sobre os procedimentos utilizados e entendo qual será a minha colaboração como participante desta pesquisa.

Recebi uma cópia deste termo de consentimento.

\section{Professor}

Brasília, 21 de Fevereiro de 2015.

Thalita da Rocha Ferreira (thalitasilva@yahoo.com.br) 


\title{
APÊNDICE C
}

\author{
UNIVERSIDADE DE BRASÍLIA \\ INSTITUTO DE LETRAS \\ DEPARTAMENTO DE LÍNGUAS ESTRANGEIRAS E TRADUÇÃO \\ PROGRAMA DE PÓSGRADUAÇÃO EM LINGUSTICA APLICADA \\ Pesquisadora: Thalita da Rocha Soares Ferreira \\ Orientador: Prof. Dr. Yuki Mukai
}

\section{TERMO DE CONSENTIMENTO}

\section{Prezado Aluno(a),}

Com o intuito de elaborar a minha dissertação de Mestrado em Linguística Aplicada da Universidade de Brasília, gostaria de solicitar a sua autorização para a realização da pesquisa sobre crenças de professores em serviço.

Esclareço que a pesquisa será realizada a respeito das crenças do professor, e não dos alunos. Entretanto, como as observações serão feitas na sala de aula em que você estuda, sua colaboração, apesar de não obrigatória, será de grande valia para o sucesso deste estudo que busca trazer contribuições para a área de ensino e aprendizagem de inglês como língua estrangeira.

Cumpre ainda reiterar que:

- a sua participação é de natureza voluntária, sem nenhuma coerção;

- sua identidade será mantida em total sigilo, ao longo e após a finalização da pesquisa.

- suas respostas poderão ser utilizadas na dissertação, relatório e eventuais artigos ou apresentações sobre o estudo, utilizando-se pseudônimos pré-estabelecidos;

- todas as aulas observadas serão gravadas em áudio, e, algumas, a serem selecionadas pela pesquisadora, serão também gravadas em vídeo.

Desde já agradeço a sua colaboração.

Assim sendo, declaro que fui informado sobre os procedimentos utilizados e entendo qual será a minha colaboração como participante.

Recebi uma cópia deste termo de consentimento.

Aluno(a)

Brasília, 21 de Fevereiro de 2015.

Thalita da Rocha Ferreira (thalitasilva@yahoo.com.br) 


\title{
APÊNDICE D
}

\author{
UNIVERSIDADE DE BRASÍLIA \\ INSTITUTO DE LETRAS \\ DEPARTAMENTO DE LÍNGUAS ESTRANGEIRAS E TRADUÇÃO \\ PROGRAMA DE PÓSGRADUAÇÃO EM LINGUSTICA APLICADA \\ Pesquisadora: Thalita da Rocha Soares Ferreira \\ Orientador: Prof. Dr. Yuki Mukai
}

\section{ROTEIRO PARA ENTREVISTA SEMI-ESTRUTURADA}

1. Ao longo de sua formação acadêmica (cursos de inglês, faculdade...), o que foi mais valorizado pelos seus professores: $O$ conteúdo, a forma como ensiná-lo ou ambos?

2. Para você, o que significa ensinar uma língua estrangeira, neste caso, o inglês?

3. O que você considera ser um bom professor de língua inglesa?

4. Qual a melhor forma de ensinar vocabulário?

5. Qual a melhor forma de ensinar gramática?

6. Como um aluno aprende em sala de aula?

7. Como checar se o aluno realmente aprendeu?

8. Pra você, quais são os principais fatores que influenciam a aprendizagem de uma língua estrangeira?

9. Qual é o papel do professor no processo de ensino-aprendizagem?

10. Qual é o papel do aluno neste mesmo processo?

11. Qual é o papel da avaliação no processo de ensino-aprendizagem?

12. Como você geralmente avalia os seus alunos?

13. Quais são os aspectos sob os quais você se sente mais seguro quando ministrando aulas?

14. E em relação a quais você se sente inseguro ou despreparado, caso haja algum?

15. Você já fez algum curso de reciclagem/formação continuada para professores após a conclusão do ensino superior? Quais? Como eles influenciaram a sua maneira de enxergar sua prática docente? 